\author{
Universidade de São Paulo \\ Faculdade de Medicina de Ribeirão Preto \\ Departamento de Medicina Social
}

MARIANA DE OLIVEIRA PASQUALIN RIBEIRO

Recursos e necessidades de profissionais da Estratégia Saúde da Família para lidar com questões relacionadas à Saúde Mental

RIBEIRÃO PRETO 
MARIANA DE OLIVEIRA PASQUALIN RIBEIRO

\section{Recursos e necessidades de profissionais da Estratégia Saúde da Família para lidar com questões relacionadas à Saúde Mental}

Dissertação apresentada ao Departamento de Medicina Social da Faculdade de Medicina de Ribeirão Preto - FMRP - USP para a obtenção de título de Mestre.

Área de concentração: Saúde na Comunidade

Orientadora: Profa. Dra. Maria do Carmo Gullaci Guimarães Caccia-Bava

RIBEIRÃO PRETO 
Autorizo a reprodução e divulgação total ou parcial deste trabalho, por qualquer meio convencional ou eletrônico, para fins de estudo e pesquisa, desde que citada a fonte.

\section{FICHA CATALOGRÁFICA}

Ribeiro, Mariana de Oliveira Pasqualin

Recursos e Necessidades de profissionais da Estratégia Saúde da Família para lidar com questões relacionadas à Saúde Mental. Ribeirão Preto, 2011.

98p. : il. ; $30 \mathrm{~cm}$

Dissertação (Mestrado) apresentada à Faculdade de Medicina de Ribeirão Preto/USP - Área de concentração: Saúde na Comunidade.

Orientadora: Profa. Dra. Maria do Carmo Gullaci Guimarães Caccia-Bava

1. Estratégia Saúde da Família. 2. Saúde Mental. 3. Construção de Sentidos. 
Mariana de Oliveira Pasqualin Ribeiro

Recursos e Necessidades de profissionais da Estratégia Saúde da Família para lidar com questões relacionadas à Saúde Mental.

Dissertação apresentada à Faculdade de Medicina de Ribeirão Preto da Universidade de São Paulo para obtenção do Título de Mestre.

Área de Concentração: Saúde da Comunidade.

Aprovado em:

Banca Examinadora

Profa. Dra. Maria do Carmo Guimarães Caccia-Bava

Instituição: Faculdade de Medicina de Ribeirão Preto-USP

Assinatura:

Profa. Dra. Carla Guanaes Lorenzi

Instituição: Faculdade de Filosofia, Ciências e Letras de Ribeirão Preto-USP

Assinatura:

Profa. Dra. Diva Maria Faleiros Camargo Moreno

Instituição: Faculdade de Saúde Pública - FSP

Assinatura: 


\section{DEDICATÓRIA}

Aos meus pais, Luiz e Marisa.

Pelo amor e carinho incondicionais.

Pelo exemplo de casal, pais e profissionais.

Pelo incentivo para que eu trilhasse meu caminho e lutasse pelos meus sonhos.

Ao Júlio, meu amado companheiro.

Com quem tenho compartilhado muitos sonhos.

Pelo respeito e admiração à minha trajetória profissional.

Pelo jeito atencioso e simples de demonstrar seu amor. 


\section{AGRADECIMENTOS}

À Deus, pelo amparo e proteção durante o percurso deste trabalho.

À minha orientadora, Profa. Dra. Maria do Carmo Gullaci Guimarães Caccia-Bava, pela forma carinhosa e atenciosa com que acompanhou meu caminho durante este trabalho.

À Profa. Dra. Carla Guanaes e Profa. Dra. Diva Maria Faleiros Camargo Moreno, pela seriedade e competência com que analisaram meu trabalho e pelas contribuições sugeridas.

Ao meu pai, pela leitura e interesse em ajudar nesta trajetória, sempre me enriquecendo com seus ensinamentos. À minha mãe, pelo seu jeito acolhedor, presente em todos os momentos, uma mulher em quem me espelho sempre.

À minha irmã, Lívia, grande amiga desde as primeiras descobertas, companheira de várias caminhadas, pelo convívio e amor incondicionais e pelas traduções deste trabalho.

Ao meu irmão, André Luís, pelo carinho e amor sempre demonstrados durante nossa convivência, pelos abraços apertados e pela amizade verdadeira.

Ao Júlio, com quem tenho uma convivência diária de respeito, amizade e carinho. Por me incentivar a vencer os obstáculos e por estar sempre disposto a me ouvir, me aconselhar e me encorajar.

Ao Dr. Paulo e Dona Martha Ribeiro, por terem me recebido em sua família com muito amor e carinho e por serem exemplos de grandes profissionais.

À minha família: avós, tios e primos... Pela convivência afetuosa de sempre, por tornarem minha vida muito mais alegre e completa.

À minha tia e professora, Lúcia Helena, pelas correções no texto e pela disposição e ajuda de sempre.

À todas as minhas amigas, as mais presentes e as que acompanharam este trabalho mais de longe, mas que sempre compartilham comigo momentos de alegria, descontração, boas conversas e a certeza de contar com a amizade, a escuta e o carinho de sempre.

À Profa. Dra. Marisa Japur, pelos férteis encontros para discussão deste trabalho, pela forma carinhosa com que compartilhou seus conhecimentos.

À Secretaria da Saúde de Serra Azul, por ter autorizado a realização deste trabalho.

Aos profissionais das Equipes de Saúde da Família de Serra Azul, participantes deste estudo. Por terem aceitado contribuir com este trabalho, compartilhando suas idéias e experiências.

À CAPES e à FAEPA, pelos auxílios concedidos durante a realização deste estudo. 


\section{RESUMO}

Ribeiro, M. O. P. Recursos e Necessidades de profissionais da Estratégia Saúde da Família para lidar com questões relacionadas à Saúde Mental. 2011. 98f. Dissertação (mestrado) - Faculdade de Medicina de Ribeirão Preto, Universidade de São Paulo, Ribeirão Preto, 2011.

Um dos pilares da política de Atenção Básica do Sistema Único de Saúde (SUS), a Estratégia Saúde da Família (ESF), realiza em equipe, assistência descentralizada nos territórios adscritos e deve conseguir resolver a maioria das demandas em saúde, parte delas advinda da saúde mental. Nesta estratégia, a formação de vínculos positivos e o lidar com o sofrimento humano de forma sistemática representam grandes desafios, que podem ser exacerbados em se tratando de pessoas em sofrimento mental. Foi a partir deste contexto que este trabalho definiu como objetivo produzir sentidos sobre os recursos e necessidades para lidar com questões relacionadas à Saúde Mental com trabalhadores da ESF, do Município de Serra Azul, Estado de São Paulo. O referencial metodológico qualitativo foi utilizado para a análise dos dados a partir do construcionismo social e como instrumento de coleta foi utilizado o recurso do Grupo Focal. Participaram deste estudo os profissionais das duas unidades de saúde da família do Município de Serra Azul. A análise das entrevistas teve início com a transcrição e edição do material gravado. Posteriormente, a pesquisadora realizou uma pré-análise, que consistiu na leitura exaustiva das entrevistas e a imersão em seus conteúdos. Nesta fase, optou-se pela análise de apenas uma das entrevistas realizadas, a que pareceu a mais rica e fértil para os objetivos do presente estudo. A análise (composta pela apresentação dos resultados e da discussão) apontou a construção de sentidos pela equipe de necessidades e recursos existentes no cuidado aos pacientes com problemas de saúde mental. As necessidades descritas foram divididas em três subtemas, que são a falta de estruturas no Município para acolher estes pacientes fora das unidades de saúde, a falta de recursos dos pacientes atendidos e a falta de capacitação e preparo da equipe para este tipo de cuidado. Outro tema apresentado como resultado da análise foi os recursos existentes e não reconhecidos pela equipe para o cuidado a esses pacientes. Foi possível perceber que a criação de espaços de conversa onde estas equipes possam reconhecer seus recursos, trabalhar suas ansiedades e dar novas descrições para suas ações podem contribuir para melhorar o atendimento em saúde mental na Atenção Básica.

Descritores: Estratégia Saúde da Família. Saúde Mental. Construção de sentidos. 


\begin{abstract}
Ribeiro, M. O. P. Resources and Needs of professionals working in the Family Health Strategy to address issues related to Mental Health. 2011. 98p. Thesis (Master's) University of São Paulo at Ribeirão Preto Medical School, Ribeirão Preto, 2011.
\end{abstract}

One of the pillars of the Primary Health Care policy of the Unified Health System (SUS), the Family Health Strategy (FHS), provides decentralized team care in the coverage area and should be able to solve most of the health care needs, some of them related to mental health. In this strategy, the development of positive links and dealing with human suffering in a systematic way represent major challenges, which can be exacerbated when dealing with people in mental distress. In this context, this study aimed to produce meanings about the needs and resources to deal with issues related to Mental Health with workers from the FHS, in the city of Serra Azul, state of São Paulo. Social constructionism was used as qualitative methodological approach, and Focus Group was the data collection tool. Participants were professionals from two family health units of the city of Serra Azul. The data analysis began with transcription and editing of the recorded material. Afterwards the researcher conducted a pre-analysis, which consisted of the careful reading of the interviews and immersion in their content. At this stage, it was chosen to analyze only one of the interviews, which seemed the richest and most fruitful for the purposes of this study. The analysis( consisting of the presentation of results and discussion) pointed out the construction of meanings, by the team, of existing needs and resources in the care of patients with mental health problems. The described needs were divided into three subthemes: the lack of structures in the city to admit these patients other than the health services, lack of resources from patients who are taken care of and the lack of training and preparation of the team for this kind of care. Another theme presented as a result of the analysis was the existing resources that are not recognized by the team for care of these patients. It was possible to notice that the creation of spaces for conversation where these teams can recognize their resources, work on their anxieties and give new descriptions for their actions can contribute to improve mental health care in Primary Care.

Descriptors: Family Health Strategy. Mental Health. Construction of Meaning. 


\section{RESUMEN}

Ribeiro, M. O. P. Recursos y Necesidades de los profesionales de la Estrategia de Salud de la Familia para tratar las cuestiones relacionadas con la Salud Mental. 2011. 98h. Disertación (maestría) - Facultad de Medicina de Ribeirão Preto, Universidad de São Paulo, Ribeirão Preto, 2011.

Uno de los pilares de la política de Atención Primaria del Sistema Único de Salud (SUS), la Estrategia de Salud de la Familia (ESF), realiza en equipo, la atención descentralizada en los territorios del área de cobertura y debe ser capaz de resolver la mayoría de las demandas en salud, algunas de ellas procedentes de la salud mental. En esta estrategia, la formación de vínculos positivos y el tratar el sufrimiento humano de forma sistemática representan grandes desafíos, que pueden ser exacerbados cuando se trata de personas en sufrimiento mental. Fue a partir de este contexto que este estudio tuvo como objetivo producir sentidos de los recursos y necesidades para tratar de las cuestiones relacionadas a la Salud Mental con trabajadores de la ESF, de la ciudad de Serra Azul, estado de São Paulo. Se utilizó el referencial metodológico cualitativo para el análisis de los datos, a partir del construccionismo social, y el Grupo Focal como instrumento de recolecta de datos. Participaron del estudio los profesionales de las dos unidades de salud de la familia de la ciudad de Serra Azul. El análisis de las entrevistas tuvo inicio con la transcripción y edición del material grabado. A continuación la investigadora llevó a cabo un pre-análisis, que consistió en leer detenidamente las entrevistas y la inmersión en sus contenidos. En esta etapa se optó por analizar sólo una de las entrevistas, que parecía la más rica y fértil para los propósitos de este estudio. El análisis (compuesto de la presentación de los resultados y discusión) señaló la construcción de sentidos por el equipo de necesidades y recursos existentes en el cuidado a los pacientes con problemas de salud mental. Las necesidades descritas fueron divididas en tres subtemas, que son la falta de estructuras en la ciudad para acoger a estos pacientes fuera de las unidades de salud, la falta de recursos en los pacientes atendidos y la falta de capacitación y preparación del equipo para este tipo de atención. Otro tema reportado como resultado del análisis fue los recursos existentes y no reconocidos por el equipo para el cuidado a estos pacientes. Fue posible notar que la creación de espacios de conversación en donde estos equipos puedan reconocer a sus recursos, trabajar sus ansiedades y dar nuevas descripciones de sus acciones puede ayudar a mejorar la atención de la salud mental en la Atención Primaria.

Descriptores: Estrategia de Salud de la Familia. Salud Mental. Construcción de sentidos. 


\section{Lista de Abreviaturas e Siglas}

$\mathrm{AB}$ - Atenção Básica

ACS - Agente Comunitário de Saúde

APS - Atenção Primária à Saúde

AT - Acompanhante Terapêutico

CAPS - Centro de Atenção Psicossocial

CNS - Conferência Nacional de Saúde

DRS - Direção Regional de Saúde

ESF - Estratégia Saúde da Família

IAPs - Institutos de Aposentadorias e Pensões

INAMPS - Instituto Nacional de Assistência Médica da Previdência Social

INPS - Instituto Nacional de Previdência Social

MTSM - Movimento dos Trabalhadores em Saúde Mental

NAPS - Núcleos de Atenção Psicossocial

NASF - Núcleo de Apoio a Saúde da Família

OMS - Organização Mundial de Saúde

PACS - Programa de Agentes Comunitários de Saúde

PSF - Programa Saúde da Família

SUS - Sistema Único de Saúde

UBS - Unidade Básica de Saúde

UMS - Unidade Mista de Saúde 


\section{SUMÁRIO}

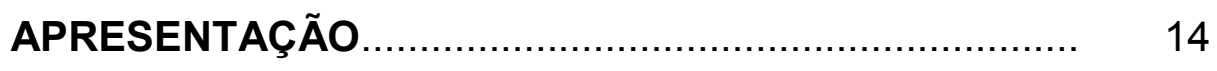

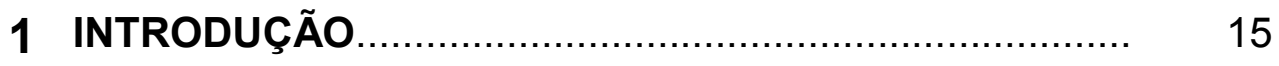

1.1 As Políticas de Saúde e o SUS............................................. 15

1.2 Saúde Mental e Atenção Básica............................................. 19

1.3 A Estratégia Saúde da Família........................................... 26

2 OBJETIVO.............................................................. 31

3 O PERCURSO DO ESTUDO ............................................ 32

3.1 O Referencial Metodológico: contribuições do movimento Construcionismo Social.......................................................... 32

3.20 Contexto .................................................................... 34

3.3 Constituição do "corpus" ..................................................... 35

3.3.1 Instrumento de Investigação............................................... 35

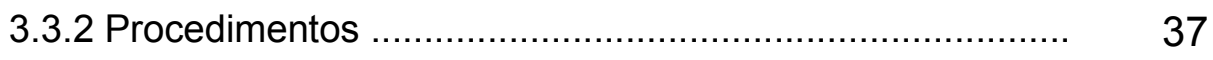

3.3.2.1 Contatos Iniciais .......................................................... 37

3.3.2.2 A Realização das Entrevistas........................................... 38

3.3.2.3 Os Aspectos Éticos........................................................ $\quad 39$

4 ENTREVISTAS REALIZADAS ..................................... 40

4.1 Os Participantes .............................................................. 40

4.1.1 A Equipe Amarela.......................................................... 41

4.1.2 A Equipe Verde ......................................................... 42

4.1.3 A participação da pesquisadora e da orientadora no

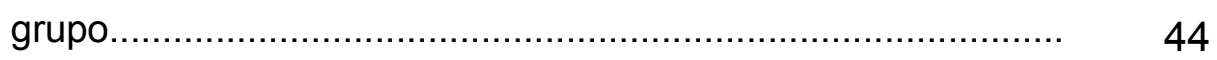

4.2 As Conversas Grupais...................................................... 44

4.2.1 A Equipe Amarela......................................................... 45

4.2.2 A Equipe Verde ........................................................... 45

5 A ANÁLISE DAS ENTREVISTAS.................................... 47

5.1 Transcrição das Entrevistas e Edição do Material............... 47 
6 RESULTADOS: Apresentação e Discussão.................... 50

6.1 O Discurso da Falta.......................................................... 50

6.1.1 “Não tem o que fazer na cidade, o que eles vão fazer?".... 51

6.1.2“Eles não querem se ajudar”............................................ 54

6.1.3“Eu vou surtar”............................................................... 60

6.2 Os Recursos não reconhecidos............................................. 64

7 CONSIDERAÇÕES FINAIS ........................................... 73

REFERÊNCIAS............................................................ 77

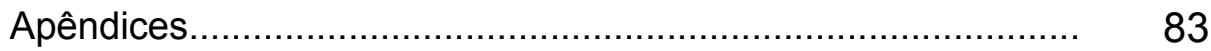






\section{APRESENTAÇÃO}

Foi a prática em saúde mental, como psicóloga de uma Unidade Mista de Saúde (UMS) de Serra Azul- SP, que me motivou a pesquisar o tema do presente estudo. A Saúde Mental figurava como uma das áreas de maior desassistência para os pacientes que a procuravam e parecia estar desvinculada da rede de cuidados do sistema de saúde. O Serviço de Saúde Pública do Município não contava com um psiquiatra em sua equipe de profissionais, o que contribuía para reforçar o lugar periférico que essa área ocupava dentro da rotina de trabalho.

As equipes de saúde pareciam despreparadas para o cuidado a essas pessoas, que eram vistas como pacientes exclusivos da saúde mental, como se não fossem responsabilidade da Atenção Básica $(\mathrm{AB})$.

Comecei a perceber que muitas vezes essa exclusão estava ligada à difículdade dos profissionais em lidarem com este tipo de paciente, que os desafiava a entrar em contato com o sofrimento e a dor psíquica.

Os poucos conhecimentos prévios sobre saúde pública adquiridos durante minha formação, que me permitiram compreender melhor o funcionamento do SUS e a saúde mental dentro deste contexto, despertaram uma necessidade premente de explorar e conhecer melhor esse aspecto da saúde da comunidade.

A equipe de saúde da família, que assiste, cotidianamente, a esses pacientes, e que deveria enxergá-los de forma integral, procurando promover sua saúde e sua (re)inserção na comunidade, acaba não sendo diferente dos outros profissionais da $A B$, encontrando também dificuldades para que este contato se dê de forma integral.

Ter identificado o aumento de encaminhamentos do médico de família e da demanda espontânea ao Serviço de Psicologia me sensibilizou e motivou a buscar entender como as equipes da Estratégia Saúde da Família deste Município lidavam com as questões de Saúde Mental que cotidianamente surgiam no seu contexto de trabalho. Percebi a possibilidade de conhecer a realidade da assistência à Saúde Mental oferecida pelas equipes de saúde da família do Município de Serra Azul, além de oferecer elementos para reflexões e intervenções acerca desta realidade local. 


\section{INTRODUÇÃO}

Este capítulo está organizado em três tópicos que visam contextualizar e embasar teoricamente o tema proposto. O primeiro tópico aborda as políticas de saúde desde o início do século XX, o surgimento do SUS, seu conceito e princípios. O segundo tópico trata da saúde mental e da atenção básica, discorrendo sobre a reforma psiquiátrica e o surgimento das primeiras políticas de Saúde Mental no Brasil. Também são trazidas aproximações desta com a atenção básica em saúde. O terceiro tópico descreve o surgimento da Estratégia Saúde da Família e seu processo de trabalho como um novo modelo de atenção em saúde.

\subsection{As Políticas de Saúde e o SUS}

No Brasil, a Saúde Pública se configurou como política nacional de saúde a partir do início do século $\mathrm{XX}$ com a sistematização das práticas sanitárias, emergindo no contexto sociopolítico do país. Nesta época, marcada por extensos movimentos de imigrações, as mobilizações no campo da Saúde Pública eram focadas no controle da salubridade do ambiente local, por meio de grandes campanhas de vacinação em massa com o objetivo de controlar a eminência de doenças como a febre amarela e a peste (COHN, 1999).

Nas décadas seguintes, de grande desenvolvimento industrial, o foco da Saúde Pública se voltou para a preservação da força de trabalho, o que garantia o crescimento industrial do país. Na década de 30, surgiram os Institutos de Aposentadorias e Pensões (IAPs) que disponibilizavam assistência médica apenas aos seus assegurados, que eram os trabalhadores contribuintes e seus familiares. O Estado pouco participava nas formulações deste programas de assistência à saúde (NUNES, 2000).

Já na década de 60, com a criação do Instituto Nacional de Previdência Social (INPS) e mais tarde, nos anos 70, o Instituto Nacional de Assistência Médica da Previdência Social (INAMPS), apenas os trabalhadores que mantinham vínculo de trabalho formal se beneficiavam de assistência médica desta instituição. Nesta época, a maioria das pessoas dependia dos atendimentos em instituições filantrópicas que ofereciam 
gratuitamente atendimento em leitos hospitalares. Pequena parte da população, com boas condições financeiras, pagava por atendimento privado (CAMPOS, 1988).

Após este período ocorreu o Golpe Militar e novas mudanças foram impostas no setor da saúde, com crescimento do setor privado, endividamento do país e diminuição dos leitos hospitalares filantrópicos e públicos (PAULIN; TURATO, 2004).

Foi esta situação precária da qualidade da assistência à saúde e o acesso restrito da população aos serviços de saúde que deram início ao processo de reforma sanitária. Assim o Movimento Sanitário configurou-se em um cenário de luta por novas concepções do pensar e fazer saúde, com a mobilização de grande parte da sociedade e a proposta de reformulação do Sistema de Saúde Nacional (MATTOS, 2001).

O Movimento, surgido na década de 70, caracterizou-se pela união de profissionais da saúde e de vários setores na tentativa de mostrar os efeitos do sistema econômico vigente sobre as condições de acesso à assistência à saúde da população. Este movimento crítico, além de mostrar os prejuízos deste sistema para a saúde, propunha uma concepção de saúde mais ampla, humanizante e universalizada, que só poderia ser alcançada através de uma ampla reforma sanitária (RODRIGUEZ NETO, 1994).

Nos anos 80 e 90, em um contexto de redemocratização do país, para garantir a saúde da população, impunha-se a constituição de um sistema de saúde inclusivo. A $8^{\text {a }}$ Conferência Nacional de Saúde (CNS), convocada em 1986, lançou os fundamentos da proposta do SUS. A CNS tinha como tema "Democracia é Saúde" e representou um fórum de luta pela descentralização do sistema de saúde (BRASIL, 2006a).

Essas discussões se fortaleciam com o Movimento Sanitário e sustentavam a possibilidade de institucionalização e legalização do SUS.

Com a Constituição Federal de 1988 o SUS ganhou materialidade, colocando a saúde como um direito de todos e dever do Estado. O serviço público de saúde no Brasil passou a organizar-se de forma a buscar trilhar os princípios de universalidade, integralidade e equidade (BRASIL, 1990).

A Constituição reconheceu a relevância pública das ações e serviços de saúde e esboçou um sistema único com a proposta de reorientação do modelo assistencial associando saúde à qualidade de vida. As Leis 8.080/90 e a 8.142/90 são singularmente relevantes para o novo modelo, uma espécie de estatuto da saúde no Brasil. A Lei 8.080/90 sedimenta as orientações constitucionais do SUS e a Lei 8.142/90 trata do envolvimento da comunidade na condução das questões da saúde criando as conferências e os conselhos de 
saúde em cada esfera de governo como instâncias colegiadas orientadoras e deliberativas, respectivamente (PAULUS JR; CORDONI JR, 2006).

O SUS foi responsável pela inclusão de 60 milhões de brasileiros como portadores legais do direito à saúde e apesar de suas dificuldades e imperfeições, antes dele esta grande parcela de brasileiros estava dependente exclusivamente de instituições filantrópicas e de caridade (MENDES, 2001).

Considerando-se que as políticas de saúde surgem no sentido de implementar estratégias governamentais que buscam corrigir os desequilíbrios sociais e reduzir as desigualdades sociais (PESSINI; BARCHIFONTAINE, 2007), justifica-se que os pilares básicos do SUS sejam a universalidade no acesso aos serviços e a promoção da igualdade no atendimento por meio da equidade na distribuição dos recursos.

Sua organização é pautada pelas diretrizes da descentralização e hierarquização com direção única em cada esfera do governo (federal, estadual e municipal), o atendimento integral que vai das atividades preventivas às assistenciais e ao controle exercido pela sociedade através da participação nos conselhos e conferências de saúde (COHN, 1999).

De uma gestão extremamente centralizada, passa-se à descentralização como forma de garantir uma maior participação na formulação e implantação dos serviços e ações de saúde. O município ganha a atribuição fundamental de responsabilizar-se pela melhor política de saúde para a população local, e com a obrigatoriedade do funcionamento de conselhos de saúde nos três níveis de governo, o controle e a participação social vêm aumentando suas dimensões e aperfeiçoando seus métodos (BRASIL, 2000).

Além de seus pilares, é de fundamental importância entender os princípios que regem este complexo Sistema de Saúde: a universalidade não quer dizer apenas garantia imediata de acesso às ações e serviços de saúde, mas também o desafio de que esta oferta alcance a todos que dela necessitem, enfatizando as ações preventivas e reduzindo a ocorrência e o tratamento de agravos.

O princípio da equidade busca reduzir as disparidades sociais e regionais por meios das ações e dos serviços de saúde, na tentativa de alcançar um maior equilíbrio e igualdade de oportunidade no uso do Sistema.

A integralidade demonstra que a atenção à saúde deve levar em consideração as necessidades específicas de pessoas ou grupos, ainda que minoritários em relação ao total da população. Para a consecução deste princípio, uma das preocupações está na 
18 Introdução

humanização dos serviços prestados e das ações realizadas no âmbito do SUS (BRASIL,2000).

O Ministério da Saúde, através da Cartilha da Política Nacional de Humanização, apresenta a proposta da CLÍNICA AMPLIADA como um instrumento para que os trabalhadores e gestores de saúde possam enxergar e atuar na clínica para além dos pedaços fragmentados sem deixar de reconhecer o potencial de seus saberes. É o desafio de lidar com os usuários enquanto Sujeitos (BRASIL, 2007).

O conceito de CLÍNICA AMPLIADA deve ser entendido como uma das diretrizes impostas pelos princípios do SUS. A universalidade do acesso, a integralidade da rede de cuidado e a equidade das ofertas em saúde obrigam a modificação dos modelos de atenção e de gestão dos processos de trabalho em saúde (BRASIL, 2010a).

Segundo o Ministério da Saúde, a CLÍNICA AMPLIADA é definida como um:

\footnotetext{
"trabalho clínico que visa ao sujeito e à doença, à família e ao contexto, tendo como objetivo produzir saúde e aumentar a autonomia do sujeito, da família e da comunidade. Utiliza como meios de trabalho: a integração da equipe multiprofissional, a adscrição de clientela e a construção de vínculo, a elaboração de projeto terapêutico conforme a vulnerabilidade de cada caso, e a ampliação dos recursos de intervenção sobre o processo saúde-doença” (BRASIL, 2006b, p. $38)$.
}

Surge como uma estratégia de disseminação de tecnologias de humanização, se responsabilizando pelo usuário do serviço de saúde, ao mesmo tempo reconhecendo os limites dos conhecimentos dos profissionais.

Tal estratégia se preocupa com a fragmentação do cuidado à saúde, que vem desde o modelo biomédico e mostra suas consequências até os dias de hoje. Se todas as áreas de cuidado já sofrem deste mal, a saúde mental, área especializada e muitas vezes pouco incorporada e negligenciada dentro das rotinas da Atenção Básica à Saúde $(\mathrm{AB})$, recebe um peso ainda maior desta influência e se mostra como uma área pouco trabalhada no conjunto.

A fragmentação na área da saúde mental pode ser vista desde a equipe, que muitas vezes é dividida por competências e habilidades específicas e não consegue organizar-se de maneira horizontalizada, como também no cuidado ao paciente, que não consegue ser visto de forma integral.

É importante que estas equipes compartilhem saberes e práticas, rediscutindo cotidianamente as situações e determinando em conjunto as estratégias de intervenção. 


\subsection{Saúde Mental e Atenção Básica}

Saúde Mental é definida pela Organização Mundial de Saúde (OMS) como um estado de bem-estar no qual todo indivíduo realiza seu próprio potencial, consegue lidar com os estresses normais da vida, pode trabalhar produtivamente e é capaz de contribuir com sua comunidade. (OMS, 2008)

O campo da Saúde Mental tem como maior desafio capacitar as equipes para pensar (e agir em) saúde mental sem recorrer às velhas estruturas institucionais excludentes, construindo no dia-a-dia do trabalho novos dispositivos que possam efetivamente ajudar as pessoas a cuidar melhor da saúde e reorganizar suas vidas. Este trabalho deve ser feito em parceria com as famílias e a comunidade, ampliando a capacidade de escuta das equipes (GONÇALVES, 2000).

Antes do século XVII a doença mental era compreendida por sentidos místicos e espirituais e a loucura era vista com temor. Esta maneira de compreender o doente mental o levava a ser segregado e marginalizado na sociedade (GUANAES; JAPUR, 2005). Mecanismos de exclusão do louco já existiam, como os estabelecimentos destinados simplesmente a retirá-lo do convívio social.

O século XVIII marcou a apreensão do fenômeno da loucura como objeto do saber médico e sua caracterização como doença mental e, portanto, passível de cura.

Nesta época ocorreu a valorização do pensamento científico e o surgimento do hospital como um espaço terapêutico, entretanto, este acontecimento não deve ser visto sob uma ótica humanitária e positiva sobre o doente ou a doença, mas como uma anulação dos efeitos negativos do hospital (SILVEIRA; BRAGA,2005).

Este novo modelo hospitalar necessitava de instaurar medidas disciplinares para garantir seu funcionamento e assim surgiram os princípios de vigilância constante e delimitação do espaço físico. Com isso o doente mental estava cada vez mais distante das relações em sociedade e destituído de saber sobre si e sua doença.

Muitos anos se passaram até que este modelo de cuidado desumano e excludente pudesse ser transformado através de novas políticas de saúde mental, criadas no século $\mathrm{XX}$, buscando resgatar o direito à cidadania das pessoas portadoras de doenças mentais.

Antes de pensar sobre as políticas de saúde mental no SUS, é necessário resgatar a história da Reforma Psiquiátrica Brasileira, processo contemporâneo ao "movimento sanitário", que nos anos 70 lutava em favor da mudança dos modelos de atenção e gestão 
20 Introdução

nas práticas em saúde, equidade nas ofertas de serviços e defesa da saúde coletiva (BRASIL, 2005).

A Reforma Psiquiátrica está inscrita num contexto internacional de mudanças pela superação da violência asilar. Fundado ao final dos anos 70 , foi um processo político e social complexo, marcado por diferentes atores e incidindo em territórios diversos, compreendida como um conjunto de transformações de práticas, saberes, valores sociais e culturais (BRASIL,2005).

Foi no final da década de 70, com o Movimento dos Trabalhadores em Saúde Mental (MTSM), o início efetivo do movimento social pelos direitos dos pacientes psiquiátricos. Este movimento era formado por trabalhadores integrantes do movimento sanitário, associação de familiares, sindicalistas, membros de associações de profissionais e pessoas com histórico de internações psiquiátricas (BRASIL, 2005).

O movimento passa a protagonizar e construir a denúncia da violência dos manicômios, da mercantilização da loucura, da hegemonia de uma rede privada de assistência e a buscar a construção coletiva da crítica ao saber psiquiátrico e ao modelo hospitalocêntrico na assistência às pessoas com transtornos mentais (BRASIL, 2005).

Alguns acontecimentos merecem importância especial na luta pela reforma. No ano de 1987 ocorreu o surgimento do primeiro Centro de Atenção Psicossocial (CAPS) no Brasil, na cidade de São Paulo, uma estratégia de superação do modelo hospitalocêntrico de cuidado ao portador de transtorno mental, uma intervenção que demonstrou a possibilidade de construção de uma rede de cuidados efetivamente substitutiva ao hospital psiquiátrico (AMARANTE, 2003).

No ano de 1989 a Secretaria Municipal da Saúde de Santos (SP) iniciou um processo de intervenção em um hospital psiquiátrico, a Casa de Saúde Anchieta, local onde ocorriam maus tratos e mortes de pacientes. Neste período são implantados os Núcleos de Atenção Psicossocial (NAPS) em Santos, funcionando 24 horas e passando a ser um marco no processo de Reforma Psiquiátrica brasileira, demonstrando ser esta possível e exeqüível (BRASIL, 2005).

No processo da reforma manifestou-se uma tendência de oposição à desinstitucionalização, por entendê-la como mera desospitalização, ou radicalmente falando, como simples desassistência; um pensamento de que a desinstitucionalização significaria o abandono dos pacientes e não uma substituição do modelo de assistência e cuidado (AMARANTE, 1996). 
Essa visão contra o movimento de desinstitucionalização ganhou maior significado após o surgimento do projeto de Lei $\mathrm{n}^{\circ}$ 3.657/89, de autoria de Paulo Delgado, que propõe a progressiva extinção dos hospitais psiquiátricos e sua substituição por outras modalidades de assistência (TENÓRIO, 2002).

O projeto de lei, além de despertar setores contrários, resistentes a idéias que representassem a ampliação dos direitos e igualdade e aos que tinham interesses específicos na organização institucional da psiquiatria, também significou um marco político importante por possibilitar a ampliação do debate público sobre a loucura, a doença mental, a psiquiatria e suas instituições (AMARANTE, 1996).

É a influência iniciada ainda na década de 70, vinda de Franco Basaglia, psiquiatra italiano e precursor da reforma psiquiátrica de seu país, que ganha força neste momento e a partir daí o movimento brasileiro abandona sua especificidade de 'trabalhadores em saúde mental' para buscar tornar-se um movimento 'social' pela reforma psiquiátrica, com a estratégia de 'por uma sociedade sem manicômios' na tentativa de comprometer a sociedade no domínio do processo de desinstitucionalização.

Segundo Amarante (1996) as contribuições de Basaglia ofereceram à psiquiatria uma ruptura prático-teórica que pode servir de substrato para o surgimento de novas histórias e questões epistemológicas para a reforma psiquiátrica. O autor acrescenta que esta não é uma realidade estática, em equilíbrio, mas em construção e de invenção práticoteórica e que a cada momento se apresenta e se transforma.

Basaglia organiza um corpo teórico e um conjunto de estratégias para lidar com a psiquiatria, referenciado a partir de abordagens provenientes não apenas dos projetos de reforma psiquiátrica, mas fundamentalmente das chamadas "humanidades" e inicia uma trajetória original de desinstitucionalização na psiquiatria (AMARANTE, 1996).

No início da década de 90, movimentos sociais influenciados pelo projeto de lei de Paulo Delgado conseguem a aprovação das primeiras leis que determinam a substituição progressiva dos leitos psiquiátricos por uma rede integrada de atenção à saúde mental e é a partir daí que a política do Ministério da Saúde para a saúde mental começa a ganhar contornos mais definidos (BRASIL,2005).

Esta década foi marcada pelo compromisso firmado pelo Brasil na assinatura da Declaração de Caracas, documento que busca reformas na atenção à saúde mental nas Américas. Os signatários se comprometeram a promover a superação do modelo do hospital psiquiátrico e a luta contra todos os abusos e a exclusão de que são vítimas as pessoas com problemas de saúde mental (BRASIL, 2005). 
Somente no ano de 2001 que a Lei Paulo Delgado é sancionada no Brasil, com algumas modificações do Projeto de Lei original. A Lei Federal 10.216 redireciona a assistência em saúde mental, privilegiando o oferecimento de tratamentos de base comunitária, dispondo sobre a proteção e os direitos das pessoas com transtornos mentais, mas não institui mecanismos claros para a busca da extinção dos manicômios (BRASIL, 2005).

A promulgação desta lei impõe novo impulso e novo ritmo para o processo de Reforma Psiquiátrica no Brasil. O Ministério da Saúde cria linhas específicas para o financiamento de serviços abertos e substitutivos ao hospital psiquiátrico e uma nova maneira para fiscalizar e reduzir de maneira programada os leitos psiquiátricos no país (DELGADO et al., 2007).

A partir daí acontece uma expansão na rede de cuidados à saúde mental, alcançando regiões de grande tradição hospitalar, onde inexistia a prática da assistência comunitária em saúde mental. Neste período acontece a criação do programa "De Volta para Casa", um processo de desinstitucionalização de pessoas longamente internadas (BRASIL, 2005).

Este programa é um dos instrumentos mais efetivos para a reintegração social das pessoas com longo histórico de hospitalização, sendo uma estratégia de emancipação de pessoas com transtornos mentais. No entanto, para a sua efetivação, foi necessária a criação de dispositivos de atenção à saúde mental em uma rede integrada.

Neste sentido, apesar de estratégico, o CAPS não é o único tipo de serviço de atenção em saúde mental. A saúde mental, segundo o Ministério da Saúde, deve ser feita dentro de uma rede de cuidados, onde estão incluídos a atenção básica, as residências terapêuticas, os ambulatórios, os centros de convivência, entre outros (BRASIL, 2003).

Os municípios com menos de 20 mil habitantes não precisam ter CAPS, segundo a lógica de organização proposta pelo MS, e podem começar a estruturar sua rede de cuidados a partir da atenção básica (Brasil, 2003, p. 2)

Para a consolidação da Reforma Psiquiátrica é fundamental a construção de uma rede de cuidados em saúde mental com base na comunidade. A articulação desta rede composta de vários serviços é importante para a constituição de um conjunto sólido de referências que consigam acolher e dar suporte para a pessoa com sofrimento mental, em substituição à internação hospitalar prolongada. 
No SUS, o cuidado com a saúde está ordenado em níveis progressivos de atenção, envolvendo a atenção básica, a de média e a de alta complexidade. Esta organização visa ao melhor planejamento das ações e serviços de todo o sistema.

Nem sempre um município comporta a presença de todos os níveis de atenção à saúde instalados em seu território; no caso dos pequenos municípios, isso pode ser feito por meio de pactos regionais que garantam à população acesso a todos os níveis de complexidade do sistema. A prioridade para todos os municípios é a atenção básica, sempre devendo operar em condições plenas e com eficácia (BRASIL, 2006b).

Camargo-Borges e Mishima (2009) discutem que por ser o primeiro contato da população com o Sistema de Saúde, a Atenção Básica (AB) tem em sua organização o compromisso de ordenar todo o sistema de atenção na perspectiva da formação de uma rede integral e para isso deve estar sempre atenta às demandas do contexto local.

A rede de atenção à saúde mental do SUS se define como de base comunitária, que se articula com outras instituições, associações e cooperativas. É esta articulação em rede de diversos equipamentos do município, e não apenas equipamentos de saúde, que pode garantir a inclusão, promoção da autonomia e cidadania das pessoas com transtornos mentais (BRASIL, 2005).

Camargo-Borges, Mishima e McNamee (2008) discutem que o conceito de autonomia é trazido como apoiador das mudanças nas organizações e práticas em saúde. As novas propostas de intervenção em saúde levam em conta as necessidades das pessoas e valorizam a autonomia como forma de dar poder ao usuário e a comunidade.

As autoras discutem os espaços de intervenção coletiva na Atenção Primária à Saúde (APS) como potentes para a geração da autonomia, por propiciar maior interação entre profissional de saúde e usuário e se caracterizar como um ambiente de cuidado diferenciado.

A atenção em saúde mental também é marcada pelas propostas de cuidado integrado e intervenções mais humanas.

No Relatório Mundial de Saúde sobre a saúde mental, a OMS (2001) argumenta que há lugar para todos e que não se justifica excluir das comunidades as pessoas que têm doenças mentais ou perturbações cerebrais. O Relatório mostra como a ciência e a sensibilidade se combinam para derrubar as barreiras reais à prestação de cuidados e à cura em saúde mental, com uma compreensão sobre saúde mental e física como áreas integradas portando a complexidade da influência de uma sobre a outra. 
Este relatório proporciona uma nova maneira de compreender as perturbações mentais, analisando a prevenção, a disponibilidade e os obstáculos ao tratamento. Através do exame minucioso da prestação e do planejamento de serviços, a OMS (2001) cria um conjunto de 10 recomendações de longo alcance, onde cada país pode se adaptar de acordo com as suas necessidades e os seus recursos.

Uma das recomendações é proporcionar tratamento em cuidados primários, possibilitando ao maior número possível de pessoas acesso mais fácil e rápido aos serviços. Para que isso aconteça acrescenta que é preciso que o profissional de saúde em geral receba formação quanto às aptidões essenciais aos cuidados em saúde mental.

Outra recomendação é proporcionar cuidados na comunidade, obtendo-se melhor efeito sobre o resultado e a qualidade de vida das pessoas com perturbações mentais crônicas, do que o tratamento institucional. A mudança de doentes dos hospitais psiquiátricos para a comunidade pode ser mais eficaz em relação aos custos e quanto ao respeito aos direitos humanos.

A OMS (2001) recomenda a necessidade de pesquisas em saúde mental, a fim de melhorar a compreensão das perturbações mentais e desenvolver intervenções mais eficazes.

Uma intervenção criada na Argentina para trabalhar em saúde mental foi o Acompanhamento Terapêutico. Esse atendimento buscava abordar os pacientes em todos os aspectos de sua vida, criando um "meio-ambiente terapêutico" através da participação ativa dos acompanhantes terapêuticos (AT) nos diversos grupos (família, escola, trabalho) freqüentados pelo paciente (FIORATI, 2006).

No início o papel do AT consistia em um "estar junto" ao paciente em diferentes momentos de sua vida, coletando dados e não exercendo uma ação de intervenção sobre o processo de vida do paciente. Segundo Fiorati (2006) atualmente há uma nova tendência de introdução dessa prática nos serviços de saúde pública de atendimento à saúde mental.

Para Benevides (2007), pode-se dizer que no Brasil a Reforma Psiquiátrica é um vetor constituinte do AT, porque altera, produz, incentiva, abre portas do AT e é por ele constituída, num contexto onde o AT se (re) inventa. A autora relata se deparar em sua pesquisa sobre o acompanhante terapêutico na clínica, com uma questão metodológica. O AT apresenta-se não só como um modo de fazer a clínica, mas como uma função da clínica e a mesma é presente na prática de muitos profissionais da saúde. 
Fiorati (2006) discute o redimensionamento do campo de atuação do AT, deixando o enfoque direcionado apenas para a intervenção na área da psicopatologia e passando a constituir-se como um dispositivo em saúde pública.

O Agente Comunitário de Saúde (ACS) desempenha um papel que se aproxima ao papel e função do AT de acompanhar, seja através de visitas domiciliares, de orientações básicas aos usuários ou do vínculo formado com os pacientes pelo contato próximo e contínuo. Entretanto, a Estratégia de Saúde da Família, apesar dos enormes avanços e conquistas nos últimos anos, ainda enfrenta muitos desafios para se tornar hegemônica como uma proposta capaz de mudar o sistema de saúde e fazer frente ao modelo fragmentado existente (BRASIL, 2008).

A realidade das equipes de Atenção Básica demonstra que, cotidianamente, elas se deparam com a necessidade de enfrentar problemas de saúde mental. Pela proximidade com as famílias e a comunidade, as equipes de ESF se apresentam como um recurso estratégico para o enfrentamento de importantes problemas de saúde pública, como diversas formas de sofrimento psíquico (BRASIL, 2005).

Segundo Relatório do Ministério da Saúde (Brasil, 2005) existe um componente de sofrimento subjetivo associado a toda e qualquer doença, muitas vezes podendo atuar como barreira à adesão de práticas preventivas ou de vida mais saudáveis.

A inserção da saúde mental na ESF é emergente, já que tem sido crescente a demanda pela atenção aos transtornos psíquicos leves, mais prevalentes, manifestados sob diferentes formas, entre elas os quadros depressivos e os transtornos de ansiedade (SCÓZ; FENILI, 2003).

Pode-se dizer que todo problema de saúde é também, e sempre, um problema de saúde mental e toda saúde mental é também uma produção de saúde, o que torna importante e necessária a articulação da saúde mental com a Atenção Básica (BRASIL, 2003).

Pensando no fortalecimento da ESF e na melhoria da resolubilidade na Atenção Básica, o Ministério da Saúde propôs a criação dos NASF (Núcleo de Apoio à Saúde da Família). Esta proposta foi regulamentada em janeiro de 2008, pela portaria 154, e propõe que estes núcleos sejam constituídos por equipes compostas de profissionais de diferentes áreas do conhecimento, que atuarão em parceria com os profissionais das equipes de Saúde da Família, participando diretamente no apoio às equipes e na unidade a qual o NASF está cadastrado (BRASIL, 2009). 
$\mathrm{O}$ apoio matricial busca conhecer e interagir com as equipes da atenção básica em seu território, atendendo conjuntamente situações complexas e levantando dados relevantes sobre as demandas em Saúde Mental (RABELO; TAVARES, 2008).

Esta equipe deve funcionar com o objetivo de assegurar retaguarda à equipe e aos profissionais da atenção básica, oferecendo um suporte técnico pedagógico, objetivando ampliar as possibilidades de realizar-se a clínica ampliada e a integração dialógica entre distintas especialidades e profissões (CAMPOS; DOMITTI, 2007).

Rabelo e Tavares (2008) enfatizam a importância da reflexão e pesquisa sobre as novas práticas que se inserem no processo da reforma sanitária brasileira, que se justificam pelas deficiências das equipes de ESF quanto às atuações em Saúde Mental, muito influenciadas pelo modelo biomédico.

Segundo Figueiredo e Campos (2008), uma pesquisa do Ministério da Saúde de 2003 mostra que 56\% das equipes de ESF referem realizar 'alguma ação de Saúde Mental', mesmo que estas equipes nem sempre estejam capacitadas para lidar com esta demanda.

Para entender melhor estas ações dentro do contexto de atuação das equipes de saúde da família, é importante pensar sobre como este modelo de atenção surgiu e como seus princípios buscam reorganizar a Atenção Básica em Saúde.

\subsection{A Estratégia Saúde da Família}

O eixo norteador da política de atenção básica em saúde tem sido o compromisso com a intervenção nos processos de adoecimentos através de ações na comunidade (RABELO; TAVARES, 2008).

Nas décadas de 60 e 70, países como Canadá e México aderiram ao movimento de retorno do médico de família, numa tentativa de minimizar os efeitos da prática hospitalocêntrica e fragmentada que acompanhavam as especialidades médicas (VASCONCELOS, 1999).

No Brasil foi só na década de 90 que expandiu-se dentre os profissionais a concepção das práticas voltadas ao contexto familiar e à comunidade. A experiência de Cuba, com a implantação de programas de médico da família no país contribuíram para que reflexões sobre a família como foco do cuidado alcançassem nosso país.

Contribuições para a construção da Estratégia Saúde da Família (ESF) advieram do Programa de Agente Comunitário de Saúde (PACS) surgido no Ceará em 1987, que 
recebeu forte influência de vários programas aplicados em municípios brasileiros, como, por exemplo, a proposta de médico de família no município de Niterói (RJ), que se constituíam em espaços de diálogo e de encontro de vontades para superação das iniquidades (SOUSA, 2001).

O objetivo geral do programa era melhorar a capacidade da comunidade para cuidar da própria saúde e os específicos eram a redução do risco de morte puerperal e do recémnascido, o aumento da proporção de mães que amamentavam e a redução dos óbitos causados pela desidratação por diarréia (SILVA; DALMASO, 2002).

Com estes objetivos, desde o princípio os agentes comunitários de saúde (ACS) alteraram positivamente os indicadores locais, o que fez com que o Ministério da Saúde incentivasse a ampliação do programa para além das regiões Norte e Nordeste.

O agente comunitário exerce um papel fundamental no processo de vinculação das equipes com a comunidade, atuando na rede assistencial de forma inovadora (SEABRA, 2006).

Um dos requisitos para ser ACS é residir na comunidade onde atua, o que lhe permite conhecer melhor as pessoas e as suas realidades e assim não ser um estranho na sua área de atuação (WEBER, 2006).

Esta condição favorece o estreitamento de vínculos em conseqüência dos laços de confiança, respeito e compromisso que, normalmente, o ACS estabelece com a comunidade. Dessa forma, ele pode compreender melhor as condições e estilo de vida da população, bem como suas necessidades.

Silva e Dalmaso (2002) discutem que historicamente a idéia que apoia a inserção do agente comunitário de saúde envolve um conceito que aparece em diversas partes do mundo, representando a idéia essencial de elo entre a comunidade e o sistema de saúde.

Os autores destacam duas dimensões na proposta de atuação do ACS: uma mais técnica, relacionada aos atendimentos aos indivíduos e famílias e outra mais política, de organização da comunidade e transformação das condições de saúde.

\footnotetext{
"Assim, o agente aparece, nos diferentes programas oficiais, como um personagem fruto de uma tentativa de juntar as perspectivas da atenção primária e da saúde comunitária, buscando resolver questões, como o acesso aos serviços, no que lhe corresponde de racionalidade técnica, mas também integrando as dimensões de exclusão e cidadania, ou seja, o desafio de juntar o pólo técnico ao pólo político das propostas (Silva e Dalmaso, 2002, p.77)"
} 
Seabra (2006) afirma que o ACS deve informar os demais membros da equipe acerca da dinâmica social da comunidade, suas disponibilidades e necessidades e orientar as famílias para a utilização adequada dos serviços de saúde.

A experiência positiva com os ACS respaldou a criação do Programa Saúde da Família, no início da década de 90, que foi idealizado para agir como uma estratégia de reorientação do modelo assistencial, funcionando com a implantação de equipes multiprofissionais em Unidades Básicas de Saúde (BRASIL, 1997).

O modelo baseou-se em equipes multiprofissionais compostas, no mínimo, por um médico generalista ou de família, um enfermeiro, um a dois auxiliares de enfermagem e quatro a seis agentes comunitários de saúde. Cada equipe fica responsável pela atenção integral e contínua à saúde de cerca de 800 famílias localizadas em uma área geográfica delimitada (WEBER, 2006).

Para o Ministério da Saúde este programa representa um grande avanço em direção aos princípios estabelecidos na Constituição Federal: amplo acesso aos serviços de saúde, atenção integral, com qualidade, alta resolubilidade e para todos os brasileiros (BRASIL, 2002).

A partir da Portaria 648/2006 que define a Política Nacional da Atenção Básica. A Saúde da Família foi caracterizada pelo Ministério da Saúde como uma estratégia para o auxílio e expansão dos princípios do SUS, superando a denominação de programa, visto que o termo aponta para uma atividade com início, meio e fim. A Estratégia se caracteriza por buscar a reorganização da Atenção Básica, sem tempo determinado e previsto para o seu fim, além de poder valorizar as características e necessidades loco-regionais (BRASIL, 2006a).

É marcante a característica da ESF de ser uma possibilidade de conhecimento da estrutura e do sistema em que se organiza determinada comunidade, podendo prestar uma assistência universalizada, com descentralização de decisões e bases territoriais definidas para a atuação (PEREIRA et al., 2007).

A mudança do modelo assistencial do SUS por meio da ESF exige uma mudança no processo de trabalho da equipe de saúde que deixa de focar apenas na atenção às doenças e passa a ter seu foco dirigido à promoção e manutenção da saúde (MARQUI et al., 2010).

Segundo Weber (2006), a ESF reúne, concentra, representa e propaga o discurso paradigmático do SUS, que se materializa em ações e serviços de saúde com olhar na atenção primária. Para que viabilize seus atributos e princípios, as equipes devem fazer 
parte de uma rede articulada e integrada de cuidados, atuando com ações de promoção de saúde, prevenção, recuperação, reabilitação de doenças e a manutenção da saúde da comunidade (BRASIL, 1997).

Uma das características do processo de trabalho na $\mathrm{AB}$ e na ESF, comum a todos os membros da equipe, é a realização do acolhimento, entendido como escuta qualificada das necessidades dos usuários em todas as ações, buscando dar uma resposta resolutiva. Esta modalidade de atenção pode proporcionar atendimento humanizado e viabilizar o estabelecimento do vínculo (CONASS, 2007).

A consolidação desta estratégia, é um processo sustentado pela complementaridade da rede básica de serviços tradicional nos municípios e pela capacidade de produção de resultados positivos nos indicadores de saúde e da qualidade de vida da população assistida.

Segundo Bahia Pereira (2000), a atuação da equipe de saúde da família é extremamente vasta e plástica pelas diferentes demandas que surgem dentro da comunidade, pelo tipo de relação construída com as equipes e as articulações com organismos e instituições sociais. A autora acrescenta que a gestação de um modelo para produzir e pensar saúde se faz através do estabelecimento do diálogo, da troca de saberes e do trânsito intersubjetivo entre grupos de trabalhadores em saúde e a população.

O Ministério da Saúde aponta a Saúde Mental como uma das responsabilidades da ESF, já que muitas situações problemáticas neste campo são experimentadas pelas famílias atendidas por suas equipes (BRASIL, 2000).

Segundo Souza (2004), cabe à equipe do PSF desenvolver propostas de cuidados que incluam a Saúde Mental, partindo das situações observadas em seu cotidiano profissional e do conhecimento dos recursos disponíveis.

A obra organizada por Lancetti (2000), que reúne descrições e relatos de experiências em diferentes municípios do país, sobre a integração entre a saúde mental e a saúde da família aponta, ricamente, para a necessidade de aproximação destas duas áreas da saúde, com equipes que priorizam o trabalho na família e na comunidade e que buscam o exercício da cidadania de pessoas com transtorno mental.

Segundo este autor, essa estratégia de atenção requer mudanças na postura e na formação profissional, exigindo um trabalho psíquico e uma capacitação continuada. $\mathrm{O}$ vínculo formado com as famílias e a proposta de continuidade exigem lidar com o 
sofrimento humano, mas este é um processo para o qual os técnicos não estão preparados. (LANCETTI, 2000)

Souza (2004) discute sobre a importância do suporte técnico para os profissionais de saúde da família e considera que a realização de treinamentos e orientações propiciam maior resolubilidade do serviço às demandas de saúde mental e ainda melhoram o envolvimento dos usuários com transtorno mental e sua família.

Segundo Gonçalves (2000), a ESF requer das equipes um manejo instrumental das próprias ansiedades e o desenvolvimento de uma atitude afetiva e solidária diante da realidade da comunidade e de seu sofrimento. $\mathrm{O}$ autor ainda acrescenta que o programa de saúde mental precisa ser efetivamente "incluído" na estratégia de saúde da família para que possa operar satisfatoriamente. Ressalta, ainda, a necessidade de discutir continuamente sobre esta estratégia de trabalho e redefinir sua implementação, delimitando melhor as prioridades e limites das equipes.

Lancetti (2000) aponta ainda que, diante das necessidades apresentadas pelas equipes de saúde da família surgiu a necessidade de capacitação em saúde mental, que resultou na elaboração de programas de saúde mental que intensificassem a integralidade almejada pela estratégia saúde da família.

Por ser a Saúde da Família uma estratégia tão relevante para o fortalecimento da Atenção Básica de Saúde, é igualmente importante perceber como a equipe vê sua atuação e lida com a possível falta de preparo para assistir problemas relacionados à saúde mental.

A realidade das equipes de saúde da família do município onde foi realizado este estudo difere do modelo preconizado pelo Ministério da Saúde descrito nesta introdução, já que estas equipes não contam com uma equipe de apoio matricial, nem com capacitações e treinamentos na área de saúde mental.

Esta pesquisa se justifica pela inexistência de estudos no município sobre o tema, apesar de na literatura nacional este assunto ser encontrado em pesquisas que falam sobre o cuidado em saúde mental no contexto da Saúde da Família. Também se justifica pela possibilidade de contribuir para a melhora da qualidade da assistência à saúde. Este estudo poderá ser usado como um diagnóstico do serviço de saúde municipal e justificar futuras intervenções e mudanças que busquem a qualificação da assistência e do SUS.

O diagnóstico poderá sustentar a necessidade de capacitações, futuras contratações ou a continuidade do modelo de atenção já adotado. 


\section{OBJETIVO}

O objetivo deste estudo foi produzir sentidos com trabalhadores da Estratégia Saúde da Família, do Município de Serra Azul-SP, sobre seus recursos e necessidades para lidar com questões relacionadas à Saúde Mental. 


\section{O PERCURSO DO ESTUDO}

\subsection{O Referencial Metodológico: contribuições do movimento Construcionismo Social}

Neste estudo, o referencial metodológico qualitativo utilizado para a análise dos dados foi o construcionismo social. Este movimento surge abrindo possibilidades para novas reflexões no campo científico e inserindo-se no contexto dos estudos pós-modernos, dando ênfase à linguagem e à interação entre as pessoas na compreensão dos processos de construção de sentido (GUANAES 2006).

\footnotetext{
"Baseando-se, sobretudo, em concepções críticas às noções de objetividade, verdade e racionalidade, esta perspectiva rompe com preceitos gerais das teorias modernas, abrindo possibilidades para novas reflexões no campo científico" (GUANAES; JAPUR, 2008, p. 118).
}

O construcionismo social emerge problematizando a visão da ciência como uma descrição objetiva e acurada da realidade, na qual a linguagem é sustentadora da verdade.

Para os construcionistas, as ações do homem podem não ficar restritas pelas coisas tradicionalmente aceitas como verdadeiras, racionais e corretas; diante dele há um vasto espectro de possibilidades e um convite interminável para a inovação. Quando novas vozes são ouvidas, questões levantadas e alternativas refletidas, os limites de um novo mundo de significado são alcançados (GERGEN, 2009).

Neste movimento, os sentidos da realidade se constroem através de práticas discursivas, sendo a verdade produzida através de consensos estabelecidos socialmente por essas práticas.

Para o construcionismo a realidade social não se encontra pronta e acabada à espera de uma descoberta e nem algo que está internamente nas pessoas. O discurso construcionista aponta o entrelaçamento entre realidade e discurso, entendendo que a realidade social é construída conjuntamente na interação humana e dá à linguagem um papel fundamental, pois é nela que os sentidos do mundo vão sendo construídos (CAMARGO-BORGES, 2002).

Este movimento propõe que é por meio da participação em práticas discursivas que são produzidas conjuntamente descrições da realidade. A pesquisa construcionista não 
descreve o que as coisas são, mas o processo pelo qual elas são ativa e continuamente construídas entre as pessoas. $\mathrm{O}$ foco não são as estruturas relativamente estáveis do indivíduo ou da sociedade, mas sim os processos de construção do conhecimento e do mundo (RASERA; JAPUR, 2007).

O movimento construcionista social se preocupa, principalmente, em explicar o processo pelo qual as pessoas descrevem, explicam ou respondem ao mundo no qual vivem (GERGEN, 1985).

Neste sentido, preocupa-se com as explicações dos processos por meio dos quais as pessoas falam, descrevem os fatos e a si mesmas ou se posicionam no mundo em que vivem (SPINK; FREZZA, 2000).

A perspectiva multifacetada do construcionismo, tal como descreve Rasera e Japur (2007), busca se articular em torno de algumas questões centrais, e mesmo com a dificuldade de reunir um conjunto único de idéias, diversos autores entram em consenso frente a algumas descrições:

1. A linguagem não reflete um mundo independente, mas o constrói a todo o momento, através da utilização de determinadas descrições e explicações que se dão a partir das condições sócio-históricas concretas dos sistemas de significação.

2. As explicações sobre o mundo são resultado da coordenação da ação humana, construídos em relacionamentos, sendo o significado das palavras decorrente do seu uso social. As descrições sobre o mundo não são o resultado da observação objetiva da natureza, mas da construção de uma comunidade lingüística que através de processos sociais podem produzir significados locais duráveis no tempo.

3. As diferentes formas de descrever o mundo implicam diferentes formas de ação social, para o construcionismo a manutenção de certas tradições depende do processo contínuo de produção de sentido.

4. Considerando o conhecimento como sendo relativo e dependente de um conjunto de práticas e condições sócio-históricas, o construcionismo relativiza as formas usuais pelas quais descrevemos o mundo.

Quando as pessoas conversam, elas não estão simplesmente colocando idéias em palavras e nem refletindo a verdade de uma realidade delas independente: elas estão construindo sentidos e formas de vida (GUANAES; JAPUR, 2008). 
"Em nossas conversas, estamos sempre respondendo a outros (presentes ou não), endereçando a eles nossos enunciados, antecipando suas possíveis respostas e nos posicionando de determinados modos em uma situação discursiva (Guanaes, 2006, p. 35.)"

É sempre no momento interativo, no contexto relacional imediato, em uma zona dialógica e de incerteza, que o sentido se produz. Um enunciado sozinho não carrega nenhum sentido: é necessária a relação interativa e dialógica para que o sentido se dê (GUANAES 2006).

O foco de uma investigação construcionista social é o processo conversacional. Segundo Guanaes e Japur (2008), o interesse deste tipo de investigação reside no espaço relacional, não significando focalizar no que uma pessoa fala e a outra responde, mas no modo como seus enunciados se relacionam e o modo como elas constroem entre si, numa ação-conjunta, determinadas formas de vida e relação.

A pesquisa desenvolvida por epistemologias construcionistas, em abordagem qualitativa, transforma a subjetividade num recurso a mais. Este tipo de pesquisa permite a reflexão sobre como a pessoa do pesquisador incide sobre o delineamento da pesquisa e sobre suas interpretações, através de seus interesses e valores (SPINK; MENEGON, 2000).

Outra mudança trazida pelo movimento construcionista é a redefinição da lógica do rigor científico. O campo, neste tipo de pesquisa, é compreendido como prática social e a neutralidade do pesquisador sob o objeto pesquisado se torna impossível, já que está incluído no processo de produção de sentidos (SPINK; MENEGON, 2000).

\subsection{Contexto}

Serra Azul, Município onde foi realizado o presente estudo, está localizada no Nordeste do Estado de São Paulo, com uma área total de 282,85 Km2, possuindo uma população estimada de 11.259 habitantes (IBGE, 2011). O Município integra a região administrativa de Ribeirão Preto e está ligado à Direção Regional de Saúde (DRS) XIII, dentro da Região de Saúde do Aquífero Guarani.

A principal atividade econômica do Município é agrícola, voltada à cultura da cana-de-açúcar, o que faz com que sua população seja flutuante, aumentando no período da safra com a vinda de trabalhadores rurais de outras cidades e estados.

O grau de urbanização do município é de $91,43 \%$, com uma incidência de pobreza de $39,32 \%$, sendo que 47,38\% da população tem até 4 anos de estudo (DATASUS, 2010). 
A Rede Municipal de serviços de saúde é constituída de uma Unidade Mista de Saúde (UMS), que realiza atendimentos de emergência e clínicos, como clínica médica, pediatria, ginecologia, ortopedia, além de contar com outros profissionais como dentista, fisioterapeuta, psicólogo e fonoaudiólogo. A partir do começo do ano de 2010, o Município passou a contar com atendimentos quinzenais de psiquiatria. Alguns atendimentos de média e todos os de alta complexidade são realizados nos municípios de Ribeirão Preto, Serrana e Santa Rita do Passa Quatro.

O município tem em sua totalidade duas Unidades de Saúde da Família, uma chamada "Hermelinda Paim da Silva", inaugurada em 2002, que atualmente atende a 986 famílias e a Unidade “Dr Luiz Antônio de Araújo Dias", inaugurada em 2004, que atende a 826 famílias.

As duas equipes do Município não recebem qualquer tipo de acompanhamento de equipe de matriciamento tal como o preconizado pelo Ministério da Saúde. Também nunca receberam algum treinamento ou capacitação na área de saúde mental que pudessem colaborar com a adequação do atendimento aos pacientes com transtornos mentais.

\subsection{Constituição do "corpus"}

\subsubsection{Instrumento de Investigação}

Em função dos objetivos traçados neste trabalho, foram realizadas duas entrevistas utilizando-se o recurso do Grupo Focal. Esta técnica fornece informações de natureza qualitativa numa discussão focal que pode ser utilizada no entendimento de como se constroem as diferentes percepções e os diferentes sentidos sobre uma prática ou serviço (LLANES, 2005).

Segundo Iervolino e Pelicioni (2001), desenvolver uma pesquisa utilizando o grupo focal é desenvolver um processo que visa à compreensão das experiências do grupo participante.

O grupo focal consiste na interação baseada em tópicos oferecidos pelo pesquisador, que funciona como um facilitador do debate, que poderá adaptar-se aos objetivos e necessidades do grupo (GUI, 2003).

A tarefa essencial do moderador é manter o grupo em interação para obter dados sobre sua pesquisa, por um tempo de 60 a 90 minutos (KIND, 2004). Alguns autores ao 
36 O percurso do estudo

relatarem a técnica informam que o grupo deve ser composto por 8 a 12 elementos (ZIMMERMAN; MARTINS, 2008).

Algumas questões metodológicas são importantes na utilização do grupo focal como instrumento de pesquisa e uma delas é a influência da informação.

Essa influência se dá quando, por exemplo, um dos integrantes tem a habilidade de persuadir ou influir na decisão dos outros ou quando expõe uma informação muito extensa ao grupo, dificultando o posicionamento das outras pessoas na discussão (GONDIM, 2002).

Outra questão metodológica é a composição heterogênea do grupo, que pode facilitar a emergência de informações ou crenças não compartilhadas, fazendo com que os participantes adotem posições menos flexíveis do que em grupos homogêneos.

Como já mencionado, neste estudo entrevistou-se duas equipes de saúde da família compostas por diferentes categorias profissionais, tornando estes grupos heterogêneos. Esta composição do grupo pode gerar diferentes percepções sobre o assunto em foco, o que contribui para que o clima da entrevista seja desconfortável, prejudicando a troca de experiências e inibindo a participação de algumas pessoas. Por isso, durante a condução do grupo, o moderador deve exercer diferentes papéis: estimular os tímidos, desestimular os tipos dominadores (que não param de falar), solicitar esclarecimentos ou aprofundamento de pontos específicos, avançar para outros tópicos da discussão e finalizar o grupo (IERVOLINO e PELICIONI, 2001).

Kind (2004) relata que é consenso entre vários autores a importância do grupo focal como técnica que busca a produção de conhecimentos, sendo necessário que os moderadores estejam atentos ao processo grupal, além de capazes de avaliar as interações e se preocupar com a condução da discussão.

Embora recomendável a presença de um observador com o papel principal de analisar a rede de interações presentes durante o processo grupal, entendemos que para os objetivos deste trabalho, que não tem como foco o processo conversacional, não seria necessário este tipo de análise. 


\subsubsection{Procedimentos}

\subsubsection{Contatos Iniciais}

Os primeiros contatos com as equipes foram feitos nos dias em que a pesquisadora estava nas Unidades de Saúde da Família realizando atendimentos psicológicos como parte de sua rotina de serviço no município.

No mês de junho a pesquisadora comentou com as equipes que estava realizando uma pesquisa sobre a Estratégia Saúde da Família com uma interface com a Saúde Mental e que pretendia realizar entrevistas com as duas equipes de Saúde da Família do Município.

As equipes se mostraram interessadas em participar da pesquisa, falaram sobre a importância de valorizar a área da saúde mental no município e comentaram que os pacientes que tratam de doenças mentais também são atendidos pela saúde da família.

A pesquisadora, neste momento, comunicou que era justamente por terem de atender estes pacientes que ela gostaria de conversar com as equipes e ouvir delas como percebiam e de que forma lidavam com este contato.

A pesquisadora comentou que o Secretário de Saúde do Município já havia autorizado a realização do estudo e que seria feito um convite no próximo mês para uma conversa em grupo com toda a equipe.

Foi durante essas conversas que as duas equipes sugeriram que as entrevistas fossem realizadas em outro local, com maior privacidade e sem interrupções. Cada equipe mencionou quais seriam os melhores dias da semana para marcar a entrevista pensando na rotina de serviços das Unidades.

As equipes preferiram realizar o grupo no horário de trabalho devido ao fato de alguns profissionais morarem em outro município e terem outros locais de trabalho no período em que não estão na Unidade de Saúde da Família. Algumas agentes comunitárias estudavam fora do horário de trabalho, o que também dificultaria o encontro de toda a equipe em outro horário.

Duas semanas antes da data marcada, a pesquisadora foi até as Unidades e comunicou a cada equipe os dias escolhidos para cada entrevista e perguntou se todos os integrantes poderiam participar. Apenas uma agente comunitária estaria de licença após uma cirurgia e não participaria. 
38 O percurso do estudo

Neste último contato antes das entrevistas, a pesquisadora reforçou a informação de que a participação era voluntária, mas que seria importante a presença de toda a equipe para uma maior fertilidade do trabalho e da conversa em grupo.

\subsubsection{A Realização das Entrevistas}

As entrevistas foram realizadas no mês de agosto de 2010 e ao final da pesquisa todos os documentos e gravações foram armazenados e arquivados sob responsabilidade da pesquisadora.

Foi realizado o grupo focal de sessão única com as equipes em dias diferentes. Os dois grupos foram realizados no horário de trabalho das equipes, que se deslocaram até a sala de reuniões da Prefeitura Municipal, local proposto pela pesquisadora.

Nos respectivos dias de entrevista, a pesquisadora chegou ao local antes do horário combinado para arrumar a sala, que tinha uma mesa retangular grande, com cadeiras ao redor, possibilitando o contato visual de todos os participantes. Foi utilizado um gravador digital, que foi testado anteriormente.

A pesquisadora falou sobre seu projeto de pesquisa e seu objetivo de trabalho, de buscar compreender o que os participantes pensam sobre a saúde mental e como esta área está inserida no trabalho da equipe e o que o grupo, naquele momento, poderia conversar sobre Saúde Mental.

Neste momento, a pesquisadora informou que queria ouvir da equipe suas impressões e descrições do contato com os pacientes adoecidos mentalmente. Foi frisado que as respostas às perguntas não seriam consideradas certas ou erradas e que o que seria importante era a participação de todos, com suas opiniões e experiências sobre o que seria conversado.

Esclareceu-se a todos que suas participações seriam voluntária, mediante sua autorização através do termo de consentimento, que foi lido por todos antes da assinatura. Antes do início da entrevista, a pesquisadora solicitou o consentimento de todos para que a entrevista fosse gravada e todos os participantes concordaram.

A pesquisadora distribuiu crachás para que todos escrevessem seus nomes, o que facilitaria a identificação no momento da conversa e as anotações da orientadora da pesquisa, que foi observadora silente no primeiro grupo entrevistado. Na entrevista com a outra equipe não foi possível sua participação por compromissos profissionais. 
Na primeira entrevista, a orientadora da pesquisa se apresentou, dizendo seu nome e discorreu sobre seu papel no grupo, que ficaria mais em silêncio e anotando algumas percepções de conteúdos não verbais. Tais explicações foram importantes para que o grupo pudesse entender o silêncio da orientadora e o motivo de suas anotações.

$\mathrm{Na}$ segunda entrevista, a pesquisadora explicou que não seria possível a presença de um observador e que por isso a própria pesquisadora faria algumas anotações se necessário, sobre suas percepções e comunicações não verbais do grupo.

A pesquisadora utilizou um roteiro (Apêndice 1) com algumas questões importantes para a pesquisa e que gostaria que fossem discutidas pelo grupo, que seriam utilizadas sem uma ordem pré-definida. Iniciaram-se as discussões em ambos os grupos com o seguinte questionamento: O que vocês entendem sobre saúde mental?

$\mathrm{Na}$ entrevista com a Equipe Amarela a pesquisadora foi questionada se futuramente implantaria algum atendimento de Saúde Mental na equipe, sendo explicado que naquele momento o importante era compreender o que a equipe pensava sobre aqueles temas propostos.

A duração dos dois grupos foi de aproximadamente uma hora e vinte minutos, e ao término de ambos a pesquisadora agradeceu a participação e colaboração das duas equipes e se colocou à disposição para qualquer dúvida que pudesse surgir posteriormente.

\subsubsection{Os Aspectos Éticos}

Após autorização dos órgãos competentes e apreciação favorável do projeto pelo Comitê de Ética responsável (Anexo A), todos os profissionais das duas equipes de Saúde da Família foram informados sobre o estudo e convidados a participar do mesmo. A aceitação foi registrada pela assinatura do Termo de Consentimento Livre e Esclarecido (Apêndice 2).

Por entender que os resultados e conclusões desta pesquisa poderão ser úteis para as equipes entrevistadas, abrindo possibilidade de acrescentar ou modificar seus processos de trabalho, a pesquisadora planejou conversar com as equipes após a conclusão deste estudo, dando retorno sobre a pesquisa e os resultados obtidos, para que os mesmos possam contribuir de alguma forma com o trabalho desenvolvido por estas equipes, sujeitos desta pesquisa. 


\section{ENTREVISTAS REALIZADAS}

\subsection{Os Participantes}

Participaram deste estudo os profissionais das duas unidades de saúde da família do Município de Serra Azul, que atuavam na equipe há mais de seis meses e que concordaram em participar do mesmo. Apenas uma agente comunitária de saúde não pôde participar da entrevista por estar de licença após uma cirurgia.

A intenção de estabelecer como critério de inclusão um tempo mínimo de trabalho na equipe foi de que os participantes tivessem certa vivência na condição de profissional de Saúde da Família e que fossem conhecedores do processo de trabalho da equipe a que pertenciam.

Para a identificação das Unidades de Saúde foram usadas cores para preservar a identidade das equipes, além de utilizar nomes fictícios.

\begin{tabular}{|c|c|}
\hline Equipe Amarela & Equipe Verde \\
\hline Ana & Antônio \\
\hline ACS & Médico \\
\hline Joana & Camila \\
\hline Enfermeira & $\mathrm{ACS}$ \\
\hline João & Fátima \\
\hline Médico & Recepcionista \\
\hline Lia & Inês \\
\hline ACS & Aux. de Enfermagem \\
\hline Marina & Karina \\
\hline Aux. de Enfermagem & ACS \\
\hline Marta & Kátia \\
\hline ACS & ACS \\
\hline Tatiana & Melina \\
\hline ACS & Aux. de Enfermagem \\
\hline Vanessa & Paula \\
\hline $\mathrm{ACS}$ & ACS \\
\hline $\begin{array}{c}\text { Zulmira } \\
\text { Recepcionista }\end{array}$ & \\
\hline
\end{tabular}




\subsubsection{A Equipe Amarela}

Ana: 26 anos, agente comunitária de saúde que está na equipe há seis anos. Ela participou bastante da entrevista apesar de inicialmente ter dito que tinha vergonha. Foi responsável pelos momentos de descontração e falou sobre seu medo de adoecer: "ai quando eu vejo o paciente doente mental, eu morro de medo de ter doença mental, de ficar louca."

Joana: 31 anos, enfermeira e coordenadora da equipe, está na Unidade há oito anos sendo responsável pela equipe. Ela começou sua participação dizendo que deixaria o restante do grupo falar. Falou sobre sua visão de saúde mental como um equilíbrio de vários fatores como a alimentação, moradia e lazer. Sempre que o grupo ficava em silêncio ela lembrava que o que importava era a opinião de todos, reforçando a fala da pesquisadora: "Não existe certo e errado."

João: 37 anos, médico que está na equipe há dois anos. No início da conversa, depois do silêncio da equipe, ele iniciou falando sobre o que entende por saúde mental. Participou bastante da conversa, sempre falando sobre sua experiência como médico de família. Ao final da entrevista relatou vários casos de pacientes dependentes dos medicamentos como benzodiazepínicos e sua tentativa de retirada destes: "Então o pessoal(pacientes) tem uso abusivo de medicação, isso que eu tava lembrando agora."

Lia: 48 anos, agente comunitária de saúde que está na equipe há nove anos. Ela iniciou sua participação falando sobre a alta incidência de alcoolismo na cidade e colocou este problema como consequência da falta de emprego e lazer na cidade. Relatou sua experiência de acompanhar alguns pacientes psiquiátricos nas consultas em Ambulatórios de Saúde Mental: "Churrasco e bebida. Então eles não tem nada, isso acarreta tudo no que, lá na frente, que vai trazer problema psicótico, um monte de coisa..."

Marina: 28 anos, auxiliar de enfermagem que está na equipe há três anos. Ela foi a participante que menos se expressou verbalmente durante a conversa. Iniciou sua participação verbal quase no fim da entrevista dizendo que só de olhar já consegue identificar um paciente da área da Saúde Mental: "Ah dá pra perceber né, na hora você já percebe." 
Marta: 41 anos, agente comunitária de saúde que está na equipe há nove anos. Ela apenas se expressou verbalmente quando uma das participantes relatou uma visita feita em conjunto a um paciente psiquiátrico e pediu que ela relatasse o ocorrido. A partir deste momento ela participou poucas vezes da discussão e falou sobre sua experiência de acompanhar este paciente: "Mas a gente conseguiu uma grande coisa lá... Porque hoje a família dá remédio, leva ela na Saúde Mental...antes não levava..."

Tatiana: 34 anos, agente comunitária de saúde que está na equipe há dois anos. Iniciou falando que vê os problemas de saúde mental como falta de carinho e amor nas relações. Em outro momento relatou que não tem medo de lidar com os pacientes psiquiátricos e que tem vontade de ajudá-los: "Então eu acho assim, não sei, eu sinto vontade de ver aquela pessoa bem, sabe, de poder ajudar, fazer alguma coisa."

Vanessa: 33 anos, agente comunitária de saúde que está na equipe há nove anos. Falou sobre sua visão de que os fatores sociais estão ligados ao adoecimento mental. Ela falou também sobre o grupo que participa junto às outras agentes e uma fisioterapeuta no atendimento a mulheres em depressão: "E isso a gente já faz no Círculo do Amor, o grupo que a gente tem com a fisioterapeuta que trata um pouco isso né... Depressão, o físico...e a mente, com Yoga né..."

Zulmira: 32 anos, recepcionista que está na equipe há cinco anos. Logo no início do grupo, com o silêncio da equipe ela convidou o médico a iniciar a conversa. Ela participou bastante da discussão, sempre contando seu contato com os pacientes de forma engraçada: "O problema ta o seguinte, que um caso depende do outro. E fica tudo assim de mãos atadas, a gente não tem o que fazer".

\subsubsection{A Equipe Verde}

Antônio: 34 anos, médico que está na equipe há dois anos. Ele iniciou a conversa e a conduziu. Começou falando sobre o conceito de saúde mental, sempre lembrando que era apenas sua percepção. Foi a pessoa que mais falou, às vezes dificultando a participação de outras pessoas: "Na minha percepção saúde mental... eu não to falando conceito de livro, é o que eu acho... é o bem estar da pessoa, ou o objetivo disso, de buscar o bem estar mental, psíquico..." 
Camila: 23 anos, agente comunitária de saúde que está na equipe há três anos. Teve pouca participação verbal na discussão. Falou sobre um episódio em que foi conversando com o paciente para tentar acalmá-lo e que sente dó dos pacientes com problemas na saúde mental: “...todo mundo arregalou o olho assim, ficou com medo, eu falei assim 'ah, vou conversar com ela'."

Fátima: 32 anos, recepcionista que está na equipe há dois anos. No início do grupo pareceu estar com pressa para acabar logo e assim que alguém respondeu a uma pergunta ela pediu para já passar para a próxima. Ao final da entrevista deitou na mesa por algumas vezes e bocejou. Em alguns momentos riu das respostas e fez comentários com as pessoas ao lado: "Passa pra próxima..." e "O Doutor já falou tudo..."

Inês: 36 anos, auxiliar de enfermagem que está na equipe há três anos. No começo da entrevista não se manifestou e apenas falou quando a pesquisadora perguntou se as pessoas que não tinham falado concordavam. Falou sobre as pessoas que procuram a cura e o tratamento na religião: "Aproveitam a situação, ao invés de você gastar dinheiro com a medicação, você passa esse dinheiro pra igreja, né?"

Karina: 24 anos, agente comunitária de saúde que está na equipe há cinco anos. Participou bastante da conversa, falou sobre sua concepção de saúde mental e disse que falta preparo para a equipe dar acolhimento aos pacientes: "Eu acho que teria que ter realmente uma preparação pra dar acolhimento."

Kátia: 24 anos, agente comunitária de saúde que está na equipe há cinco anos. Participou poucas vezes da conversa, começando pela sua história de vida, com uma irmã adolescente que faz tratamento psiquiátrico e falou sobre a dificuldade de convivência com ela: " $E$ conviver com esse tipo de pessoa é difícil, eu falo por experiência própria, eu tenho minha irmã em casa, ela faz tratamento, tem depressão com 18 anos, toma um monte de remédio e é difícil demais, é muito difícil, porque cada dia é uma reclamação, cada dia ela tá sentindo uma coisa, deixa a gente louco lá em casa."

Melina: 26 anos, auxiliar de enfermagem que está na equipe há dois anos. Participou pouco da conversa e falou que a falta de estrutura da Unidade de Saúde prejudica o atendimento e acolhimento dos pacientes: “...as vezes a gente tá conversando com paciente e tem outro 
na porta escutando tudo que você tá falando, nem você nem o paciente fica a vontade pra tá discutindo alguma coisa."

Paula: 30 anos, agente comunitária de saúde que está na equipe há cinco anos. Foi a que menos participou verbalmente no grupo. Falou sobre os pacientes que buscam a cura apenas com medicação, negando sua doença: "Acha que tomando um remedinho vai lá e dorme, acabou..." e "Você acorda e os problemas tá tudo lá!"

\subsubsection{A participação da pesquisadora e da orientadora no grupo}

Mariana: 26 anos, psicóloga e pesquisadora deste trabalho. Já era conhecida das duas equipes por trabalhar no Município e realizar atendimentos nas duas Unidades de Saúde da Família. Sua participação foi ativa no grupo, com o papel de moderadora, facilitando a discussão, observando a interação grupal e procurando manter o foco no tema proposto no início do grupo. Durante as duas entrevistas procurou se utilizar da escuta e intervir na discussão apenas para facilitar a conversa ou esclarecer as perguntas que disparava para o grupo.

Maria do Carmo: assistente social, docente e orientadora deste trabalho. Participou como observadora da entrevista com a Equipe Amarela. Antes de iniciar o grupo focal, se apresentou, agradeceu a presença e a colaboração de todos com a pesquisa. Não participou verbalmente no grupo, fez anotações sobre a disposição das pessoas na mesa, comunicações não verbais e interação durante a entrevista.

\subsection{As conversas grupais}

Além do material gravado em áudio, as anotações e observações percebidas pela pesquisadora foram importantes para a análise dos dados.

Nos próximos dois tópicos serão apresentadas algumas descrições sobre o contexto de produção das conversas e percepções da entrevistadora sobre cada grupo separadamente. 


\subsubsection{Equipe Amarela}

O encontro com esta equipe ocorreu pela manhã. Os participantes chegaram juntos e com vinte minutos de atraso.

Após as explicações e orientações da entrevistadora todos os participantes leram o Termo de Consentimento entregue e assinaram.

Todos pareciam bem entusiasmados em participar da entrevista. Não houve conversas paralelas durante as falas, nem interrupções de terceiros.

A pesquisadora percebeu que no início das falas o grupo ainda estava um pouco hesitante, processo comum a todo início de grupo. Logo depois dos primeiros diálogos o grupo interagiu bem, todos se mostraram muito interessados em escutar quando alguém estava falando.

Com a técnica da coloração das falas dos participantes foi possível perceber que houve uma boa interação entre os participantes e que apenas duas pessoas tiveram pouca participação verbal, mas se mostraram atentas às falas e algumas vezes concordando com o que estava sendo dito com gestos e expressões.

Ao final do encontro o grupo se mostrou interessado em continuar a discussão em outros momentos e disse à pesquisadora que este tipo de encontro deveria ocorrer quinzenalmente.

Mesmo depois que o gravador foi desligado o grupo continuou conversando, falando que aquele tipo de discussão era importante para a equipe e que não tinham com quem conversar sobre aqueles assuntos.

\subsubsection{Equipe Verde}

$\mathrm{O}$ encontro com esta equipe foi marcado em outro dia no período da tarde. Todos chegaram juntos, com dez minutos de atraso.

A equipe parecia um pouco agitada, demorando para escolher os lugares que iriam ocupar na mesa e a pesquisadora esperou um pouco o silêncio do grupo até poder dar as explicações e orientações sobre a entrevista. 
Após entregar o Termo de Consentimento, alguns participantes leram e outros apenas assinaram. A pesquisadora leu o Termo em voz alta e falou da importância de todos concordarem com a gravação e participação no estudo.

A pesquisadora percebeu que esta equipe também estava hesitante no início, após a primeira pergunta houve um pouco de silêncio e logo após três participantes se manifestaram verbalmente. Neste momento, houve um silêncio de quase um minuto e um dos participantes pediu que passasse para a próxima pergunta.

A pesquisadora neste momento falou sobre a importância da participação do grupo, da troca de idéias e da interação de todos. A mesma participante neste momento disse que o médico já havia dito tudo.

O grupo se mostrou resistente em participar ativamente da conversa, sendo preciso vários convites da pesquisadora para que o grupo se colocasse, sem medo de julgamentos e ressaltando que ela estava interessada na opinião e experiência deles.

Ainda no início da entrevista, com menos de trinta minutos, alguns participantes começaram a conversar paralelamente atrapalhando a entrevista, algumas vezes dando risadas e falando baixo.

Em três momentos o celular de um dos participantes tocou, mas não foi atendido.

Através da técnica de coloração das falas foi possível confirmar algo que já havia sido notado pela pesquisadora: um dos entrevistados teve uma maior participação verbal na entrevista. Algumas vezes, este participante interrompeu a fala de outras pessoas para se colocar e talvez este domínio da entrevista tenha tornado-a mais cansativa.

Ao final da entrevista algumas pessoas estavam bocejando e uma delas chegou a se deitar na mesa.

Estas percepções da pesquisadora a fizeram repensar a construção do contrato grupal, que pode não ter colaborado com o sucesso da entrevista. O grupo teve dificuldades de produzir uma conversa com negociação de sentidos e de ação conjunta. 


\section{A ANÁLISE DAS ENTREVISTAS}

Segundo Spink e Lima (2000), também o processo de interpretação se caracteriza por ser um momento de produção de sentidos, sendo a interpretação um elemento intrínseco do processo de pesquisa. Os autores discutem que não há momentos distintos entre o levantamento de informações e a interpretação e que durante todo o percurso da pesquisa o pesquisador está imerso no processo de interpretação.

A seguir será descrito o procedimento seguido pela pesquisadora no momento de análise.

\subsection{Transcrição da entrevista e edição do material}

O início do processo de análise deste trabalho se deu com a transcrição integral e literal das falas, bem como a edição das duas sessões de grupo focal realizadas pela pesquisadora e pela orientadora do estudo, que participou de uma das sessões. As transcrições das duas sessões foram realizadas pela pesquisadora utilizando um editor de texto tipo WORD for Windows, o que gerou dois textos com quinze páginas cada.

Segundo Guanaes (2006), a partir das proposições construcionistas, a transcrição das sessões do grupo pode ser descrita como o primeiro momento ativo de produção de sentidos, que envolve um diálogo ativo da pesquisadora com o material coletado.

Este foi um momento onde a pesquisadora pôde ter uma primeira impressão sobre as falas grupais e começar a pensar sobre o processo de construção de sentidos realizado pelos dois grupos.

A edição do material foi feita pelos mesmos recursos utilizados por Guanaes (2006), que foram o uso de cores e a enumeração sequencial das páginas e linhas. Tal como sugere a autora, a pesquisadora associou uma cor específica à fala de cada participante, de uma maneira que seus enunciados aparecessem sempre com a mesma cor ao longo das transcrições. Este recurso favoreceu a percepção das relações grupais como as interações mais comuns entre os participantes, duração temporal de seus enunciados e distribuição do tempo de fala entre os participantes. 


\subsection{A Análise}

Este momento foi de leitura exaustiva das sessões transcritas e imersão nos conteúdos. As entrevistas foram lidas e relidas por diversas vezes para que fosse alcançada uma familiaridade com o material produzido. Algumas expressões e frases foram destacadas para permitir uma maior aproximação com os relatos e oferecer visibilidade aos conteúdos relativos ao objetivo desse estudo.

Esta etapa se constituiu então, em um olhar atento para cada enunciado em busca de impressões da pesquisadora, imersa num processo de produção de sentidos com as entrevistas.

Em seguida, a pesquisadora buscou interlocutores (pesquisadores que possuem familiaridade com a metodologia adotada) para conversar sobre as entrevistas e o material produzido pelos dois grupos. Através dessas conversas, à pesquisadora foi possível eleger os temas relevantes a serem descritos na análise das entrevistas.

Buscou-se focalizar a atenção nos enunciados dos participantes relativos às suas necessidades para lidar com questões de saúde mental. Ao mesmo tempo, ao descreverem suas ações concretas no trato cotidiano com essas questões, os participantes referiam os recursos que dispunham, embora parecessem não reconhecê-los como tal.

Após refletir sobre estes sentidos construídos no diálogo com as entrevistas, a pesquisadora escolheu dois temas, quais sejam: o discurso da falta e os recursos não reconhecidos.

Nesta fase, foi ainda possível apreender que a entrevista com a Equipe Amarela apresentava uma maior diversidade de sentidos, produzidos por um diálogo mais aberto e envolvido entre os participantes, e, portanto, mais útil para dar visibilidade aos temas escolhidos pela pesquisadora durante a pré-análise.

Como o pressuposto da perspectiva metodológica adotada neste estudo é que em pesquisa não se trata de revelar uma realidade objetiva, mas possibilitar novas descrições e novos entendimentos sobre o que se estuda, optou-se pela escolha da entrevista com a equipe amarela para a fase da apresentação dos resultados.

A pesquisadora fez esta escolha por ter percebido que nesta entrevista as relações estabelecidas foram horizontais, sem fronteiras entre os participantes, o que fez com que as diferenças de formação, conhecimento, status social e gênero, mesmo existindo, não 
impedissem a relação de troca entre os participantes e possibilitando ações dialógicas e de proximidade.

Na perspectiva do construcionismo social, esta fase consiste em dar visibilidade aos sentidos produzidos pela pesquisadora, de forma a convidar seus leitores a ampliar reflexões sobre o tema estudado.

Trata-se de produzir uma descrição dos temas escolhidos, destacando trechos das entrevistas que permitiram, à pesquisadora, formulá-los. 


\section{RESULTADOS: Apresentação e Discussão}

\section{Sobre o discurso da falta e os recursos não reconhecidos}

Os dois temas serão apresentados em tópicos separados.

O primeiro traz um olhar para o discurso da falta: Ele engloba momentos onde os participantes, ao conversarem sobre adoecimento/saúde mental, vão construindo sentidos relacionados à falta de estrutura do município, à falta de recursos nos pacientes e em suas famílias e à falta de recursos na equipe.

O segundo tópico dá visibilidade aos recursos não reconhecidos pelos participantes, conforme o olhar da pesquisadora. Esse tema refere-se ao preparo e disponibilidade para o cuidado em saúde mental que não são significados pelos participantes da equipe como tal.

Os trechos da entrevista que serão apresentados para ilustrar as categorias produzidas pela pesquisadora não serão trazidos de forma sequencial. No início de cada trecho será apresentada a linha e página correspondente a entrevista transcrita, que foi anexada ao trabalho (ANEXO B).

\subsection{0 discurso da falta}

Este tema foi abordado através de três sub-temas sustentados pelo discurso da falta e percebidos pela pesquisadora no momento de pré-análise, os quais foram nomeados como: "Não tem o que fazer na cidade, o que eles vão fazer?", “Eles não querem se ajudar" $e$ "Eu vou surtar".

O primeiro sub-tema versou sobre o discurso da falta onde o Município foi o foco da conversa e os participantes apontaram falhas, carências e pobrezas nas estruturas e serviços onde trabalham.

O segundo sub-tema foi composto pelas falas e enunciados em que os participantes descrevem os pacientes e suas famílias como sujeitos em que falta capacidade de autoajuda e aceitação da doença. 
O último sub-tema contemplou os enunciados em que os participantes falam de suas próprias faltas, das dificuldades encontradas no atendimento aos pacientes com doenças mentais e dos sentimentos surgidos neste contato.

\subsection{1 "Não tem o que fazer na cidade, o que eles vão fazer?"}

Neste eixo de análise foram percebidos vários enunciados que falavam de carências existentes no Município e que favoreciam o adoecimento mental da população. A equipe construiu o sentido de que a ocupação, o trabalho, o lazer, a alimentação e os esportes são fatores de proteção ao adoecimento mental.

Este eixo começa a ser traçado no início da conversação, com a pergunta da pesquisadora sobre o que era saúde mental para os participantes. A conversa se inicia com a fala de João, que pontua alguns aspectos que influenciam e interferem na saúde mental das pessoas. Ele traz para a discussão a idéia de que a situação social dos moradores da cidade e o uso de álcool e drogas interferem na saúde mental deles. Joana continua apontando a saúde mental como somatório de diversos fatores, como a existência de lazer, alimentação, parte social na vida do indivíduo.

A conversa tomou a direção de uma troca de idéias sobre o adoecimento mental e o grupo a descreve como um problema social, fazendo uma conexão com o desemprego e a ociosidade. Este é o momento em que a pesquisadora identifica o início da construção de sentidos sobre a doença mental como falta, ausência de recursos materiais que levam ao adoecimento.

O grupo parece justificar o adoecimento através das faltas existentes no Município, que é descrito como pobre em serviços sociais, culturais e assistenciais.

Vanessa traz para o grupo o sentido de que a falta de moradia e as carências sociais promovem o adoecimento mental e que a frustração, com o fato de não ter o almejado, leva à depressão.

Aparece na conversa uma relação da doença mental com o uso de álcool e drogas, ligado à falta de opções de lazer e esporte às pessoas da cidade.

Os participantes descrevem uma população que ao não encontrar possibilidades de trabalho, lazer, capacitação e ocupação na cidade; se ocupa com o consumo de bebidas alcoólicas e drogas, e, assim, surge a idéia de que esse consumo se dá por não existirem 
52 Resultados: Apresentação e Discussão

espaços que recebam as pessoas que se encontram nesta condição, que não há estrutura adequada para acolher e cuidar delas fora dos serviços de saúde.

(pg. 86 linha 7 até pg. 86 linha 47 - equipe amarela)

JOÃO: Primeiro tem que saber o que é o conceito de saúde né, tentar passar isso para área mental. O que é saúde ? É o bem estar físico, social... dentre outras coisas. E a saúde mental seria isso, a pessoa que está em plena capacidade cognitiva, de não ter transtorno nenhum e várias coisas influenciam nisso. Desde a situação social... (...)Até outros fatores, a gente vê muito aqui o problema de droga, muito problema de etilismo e isso tudo interfere, problemas externos na saúde mental. As agentes comunitárias vêem isso todo dia, nas visitas...

JOANA: (...) saúde mental pra mim é o que? É ter lazer, é ter a parte social, é ter esporte...É...Esporte inclui lazer já né...hum...Alimentação...Envolve tudo, entendeu, o que eu penso é isso aí, você tem que estar toda equilibrada.

\section{VANESSA: Moradia...}

JOANA: Moradia, tem que ter lazer...Tem que ter educação, então tudo correndo bem o individuo está bem mentalmente. É isso que eu penso.

(silencio)

VANESSA: Hoje a maioria das pessoas que a gente vê que desenvolve um transtorno mental, geralmente você vai colher a história, lógico que tem fatores hereditários, mas muitas vezes é por problema social realmente, por falta de moradia, por desemprego, por ...é...que entra a depressão né (...)

(...)

LIA: Aqui na cidade eu acho que ta tendo muito problema mental principalmente por causa do alcoolismo que é muito grande na nossa cidade. Por que? Não tem o que fazer na cidade, o que eles vão fazer? Vai pra bar, bebe, bebe, bebe e vai pra casa. Aí briga...Então eu acho que o que falta mesmo é um trabalho junto com o pessoal que ta ai desempregado, precisa de trazer mais coisa pra cidade pra tirar esse pessoal da rua, né e tem muito adolescente bebendo muito também, por que? Não tem um esporte pra praticar, não tem um incentivo pra nada na cidade.

ANA: Cultura...

VANESSA: Não tem um lazer, a festa deles é churrasco...

LIA: Churrasco e bebida. Então eles não têm nada, isso acarreta tudo no que, lá na frente, que vai trazer problema psicótico, um monte de coisa... 
Em outro momento da entrevista, quando a equipe conversava sobre alguns trabalhos realizados que beneficiam a saúde mental dos pacientes, Joana volta ao foco de que o Município precisa se estruturar para oferecer cursos e opções de esporte e lazer e fala que a falta de oportunidades de emprego também leva ao adoecimento.

Aparece o sentido de que a falta de coisas específicas acarreta o adoecimento e essa falta, na fala destes participantes, poderia ser preenchida por ações dos Órgãos Municipais, através de mais opções de entretenimento, lazer e emprego.

(pg. 92 linha 297 até 305 - equipe amarela)

JOANA: E além do mais eu acredito assim, que não depende só da gente, entendeu, como já foi falado, eu acho que o município tem que estar se estruturando, porque não depende só de a gente vai lá e fala "É isso e isso e isso" Mas e aí, o que eles vão fazer... Tem problema social, não tem um esporte, não tem um lazer pra eles estarem indo.

LIA: Não tem um curso, não tem nada.

JOANA: Então é complicado isso. O município tinha que ta estruturando também, alguma parte, esportiva... Pra eles estarem participando...(silêncio) Não tem emprego... porque a gente vê que os que estão mais sofrendo mesmo é a falta de dinheiro mesmo...que tá levando eles a adoecerem.

Os pensamentos surgidos no grupo vão ao encontro da Política Nacional de Promoção da Saúde, em que o SUS aponta a promoção da saúde como uma estratégia para enfocar os aspectos que determinam o processo saúde-adoecimento no Brasil, como o desemprego, a fome, a habitação inadequada ou ausente, entre outros.

Na perspectiva ampliada de saúde difundida pelo Movimento da Reforma Sanitária, os modos como os sujeitos elegem opções de viver como desejáveis, organizam suas escolhas e criam novas possibilidades para satisfazer suas necessidades, desejos e interesses, pertencem à ordem coletiva, uma vez que seu processo de construção se dá no contexto da própria vida (BRASIL, 2010b).

Nessa mesma perspectiva, os participantes constroem um sentido de cuidado para além dos muros das Unidades de Saúde e do próprio Sistema de Saúde, que incide em sua condição de vida e favorece escolhas saudáveis por parte dos sujeitos e das coletividades.

É através deste pensamento que os integrantes da equipe responsabilizam o Município por oferecer tais condições à sua população e parecem associar essas ofertas e 
54 Resultados: Apresentação e Discussão

estruturas municipais ao cuidado em saúde, sendo o desafio da intersetorialidade e a garantia do direito à cidadania, que aparecem nos diálogos construídos.

A equipe se apropria da idéia de que outros setores também devem se responsabilizar pela garantia à saúde desta população e ela parece identificar que existem falhas e faltas que devem ser melhor articuladas no Município para que haja condições de garantir saúde a esses pacientes.

\subsection{2 "Eles não querem se ajudar"}

Dos enunciados sobre a doença os participantes passam aos enunciados sobre o doente, também ligado à falta de recursos. Surgem descrições de um doente como alguém a quem falta iniciativa/vontade para se tratar, que tem dificuldade de aceitar seus sintomas psicológicos e prefere o tratamento farmacológico.

O doente é descrito através da falta de recursos próprios ou da falta de estrutura familiar. Acrescentam o sentido do convívio com a doença mental como produtor de novos doentes dentro de uma família.

Quando o grupo falava do uso de drogas e consumo de álcool na cidade, Tatiana iniciou sua participação na conversa afirmando que a falta de estrutura familiar é que leva ao que estava sendo conversado pelo grupo e trouxe a relação do abuso de substâncias ao ambiente familiar.

João diz que, independentemente da causa, ele observa que o estresses de cuidar e conviver com alguém com transtorno mental "pega a família inteira" e que é comum ver mais de um doente na família.

Neste momento, o grupo falou do sofrimento familiar existente no convívio próximo à pessoa com transtornos mentais e de que este sofrimento pode gerar mais adoecimentos.

Surgiu, neste momento, o sentido de que a falta de preparo também dos familiares para lidar com a doença mental e seus sintomas fazem com que adoeçam mentalmente também, passando de cuidadores a doentes.

João concluiu sua fala, com a descrição de um doente que não quer se ajudar, que busca no medicamento sua cura e que tem dificuldade de reconhecer sua capacidade de auto-ajuda. 
(pg. 87 linha 61 até 94 - equipe amarela)

ZULMIRA: A pessoa desequilibrada né, procura álcool, procura droga, procura só... Eles não têm assim onde recorrer pra se livrar (...)

VANESSA: Eu acho...

ZULMIRA: (...) Hoje eles procuram fazer mais o que é errado do que é certo $(\ldots)$

TATIANA: Eu acho que tudo isso, resumindo, é falta né... Falta de coisas materiais, principalmente eu acho, pra mim, que é a estrutura familiar, ocasiona tudo isso entendeu? Já vem da família, já vem. Em relação aos jovens, cresce naquilo, pai, mãe, então eu acho que é isso que ocasiona tudo. Pra mim é.

JOÃO: Independente de ser a causa, o que a gente vê muito é que nunca tem um caso só numa família né. A gente tem família aí que mãe ta deprimida, pai ta deprimido... pai tem transtorno de ansiedade ou alguma coisa, o filho já está insatisfeito.

(...)

Então vira uma coisa...a tal da síndrome do stress do cuidador. É a mesma coisa de cuidar de alguém acamado. Então não fica uma pessoa só doente. Aquele transtorno fica...pega a família inteira e não é difícil a gente ver isso lá (...) vai crescendo nesse ambiente, e, o transtorno vai fazendo parte daquilo lá e você lida como uma coisa natural...

TATIANA: E hoje em dia tudo assim...é muita falta de amor, de carinho né, é muita...

JOÃO: E uma coisa que eu sinto muito, a gente sempre ta falando e não consegue passar pro pessoal é assim: "ai eu quero um remédio pra melhorar". (...) Então a pessoa quer melhorar mas assim, como eu vou explicar...Quer melhorar mas não quer que ela faça alguma coisa, quer que alguém faça isso pra ela.

VANESSA: Não colabora, né.

JOÃO: Talvez isso seja até um mecanismo de desespero, de achar, "olha, eu não tenho mais capacidade". E a gente vê isso em famílias inteiras, e não só...

A equipe conversou sobre o paciente em questão como não ativo, com dificuldade de compartilhamento do seu cuidado e tratamento. Foi neste contexto que o sentido do doente que parece se omitir e se destituir como pessoa capaz de atuar junto com a equipe foi sendo construído.

Parece faltar algo, também nos pacientes, que ajude a equipe no seu cuidado e no seu atendimento. 
56 Resultados: Apresentação e Discussão

Quando surgiu na conversa a idéia de cuidado a esses pacientes, a pesquisadora perguntou se o grupo achava que a saúde mental era uma área para ser tratada pela saúde da família e eles disseram "com certeza", "não os casos surtados", mas que os primeiros atendimentos aconteciam na Unidade.

As falas no grupo deixam transparecer que a equipe propõe ajuda e assistência aos pacientes e os encaminham ao serviço especializado, mas que essa postura de omissão do paciente dificulta seu tratamento.

A equipe descreveu um paciente "desinteressado em se ajudar", que não aceita o tratamento psiquiátrico e que associa o encaminhamento para esta especialidade à loucura.

A equipe parece lidar com pacientes que ainda têm uma visão reducionista sobre a doença mental e não conseguem enxergá-la como resultante de diversos fatores e que pode ser tratada de forma humana e visando ao seu próprio bem-estar.

A equipe passa a culpabilizar o paciente e o descreve como omisso e sem autonomia.

Esta estigmatização do paciente é fruto, segundo Camargo-Borges, Mishima e McNamee (2008), de um entendimento da autonomia sob a perspectiva individualista, que esta centrada no indivíduo e o responsabiliza unilateralmente pelos seus atos. Neste modo de olhar, todo comportamento do paciente será compreendido como decorrente de um julgamento moral individual, seja vangloriando-o ou culpabilizando-o.

As autoras discutem que a não adesão ao tratamento fica limitada à culpabilização do paciente e fatores como o processo de trabalho adotado, a relação estabelecida entre equipe-usuário, o vínculo com o profissional e o serviço e o contexto da intervenção não são analisados.

Apesar da equipe entrevistada acreditar que a Saúde Mental deva ser considerada na Saúde da Família, é importante pensar em como esta equipe consegue enxergar estes pacientes, e o porque para elas, eles são vistos como desinteressados e sem vontade de se tratar.

Camargo-Borges, Mishima e McNamee (2008) apresentam o conceito de Responsabilidade Relacional (RR) como recurso/ferramenta de intervenção e para reflexão acerca da autonomia.

A RR trata sobre o processo de se relacionar, enfatizando o papel da dialogia em tudo o que fazemos e em seu aspecto teórico trata a produção do conhecimento como dialógico e relacional. Qualquer conhecimento e ação passam necessariamente por um 
processo de construção interativa (CAMARGO-BORGES; MISHIMA; MCNAMEE, 2008).

Este conceito tem um aspecto interventivo por se constituir como um recurso para a promoção do diálogo transformativo. A proposta é que se invista na construção de intervenções mais sensíveis às relações, num processo de sensibilização para uma comunicação maia colaborativa, responsável e que gerem interações menos polarizadas e hierarquizadas.

Este conceito, sendo discutido com esta equipe, poderia transformar e construir novas formas de intervenção no cuidado aos pacientes descritos aqui como desinteressados e omissos.

(pg. 88 linha 100 até 135 - equipe amarela)

PESQUISADORA: Então, dentro disso eu queria saber de vocês acham que a Saúde Mental é uma área pra ser tratada pelo Programa de Saúde da Família.

\section{JOANA: Com certeza.}

LIA: Com certeza... Assim... não os casos surtados... (risos)

JOÃO: Mas o começo acaba caindo lá. O começo acaba caindo lá.

LIA: É desde o princípio. A gente faz as visitas, você vê lá que tá precisando você vai agendar uma consulta né, pra ele.

ANA: É mas o PSF já cuida desses casos, porque o primeiro atendimento é lá.(...) o que teria que ter em Serra Azul seria a Saúde Mental, pra ta todo mundo trabalhando junto com esses pacientes.

JOANA: O que a gente observa também é que a gente propõe ajuda pra eles mas é que eles não aceitam entendeu? Que nem agora a Mariana ta atendendo lá com a gente, a gente marca e vai encima e a gente vê que eles não aparecem então eu acho que eles querem que caia uma coisa direta pra eles melhorarem. Eles não querem se ajudar. É que nem o Dr falou, eles não querem eles melhorarem, querem que a gente...Tem que partir deles também, não cabe só ao profissional. Que a gente fala "olha tem que fazer isso isso e isso" mas na hora do vamos ver eles acabam não fazendo. E acaba não indo procurar também né.

JOÃO: Tem muitos que você fala "Olha então vamos começar com a Psicóloga e depois você volta...” Acabou aí.

ZULMIRA: Tem pessoas que as vezes o Dr encaminha pra psiquiatria e dali mesmo, saindo já fala "O médico ta achando que eu sou louco, eu não sou louco não" (risos). Eles não aceitam as vezes, não aceitam 
58 Resultados: Apresentação e Discussão

passar pelo psiquiatra. Já sai xingando ali mesmo. Desinteressado em se ajudar.

João trouxe, em outro momento da conversa seu incômodo com os pacientes da saúde mental, que ele descreveu como repetitivos e se disse sobrecarregado com a atenção e o cuidado que esse tipo de paciente demanda.

Ana acrescentou à conversa a idéia de que essa demanda "não tem fim" e explica seu pensamento pelo fato de não haver cura para essas doenças.

João fez um relato de sua experiência como médico e disse que muitos pacientes fazem uso abusivo de medicação para dormir e que não querem fazer terapia e descreveu alguns pacientes resistentes aos tratamentos psicológicos.

Ana trouxe o sentido do remédio como vício, que deixa os pacientes dependentes de seus efeitos e que buscam, neles, uma forma de descanso e sossego.

Esta percepção mostra que falta para eles o recurso de perceber o que são sintomas na doença mental e como trabalhar com esses sintomas. Este estado do paciente é entendido pela equipe como falta de iniciativa, como problema e não como algo que, segundo o discurso psiquiátrico, faz parte da doença e que eles têm que lidar.

(pg. 96 linha 501 até 541 - equipe amarela)

JOÃO: (...) é um paciente que acaba enchendo o saco da gente... É repetitivo, por isso que as vezes não dá certo, manda pro CAPS eles vão no primeiro atendimento e não dão seqüência.. então é um paciente que demanda muito cuidado, muita atenção e as vezes você esta sobrecarregado (...)

ANA: Parece que é uma coisa que não tem fim, não tem cura né...

JOÃO: Porque é crônico né, é uma coisa que vai ficar, você vai ter que dá atenção sempre, sempre... mais dia menos dia vai voltar, pelo menos pra conversar...fazer alguma coisa e aí o pessoal abandona.(...) E o que tem de paciente aqui que a gente esqueceu de falar que faz uso abusivo de medicação, principalmente benzodiasepínico na cidade é absurdo. (...) Então dormir é muito bom né, quem não gosta de dormir...E não é só o remédio, é o que a gente falou, se juntarem as duas coisas não vai melhorar... Então o pessoal tem uso abusivo de medicação, isso que eu tava lembrando agora.

(...)

JOÃO: Tem uns que tomam, que precisariam de uma terapia, com psicólogo e falam "Ai não, não preciso não, o remédio funciona, eu sei que funciona"

ANA: Nós fomos fazer visita né, um paciente da Marta, é tudo da área da Marta, a senhora ela é viciada no Diazepam, toma todo dia, briga com a gente quando o Diazepam dela acaba (...) só que ela colocava no suco, 
dava pro marido, pros filhos, pros netos para eles dormirem e dar sossego pra ela durante o dia

(...)

ANA: Ela fala que quer descansar deles...

$(\ldots)$

JOANA: A saúde mental dela é o Diazepam.

No fim da entrevista, Ana volta a falar sobre algumas impressões que tem dos pacientes que precisam de atendimento na área da saúde mental e os descrevem através de um discurso individualista, sem conseguir pensar em uma responsabilidade coletiva para as construções feitas por estes pacientes.

(pg. 98 linha 627 até 636- equipe amarela)

ANA: Mas eu tenho prestado atenção, tem pessoas que precisam na minha área, tem uma mesmo que precisa, a gente conversa, fala, mas parece que não quer se ajudar, num faz um esforço, uma pessoa prostrada, ta vendo que ta precisando, vamos fazer alguma coisa, ai fala que queria mas sabe quando parece que não tem coragem de sair da própria casa pra fazer alguma coisa pro bem estar...

\section{VANESSA: São acomodados...}

ANA: Não sei o que pode fazer, e elas querem remédio, quer dormir...e não quer se ajudar...

O discurso da falta apareceu aqui como a ausência de disponibilidade do paciente em se ajudar, como uma dificuldade de se apropriar de seus recursos e de só enxergar, no remédio, a cura de sua doença.

Para a pesquisadora seria importante esta equipe poder conversar sobre estes pacientes tentando entendê-los, escutando-os do lugar onde genuinamente eles estão, para, assim, poder ajudá-los, entendendo porque para eles é tão difícil aceitar a doença e conseguir se ajudar.

Podendo pensar em outras formas de produção do conhecimento, focado nas interações, seria possível à equipe, percebê-la como implicada e relacionalmente responsável pela adesão destes pacientes ao tratamento.

E é nesse contexto, de construção de sentidos de um doente desinteressado, sem vontade de se ajudar e que traz certa dificuldade à equipe, que a pesquisadora questionou, ao grupo, se se sentiam preparados para o atendimento a esses pacientes. 
60 Resultados: Apresentação e Discussão

\subsection{3 "Eu vou surtar"}

A falta de preparo para lidar com esses pacientes apareceu como uma questão coletiva, a equipe começou a trazer para a conversa medos, cansaços, esgotamento e sentimentos de dificuldade, surgindo a idéia de que a equipe não se sente preparada.

Zulmira falou neste momento sobre seu estado emocional após acompanhar alguns pacientes ao ambulatório de Saúde Mental e falou do cansaço gerado pelo cuidado e convívio com pessoas com transtornos mentais.

Ela desabafou falando sobre seu medo de adoecer, que não se sentia preparada para essa aproximação. Ana continuou também trazendo o medo do adoecimento e o sentido da doença mental como loucura.

(pg. 89 linha 164 até 175 - equipe amarela)

ZULMIRA: Ontem mesmo eu fui na saúde mental, eu tava até comentando com a Joana hoje, que eu hoje to mal pra caramba, sabe? (risos).

JOANA: É cansativo.

ZULMIRA: É cansativo, você acaba se cansando mentalmente. (...) E eu fui lá ontem e nossa, voltei mal pra caramba. Aconteceu várias coisas ali que nossa, eu pensei "Eu vou surtar" (risos). Eu acho que eu ainda não to preparada, acho que eu não to. Sinceramente.

ANA: Eu acho que eu sou meio hipocondríaca. Aconteceu alguma coisa eu penso, eu tenho medo de acontecer comigo sabe. (...) ai quando eu vejo o paciente doente mental, eu morro de medo de ter doença mental, de ficar louca (risos).

Apesar do medo e cansaço, a equipe mostrou que está em contato com estes pacientes, que os acompanha apesar do despreparo.

$\mathrm{Na}$ fala de Tatiana apareceu a vontade de ajudar estes pacientes e o relato de uma experiência pessoal onde ela pôde cuidar de um irmão adoecido.

Talvez esta percepção de Tatiana, de maior disposição, seja possível pelo convívio próximo e afetivo que teve com um portador de doença mental e, por isso, conseguiu construir sentidos diferentes do restante do grupo, que não dividiu o mesmo pensamento com ela.

Este foi um momento onde a Tatiana profissional conversou com a Tatiana que é irmã, que vivenciou a mesma dor daquelas pessoas de quem o grupo falou. Tatiana 
conseguiu falar do lugar onde se encontram os familiares e as pessoas que lidam muito de perto com a pessoa com transtornos mentais e, por isso, se diferenciou um pouco do restante do grupo, pelo preparo que o convívio e contato próximo lhe deram.

(pg. 89 linha 176 até 182 - equipe amarela)

\section{TATIANA: Eu já não}

ANA: Eu tenho medo de ficar, como é que eu vou fazer.

TATIANA: Eu já tenho vontade de ajudar. De poder fazer alguma coisa. Porque eu já passei por situação assim, de ajudar, meu irmão ficou com depressão muito forte, e eu ajudei muito ele assim, até ele ficar bom mesmo (...) eu sinto vontade de ver aquela pessoa bem sabe, de poder ajudar, fazer alguma coisa. Eu já não tenho medo igual a Ana fala assim.

Ela se tornou uma voz isolada e a conversa continuou sem que o grupo se apropriasse da experiência e dos pensamentos trazidos por ela. $\mathrm{O}$ grupo deixou transparecer a necessidade de falar sobre os seus próprios sentimentos e dificuldades no contato com esses pacientes.

Joana falou sobre a vontade de ajudar os pacientes, mas terminou dizendo que essa ajuda é complicada para a equipe.

Ana trouxe a concepção de doença mental como causa genética, falando sobre o medo de adoecer mentalmente por ter casos de doentes na sua família, aparece aqui a possibilidade de haver uma predisposição para o seu adoecimento mental.

Tsu \& Tofolo (1990) em pesquisa sobre as concepções etiológicas de pacientes psiquiátricos acerca da doença mental, constataram que as pessoas normais tendem a ver a doença mental como uma predisposição de nascença ou anormalidade congênita. Essa concepção envolve uma tentiva das pessoas de se defenderem de temores relativos à possibilidades de se tornarem doentes mentais.

(pg. 89 linha 183 até pg. 90 linha 207 - equipe amarela)

ANA: Eu tenho medo de ser futuramente, porque eu tenho parente que tem. Na minha família tem caso. (risos) Aí minha mãe fala que eu tenho um pezinho lá. Então, futuramente eu falo "Ai meu Deus se eu ficar doida”. Essa é a preocupação.

JOANA: Então, lá no PSF a gente atende esses casos, mas quando aparece muito, o que eu percebo é que chega no final do dia a gente ta esgotado. 
62 Resultados: Apresentação e Discussão

JOÃO: Todo mundo

JOANA: Estressado, então eu acho que é uma parte muito difícil pra ser trabalhado, e é o que a gente ta mais tendo, só que eu acho muito cansativo.

LIA: Tem que estar preparado pra isso.

$(\ldots)$

JOANA: É muito cansativo, estressante mas eles precisam de ajuda, mas é complicado pra gente.

Destacaram-se para a pesquisadora as dificuldades sentidas pelos participantes desta equipe que vão desde a falta de estrutura dos pacientes até a falta de estrutura dos serviços municipais, que aparecem como desestruturados e distantes da equipe do PSF. Os participantes falaram da falta de apoio e do fluxo contrário ao estabelecido pelo SUS que chegam a receber pacientes em surto.

Segundo o Ministério da Saúde, uma grande parte do sofrimento psíquico menos grave continua sendo objeto da Atenção Básica (AB), mas alerta que nem sempre a atenção básica apresenta condições para dar conta dessa importante tarefa. Reconhece que atender às pessoas com problemas de saúde mental é de fato uma tarefa muito complexa (BRASIL, 2003).

Talvez o apoio que a equipe mencionou na conversa seria uma melhor articulação da rede de cuidado, ainda que pequena, do Município. Eles relataram que, muitas vezes, do pronto atendimento do Município, alguns pacientes em surto, foram encaminhados para a saúde da família.

Receber esses pacientes com comportamentos alterados e psicóticos, além de não ser uma demanda para a Saúde da Família, causa um desconforto na equipe, que não foi capacitada e orientada para cuidar de pacientes em tal situação.

A enfermeira Joana fez um desabafo dizendo que a equipe faz o que é possível para assistir os pacientes que chegam a sua Unidade e, muitas vezes, assume uma função que não seria sua, como regular estes pacientes para o atendimento especializado.

(pg. 92 linha 333 até pg. 93 linha 383 - equipe amarela)

JOANA: Apoio... esse é o grande problema, porque, assim...nós estamos fazendo o que a gente tá conseguindo, o que dá, mas apoio e contato com ele (gestor) a gente não consegue, pra sentar e falar "vamos discutir hoje sobre isso isso e isso" 
ANA: O que eu vejo é que quem ajuda muito é a Joana, quando ela liga muito em Santa Rita, ela faz a regulação sabe...E as vezes lá embaixo, que teria que sair de lá não consegue, pede pra ela fazer...

JOANA: É a gente sofre muito com isso mesmo, porque os pacientes chegam surtados na Unidade e aí eles já pergunta de que área que é, a pessoa fala "Ai sou la do PSF 1" Aí taca lá pra gente, o paciente chega lá surtado, e o ambiente é pequeno.

TATIANA: Sem estrutura nenhuma...

JOANA: Sem estrutura e aí cabe a gente fazer a regulação pra não deixar o paciente ali...

ZULMIRA: O problema ta o seguinte, que um caso depende do outro. E fica tudo assim de mãos atadas, a gente não tem o que fazer. Eles também não faz nada, não tem ambulatório, não tem nada, fica assim ó. Fica um jogando pra cá, um jogando pra lá...

(..)

JOANA: Ai isso vai cansando e a gente que não vai agüentando mais. E já não tem um ambiente adequado, né, não tem sala pra enfermeira lá.

ZULMIRA: Na pré-consulta o pessoal ta ali em cima. Não tem nem como conversar direito também.

A entrevista veio sustentada pelo "discurso da falta", em que a equipe não conseguiu acessar e se apropriar dos recursos já existentes no seu processo de trabalho e a quantidade de ações já desempenhadas por ela.

A equipe falou de vários impedimentos que atrapalham o atendimento, faltas de capacitação, preparo, estrutura e pareceu não ter percebido aquilo que eles fazem apesar de todas estas dificuldades.

Tais dificuldades foram entendidas e reconhecidas pela pesquisadora, que acredita que muitas coisas podem ser melhoradas e revistas, tanto pela equipe quanto pelos gestores municipais da saúde e outros setores.

Mas além de mudanças e melhoras é importante, neste momento, o reconhecimento daquilo que já existe nesta equipe e que já apresenta resultados positivos no cuidado em Saúde Mental.

\subsection{Os recursos não reconhecidos}


64 Resultados: Apresentação e Discussão

A análise do material produzido pelo grupo permitiu à pesquisadora reconhecer muitos recursos da equipe no trabalho com a Saúde Mental. Este tema visa a trazer descrições produzidas pela equipe no contexto de atendimento às pessoas com doenças mentais, dando visibilidade aos recursos desses trabalhadores, que não pareceu serem legitimados e reconhecidos por eles.

No momento em que a pesquisadora convidou a equipe a falar sobre o que seria necessário para que eles se sentissem preparados para lidar com os pacientes da Saúde Mental, eles falaram sobre capacitação, tratamento, cursos, grupos.

Joana coloca a idéia de que seria necessário um atendimento em grupo para a equipe, que precisa “extravasar". Dessa forma traz o sentido de que esta equipe também precisa ser cuidada, porque possivelmente as ações que estão sendo desempenhadas por ela, no atendimento aos pacientes da saúde mental, adoecem a equipe, que precisa também de tratamento.

Neste momento, Lia pediu licença ao grupo para falar sobre uma experiência que teve ao acompanhar três pacientes que "estavam surtados" segundo sua fala, e foram atendidos em ambulatório de Saúde Mental em Ribeirão Preto.

Esta foi uma fala onde Lia descreveu um envolvimento e uma disponibilidade para estar junto a esses pacientes, revelando recursos com potência para tornar esta disponibilidade real.

(pg. 90 linha 209 até pg. 91 linha 254 - equipe amarela)

PESQUISADORA: E o que vocês acham que seria necessário para que vocês então se sentissem preparados?

LIA: Precisa de um curso, uma capacitação, alguma coisa.

ZULMRA: Uma capacitação, é. Uma preparação, pra entender.

JOANA: Acho que mensal, ou sei lá, tinha que ter algum grupo com a gente, com os profissionais... pra ta...né, fazer o tratamento em nós também, extravasar...Porque precisa...

LIA: (...) deixa eu te contar uma experiência (...) Tava eu e a Jack, nós fomos levar o Otacílio, a Helena, que é irmã do Otacílio e a D. Leila na saúde mental. Os três estavam surtados... Lá, era para internar D. Leila e eles não internam, tinha que sair daqui a regulação. E ela tava tão surtada que ela ficava assim "Lia, lia, lia... Pedro, Pedro, Pedro...Jack, Jack, Jack...." Ela brigou com todo mundo na Saúde Mental, a mulher queria colocar nós para fora (...) isso era 4 horas da tarde quando eles passaram pra pegar a gente lá. Nós saímos daqui 7 horas da manhã. Eu sei que no final das contas eu que fui pro Pronto Socorro, porque me deu uma crise 
de bronquite que eu quase morri lá...é complicado porque você pega a carga pra você deles. Deus me livre.

JOANA: Por esse exemplo que a Lia deu, a Saúde Mental também sendo saúde mental, colocar eles pra fora, eles também não tão preparados.

LIA: Preparados...

JOANA: O serviço não ta preparado.

LIA: O serviço social, lá de dentro, a mulher falou pra nós "Olha, se ninguém resolver eu vou colocar vocês pra fora" "Falei meu deus do céu, Jack do céu". Ai nós começamos a ligar sem parar aqui (na Unidade de Saúde) (...) então sabe é complicado porque na verdade eles não tinham com quem ir, e... A Helena brigando com a D. Leila, mas foi um "furdun"... já começou dentro da ambulância, a brigar, eu falei "Hoje vai ser feroz". Então, sabe...

ZULMIRA: Eu acho que o serviço social deixa a desejar, eles não se preocupam muito, pra resolver um problema demora muito também...Sabe, e a pessoa tem que humilhar muito também, a pessoa já tem um problema, ai chega lá tem que se humilhar, as vezes a pessoa fica pior ainda. (...) Eu to fazendo serviço social, eu tô tentando aposentar o Otacílio, nem tenho obrigação mas to fazendo por caridade, sabe, de ver a situação deles, tudo... Porque com um dinheirinho lá vai ficar tudo bem...não vai dar trabalho pra nós..

ANA: É até melhor pra gente.

ZULMIRA: Porque a Helena tendo dinheiro, o Otacílio tendo dinheiro eles ficam bem...Quando entra um dinheirinho pra eles, eles ficam bem... Talvez eu vou ficar pior (risos)...não sei...to tentando tipo assim... ajudar, vamo vê.

Ao fazer o relato, os recursos utilizados por esses profissionais não foram apropriados e reconhecidos por eles. Zulmira trouxe neste momento uma importante percepção que teve para conseguir ajudar uma família de dois pacientes com transtornos mentais que são acompanhados na ESF. Ela conseguiu identificar que uma aposentadoria, um recurso financeiro seria importante para uma melhor convivência dos dois, que não têm recursos para se manterem e, muitas vezes, isso os desestrutura.

Lia fez o reconhecimento de que aprendeu sobre Saúde Mental através de seu trabalho como agente comunitária de saúde, lidando no dia a dia com esses pacientes. Neste momento, ela construiu o sentido de que não foi preparada para saber como lidar com estes pacientes e que as coisas que consegue fazer são construções suas, aprendidas pela experiência e pela disponibilidade em oferecer ajuda. 
66 Resultados: Apresentação e Discussão

Logo após, surgiu na conversa a idéia de que a ESF deve trabalhar com a prevenção, com a tentativa de não adoecimento de sua clientela e que após o aparecimento da doença mental eles devem encaminhar o paciente ao atendimento especializado.

Apesar do discurso da necessidade de encaminhamento e do trabalho apenas com a prevenção, surgiu na conversa um trabalho já compartilhado pela equipe junto a fisioterapeuta, de ajuda às pacientes com depressão através de massagens, relaxamento e Yoga, com o objetivo de trabalhar o autoconhecimento e o controle das emoções.

Este grupo pode ser caracterizado como um trabalho em saúde mental na Atenção Básica, que atende pessoas com transtornos mentais leves e consegue evitar seu encaminhamento para níveis de atenção mais complexos.

(pg. 91 linha 260 até pg. 92 linha 296 - equipe amarela)

LIA: Eu tive alguma coisa de saúde mental, alguma aula foi quando eu fiz o curso técnico. O que a gente aprendeu foi no dia a dia também.

JOANA: É no dia a dia.

\section{LIA: Nas visitas...}

VANESSA: Mas como lidar com o problema não...

PESQUISADORA: Então vocês acham que pela experiência, do dia a dia, vocês aprenderam um pouco, é isso?

JOANA: Uhum...

LIA: Um pouco viu...

JOANA: Acho que até bastante viu...

\section{(...)}

JOANA: (...) a gente do PSF tem que trabalhar antes pra que eles não venham a ficar doente...

ANA: Com a prevenção né...

JOANA: Com a prevenção né e ai a partir do momento que ele já ta com o problema mental, já ta doente mental, aí ele seria encaminhado pra esse ambulatório. Porque nossa é muito difícil.

\section{(...)}

VANESSA: Porque o PSF, nós, não tem como você tratar, implantar ali a saúde mental ali, mas assim, como o Dr falou, a prevenção sim (...) teria que ter realmente esse ambulatório pra eles serem tratados lá e assim, a gente com parceria com eles, na fiscalização, nós agentes vendo se eles estão tomando a medicação, colaborando, mas não atuando diretamente, 
porque não tem como, nós não temos só saúde mental, nós temos outros grupos (...) por isso que tem que ter só o saúde mental e a gente com prevenção e ajuda. E isso a gente já faz no Círculo do Amor, o grupo que a gente tem com a fisioterapeuta que trata um pouco isso né... Depressão, o físico...e a mente, com Yoga né...

ANA: Massagens, relaxamento...

VANESSA: A pessoa aprendendo a se conhecer, até pra gente mesmo...

ANA: A lidar com as emoções no momento certo. Ela ta focalizando isso com a gente.

VANESSA: As emoções...e amor né...

Em outro momento, Zulmira trouxe para a conversa a capacidade da equipe de ouvir e conversar com os pacientes e que estes reconhecem a ajuda e se beneficiam dela. Joana fala do cansaço que essa disponibilidade traz para a equipe, que muitas vezes se sente esgotada e que essa escuta acontece em um local desapropriado.

A visita domiciliar apareceu como um instrumento de aproximação e favorecimento do vínculo da equipe com os pacientes, que sentem liberdade para expor seus problemas e pedir ajuda à equipe.

Ana relatou a experiência que ela e Marta vivenciaram com o acompanhamento que fizeram a uma paciente que precisava de medicação assistida e que não tinha ajuda da família. Ela relatou o acontecimento de um dia onde precisaram socorrer a paciente que estava sendo ameaçada pelo irmão, também doente, que estava "surtado". Neste momento, apareceu um dos sentidos construídos de cuidado a esses pacientes, como o de ser "salva vidas", de estar preparado e disponível para atender e cuidar deste doente.

(pg. 93 linha 376 até pg. 94 linha 427 - equipe amarela)

ZULMIRA: E outra, as vezes parece que a Joana que é a psicóloga lá. O pessoal chega lá e fala "Preciso falar com você" (...) Ai a Joana conversa, conversa e pessoa sai bem. No outro dia parece que é o retorno "Ai Joana eu to bem, vim conversar com você de novo".

JOANA: Ai isso vai cansando e a gente que não vai agüentando mais. E já não tem um ambiente adequado, né, não tem sala pra enfermeira lá.

LIA: Mas nós na visita (...) a partir do momento que você já conhece a pessoa eles tem a liberdade de chegar pra você e contar o problema deles, eles acham assim, eu vou contar e ela vai tentar resolver meu problema, então fica bem mais fácil quando você tem um vínculo. Ai agora, aqueles casos que são mais complicados, como na nossa área lá (...) O médico que tava de plantão olhou e falou que o paciente não tinha 
68 Resultados: Apresentação e Discussão

necessidade de ser internado... (...) Só que ela já me procurou... Outro dia ela chegou lá "Cadê a Lia, cadê a Lia, tem que internar o Fulano" "Ê Ê, eu não" Porque eu tenho medo entendeu, pelo que ele já fez...

\section{(...)}

ANA: A gente já até correu risco também com esse tipo de problema. Esquizofrênico né Joana? (...) A Marta levava remédio pra ela todo dia, porque ela morava num cômodo, no fundo, e a família inteira saia pra trabalhar, a irmã dava remédio pra ela só que ela jogava fora, ai ela foi surtando, ficando mal, acho que no último estágio de loucura. Aí precisou de fazer um acompanhamento, ai eu e a Marta ia lá na casa dela todo dia, misturava o remédio ou no leite, ou na água né Marta? (...) e ficava olhando ela tomar. Levava pão, café, pra ela poder tomar essa medicação. Aí um dia chegamos na casa dela pra fazer isso e o irmão dela também é esquizofrênico, estava surtado, tava lá com ela, com uma barra de ferro dizendo que ia matar ela e quebrando a casa inteira. Aí a gente não sabia se chamava a polícia ou se entrava pra salvar ela...

MARTA: Aí a gente entrou pra salvar ela...

ANA: Aí nós entramos lá correndo, pegamos ela, e saímos pra fora, chamamos a polícia e ele lá quebrando tudo, querendo bater em todo mundo...

MARTA: Destruiu tudo a casinha dela...Mas a gente conseguiu uma grande coisa lá... Porque hoje a família dá remédio, leva ela na Saúde Mental...antes não levava...

ANA: É...

$(\ldots)$

JOÃO: Vocês quase apanharam...

(risos)

ANA: Foi o dia da Liga da Justiça

MARTA: Mas você vê, os pacientes tem uma confiança muito grande.

Mas essa disponibilidade e essa postura também refletem na saúde dessas pessoas, que trouxeram para a conversa um discurso de cuidado, que gera cansaço, dificuldade e risco. Essa equipe mostra que tem suportado essas dificuldades e esses riscos sem se apropriar disso como um preparo e um cuidado em Saúde Mental, mas com o sentido de ser o seu "papel".

Vanessa trouxe, nesse momento, o sentido de que o tempo que a equipe está formada a ajuda a criar vínculos, conhecer seus pacientes e, principalmente, a experiência 
permite a identificação do adoecimento e o reconhecimento da mudança do comportamento dessas pessoas.

(pg. 95 linha 447 até 480 - equipe amarela)

JOANA: Então eu acredito que o papel do PSF é muito importante nessas áreas, porque eles pedem nós estamos lá, parece o salva vidas deles... Então a gente vai, corre, ajuda. (...) Então com a vinda do PSF melhorou muito, porque a gente cria o vínculo e muito com a população... porque tudo eles já sabem onde socorrer né...

LIA: Eles já sabem onde correr.

MARTA: Onde pedir...

\section{$(\ldots)$}

VANESSA: Porque como a gente conhece as famílias, todos né, nosso PSF já faz 11 anos que existe, então a gente já conhece... Já faz 8 anos que a equipe foi formada, que ta com a mesma equipe. A gente conhece eles, e sabe assim... quando agente vai visitar, pela história, a gente até comenta. A gente passa pra Joana, fala que acha que a pessoa ta entrando em depressão. Quem da o diagnostico é o Dr, mas a gente acaba tendo essa visão, pela experiência, é onde a gente encaminha, marca uma consulta com o Dr. Porque a gente já vai percebendo que a pessoa ta depressiva. Tem uma na minha área mesmo que ta com problema de saúde, teve câncer na mama, e eu já to percebendo que por esse história, fez a reconstrução da mama, não deu certo, e a auto-estima dela ta lá embaixo, a gente tem percebido conversando que ela ta entrando em depressão mesmo, então já precisa de ajuda (...).

PESQUISADORA: Então, você está falando de identificar um problema de saúde mental, que você ta começando a perceber.

VANESSA: É. A gente acaba, pela experiência, por conhecer a pessoa, a gente... tem casos né, que a pessoa começa a demonstrar que ta ficando... não tá normal, não é o que era...que há alguma mudança e que pode ser algum problema como depressão ou não, as vezes só um problema momentâneo, familiar.

ANA: E quando a gente percebe a gente comenta, fala pra eles passarem com uma psicóloga, manda eles passarem com você, pergunta se não quer que a gente marque a consulta (...).

Quando a pesquisadora perguntou para a equipe o que eles sentem ao lidar com estes pacientes, eles esvaziaram os recursos já descritos e colocaram a equipe como frustrada e paralisada diante das necessidades que surgem em Saúde Mental. A escuta não foi reconhecida como uma ajuda e como um recurso existente nesta equipe. 
70 Resultados: Apresentação e Discussão

Parece ser desgastante e frustrante para a equipe pensar que estão dando o máximo de si, mas que isso não basta e não é suficiente para ajudar. Por isso a importância de que consigam reconhecer esta ajuda, não esvaziar o sentido delas e conseguir reconhecer que o que fazem são ações concretas e que já podem ajudá-las.

(pg. 95 linha 484 até pg. 96 linha 495 - equipe amarela)

PESQUISADORA: E quais são os sentimentos que surgem quando vocês atendem, lidam com uma pessoa com um problema de saúde mental?

LIA: Na verdade eu acho assim, quando você consegue fazer alguma coisa você sente um alivio que você conseguiu fazer alguma coisa, conseguiu resolver, mas quando você não consegue nada fica a frustração...

TATIANA: Não tem o que fazer...

LIA: É que assim, você não tem o que fazer e você fica assim...frustrada né...

VANESSA: Sabe que tem que ajudar mas...

\section{LIA: Não tem como...}

TATIANA: Porque eles procuram muito a gente principalmente porque a gente dá atenção, a gente escuta né e eles acham que a gente vai poder ajudar, resolver tudo e a gente não tem estrutura, não tem como resolver e a vezes passa pra gente mesmo o problema...

Ao fim da entrevista, a pesquisadora perguntou para a equipe o que achou da conversa e eles falaram sobre o sentido do desabafo, que produziram algo que estava precisando ser dito, ser colocado para fora. Zulmira disse que todo o grupo pensava igual, talvez pela facilidade com que a conversa ocorreu, com uma construção de sentidos em conjunto e com um compartilhamento de idéias e experiências.

Tatiana falou que o ponto principal deste desabafo foi a falta. Ela falou do sentido da falta estar presente desde a família até a estrutura do Município. Lia complementou falando do sentido do cuidado em Saúde Mental como a existência de vários fatores interligados e Vanessa concluiu dizendo que ainda existem muitas barreiras.

Este fim de entrevista permitiu à pesquisadora perceber que aquele momento de troca de idéias e construção de novos sentidos sobre o trabalho de uma Equipe de Saúde da Família possibilitou que esses trabalhadores repensassem suas ações, suas formas de 
atuação e falassem sobre angústias e dificuldades que estão presentes no dia a dia de trabalho.

(pg. 97 linha 584 até pg. 98 linha 642 - equipe amarela)

PESQUISADORA: O que vocês acharam dessa nossa conversa?

ZULMIRA: Acho que a gente pensa tudo igual...

(risos)

JOANA: Foi mais um desabafo...

LIA: É foi um desabafo...

TATIANA: O ponto principal é esse, a falta de estrutura, desde a família até no município, tudo ta faltando..tudo...

LIA: $\mathrm{Eu}$ acho que teria que ta tudo interligado, cultura, social, esporte, tudo...a saúde, tudo interligado pra poder desenvolver algum projeto, pra eles terem uma ocupação...

VANESSA: Ficou de formar o grupo da hidroginástica né, e nada, ta parado... Projetos existem, só que esses projetos não são realizados, não tem o desenvolvimento deles na prática...

LIA: Se tivesse muitas pessoas já estariam bem melhores...

VANESSA: Muitas barreiras...

(silêncio)

ANA: Pra tudo...

JOÃO: Isso é geral...

(silêncio)

JOANA: Acho que é isso né...

(silêncio)

LIA: Acho que sim... Espero que a gente tenha ajudado.

PESQUISADORA: Gostaria de agradecer, acho que a discussão foi muito rica... Muito obrigada.

JOANA: Acho que esse tipo de reunião a gente tinha que ter quinzenal...

A última fala da entrevista, na voz de Joana, mostrou a necessidade de um espaço onde possam falar mais vezes sobre suas rotinas de serviços, dificuldades encontradas. Ela, 
72 Resultados: Apresentação e Discussão

neste momento, conseguiu identificar algo que falta para a equipe poder desabafar e cuidar de suas próprias angústias.

Para a pesquisadora, a possibilidade de ter um espaço de conversa onde a equipe possa falar sobre aquilo que está conseguindo fazer, sobre suas dificuldades e sobre aquilo que gostaria de desenvolver pode ser uma forma de tranquilizá-los e motivá-los para continuar ajudando e cuidando destes pacientes, dentro do possível e esperado de uma Equipe de Saúde da Família. 


\section{CONSIDERAÇÕES FINAIS}

Este estudo possibilitou a construção de novas descrições para as ações envolvendo a saúde mental que são desempenhadas pelos profissionais da ESF do Município de Serra Azul. $\mathrm{Na}$ análise, foram trazidos entendimentos e sentidos construídos pelo grupo dentro de um contexto específico e que descrevem o olhar da pesquisadora, relativo a essas equipes.

O "discurso da falta" atravessou a conversa da equipe, que apontou a ausência de recursos para conseguirem atuar melhor com os pacientes com problemas de Saúde Mental. Dessa forma, não levou em conta aquilo que já é feito por eles.

Esta construção de sentidos em cima das faltas caracterizou um discurso paternalista, em que seria necessário ter algo para dar e como não tem, produziram o discurso da falta.

A metáfora da entrevista parece ter sido "Como não temos algo, tal coisa não pode" e assim a equipe não conseguiu se responsabilizar por suas ações, ficou presa ao discurso de que precisam do outro, do que falta e se colocou numa condição paralisante.

A equipe ficou presa a idéia de ter que encaminhar estes pacientes aos serviços especializados e não pôde perceber o trabalho já realizado por ela neste tipo de atenção.

A equipe falou sobre várias formas de atuação com esses pacientes, citando como exemplos: ações de continência na transferência de pacientes, a percepção de que benefícios sociais para um casal de irmãos trariam uma melhor convivência familiar, acompanhamento terapêutico em relação à aderência a medicação e a conscientização familiar sobre o tratamento da doença mental

Todas essas ações foram esvaziadas de sentido, já que a equipe parece ter enxergado tais ações como insuficientes, incompletas.

Apesar de desempenharem tais ações, complexas e desgastantes, esta equipe não foi preparada para lidar com os desgastes físicos e emocionais gerados por elas. A conversa produzida pela equipe parece ter sido importante para despertar tais fragilidades, que apontam a necessidade da equipe também receber tratamento e cuidado.

O desgaste fica maior ainda quando estas equipes sentem que estão dando tudo de si e sentem isso como nada, como algo insuficiente e sem seu real valor. Esse maneira de se enxergarem impotentes paralisa o sistema e os colocam dentro do "saco" da falta, do lugar vazio. 
O pedido de atendimento, vindo de um dos profissionais entrevistados, mostrou à pesquisadora que a equipe percebe seu sofrimento e a necessidade de desenvolver um manejo instrumental de suas ansiedades, como apontado por Gonçalves (2000).

Assim como os familiares, que as vezes recebem atendimento em grupos de apoio, que os ajudam a lidar com o desgaste e sofrimento vindos do contato próximo, a equipe também precisa de cuidados e de espaço onde possa olhar para os limites de sua atuação e para si, enxergando não os profissionais, mas as pessoas existentes ali.

$\mathrm{Na}$ introdução foi apresentada a discussão de Scóz e Fenili (2003) sobre a necessidade emergente da inserção da saúde mental na ESF pelo fato do aumento dos transtornos psíquicos leves. Esta demanda foi trazida pela equipe, que descreveu pacientes adoecidos mentalmente, que abusam dos medicamentos psiquiátricos e que não aderem aos tratamentos em grupo e psicoterapêuticos.

Rabelo e Tavares (2008) discutem a importância das novas práticas em saúde para suprir as deficiências das equipes da ESF, que são influenciadas pelo modelo biomédico. Este modelo influenciou a formação de uma forte cultura individualista, que fundamenta ações tecnicistas e relações hierárquicas.

Camargo-Borges e Mishima (2009) apresentam as dificuldades de implementações de intervenções dialógicas, que buscam superar este paradigma hegemônico moderno da saúde, e valorizam as intervenções com foco na interação e no processo conversacional.

As autoras falam da dificuldade na adesão a essas intervenções pela formação tecnicista do trabalhador de saúde, que se sente inseguro e despreparado para uma prática mais relacional.

Algumas posturas são sugeridas por vários autores e apresentadas por CamargoBorges e Mishima (2009) para dar visibilidade às propostas de mudanças das práticas em saúde.

\footnotetext{
“A postura de curiosidade (Cecchin, 1998) fala do estabelecimento de um interesse genuíno e de um envolvimento nas histórias contadas pelos participantes. A curiosidade sobre uma história permite explorar mais seu acontecimento e interpretação, ampliando a possibilidade de entendimentos e de vislumbre de outras faces da mesma questão" (CAMARGO-BORGES; MISHIMA, 2009, p.16).
} 
A mudança de postura é uma das formas de demonstrar que os profissionais valorizam o encontro e a interação com os pacientes e que se sentem corresponsáveis pelas mudanças que propõem a eles.

Este trabalho mobilizou na pesquisadora a disposição para poder trabalhar com essas equipes e ajudá-las a construir novas descrições das suas ações e, com isso, poder criar um ambiente onde tanto o profissional quanto o usuário possam estar permanentemente em diálogo, buscando alternativas para lidar com as questões de saúde (CAMARGO-BORGES; MISHIMA, 2009).

Após analisar as entrevistas, a pesquisadora pôde concluir que à medida que esses trabalhadores se empoderarem de seus recursos, poderão ajudar os pacientes a também reconhecerem seus próprios recursos, através de espaços coletivos de interação.

No entanto, este é um trabalho que demanda tempo e vontade política dos gestores da saúde no município para a instituição de um processo de trabalho integrado.

A equipe mostrou ser capaz de identificar sintomas, estabelecer vínculos, encaminhar pacientes quando necessário e, principalmente, realizar escuta. Mas essas ações não foram entendidas como recursos pela equipe e a pesquisadora se perguntou o que foi oferecido a essas equipes para que pudessem reconhecer tais ações como recursos?

É de se esperar que estas equipes não estejam preparadas para identificar tais recursos, já que não foram oferecidos meios para tal reconhecimento. A maneira como descrevem e enxergam os pacientes também é fruto de um desconhecimento sobre os sintomas dos transtornos mentais. Quando a falta de vontade, a prostração e o desinteresse puderem ser vistos como parte da doença, a equipe poderá agir e se relacionar de outra forma com esses pacientes.

A partir do momento que estas equipes puderem reconhecer o trabalho que já fazem, poderão, como cidadãos, reivindicar por políticas públicas que também colaborem no cuidado ao doente mental.

É preciso que a equipe saia da postura de achar que está nas mãos dos outros aquilo que pode beneficiá-la e acreditar que novas práticas em saúde também podem surgir das suas próprias descrições.

Este trabalho mostrou-se importante também para que a pesquisadora, do lugar de Psicóloga do Município, pudesse repensar suas práticas e buscar capacitar essas equipes para continuarem a desempenhar seu trabalho com mais preparo e conhecimento. 
76 Considerações finais

A criação de espaços de conversa onde estas equipes possam reconhecer seus recursos, trabalhar suas ansiedades e dar novas descrições para suas ações contribuirá para melhorar a atendimento em Saúde Mental na Atenção Básica. 


\section{REFERÊNCIAS}

AMARANTE, P D. C. O homem e a serpente: outras histórias para a loucura e a psiquiatria. Rio de Janeiro: Editora Fiocruz, 1996.

(Coord.). Saúde Mental, políticas e instituições: programa de educação à distância. Rio de Janeiro: FIOTEC/FIOCRUZ, 2003.

BAHIA PEREIRA, W. A. Um psiquiatra, um projeto, uma comunidade. In: Jatene AD, Lancetti A, Mattos SAF. Saúde loucura: saúde mental e saúde da família. São Paulo: Hucitec; 2000. p. 95-102.

BENEVIDES, L. L. M. G. A função de publicização do acompanhamento terapêutico na clínica: O contexto, o texto e o foratexto do AT. 2007. 184f. Dissertação (Mestrado em Psicologia). Universidade Federal Fluminense, Niterói, 2007.

BRASIL. Ministério da Saúde. Legislação. Normas básicas do SUS, Brasília, 1990. Lei 8080/90. Disponível em: https://www.planalto.gov.br/ccivil_03/leis/18080.htm Acesso em: out. 2008.

Ministério da Saúde. Saúde da Família: uma estratégia para a reorganização do modelo assistencial. Brasília (DF): MS; 1997.

Ministério da Saúde. Secretaria Executiva. Sistema Único de Saúde (SUS): princípios e conquistas.Brasília: Ministério da Saúde, 2000. Disponível em: http://www.bvsms.saude.gov.br/bvs/publicacoes/sus_principios.pdf Acesso em: jun. 2009.

. Ministério da Saúde. O Programa de Saúde da Família e a Atenção Básica no Brasil. Brasília-DF, $2002 . \quad$ Disponível em: http://www.repositorio.aev.edu.br/files/c5fb9c9e469dc39f8ac68defd7ed.pdf Acesso em: jun. 2009.

Ministério da Saúde. Saúde Mental e Atenção Básica: o vínculo e o diálogo necessários. Coordenação de Saúde Mental e Coordenação de Gestão da Atenção Básica, 2003. Disponível em: http://www.portal.saude.gov.br/portal/arquivos/pdf/diretrizes.pdf Acesso em: ago. 2009.

. Ministério da Saúde. Secretaria de Atenção à Saúde.DAPE. Coordenação Geral de Saúde Mental. Reforma psiquiátrica e política de saúde mental no Brasil. Documento apresentado à Conferência Regional de Reforma dos Serviços de Saúde Mental : 15 anos depois de Caracas. OPAS. Brasília, 2005. Disponível em: http://www.portal.saude.gov.br/portal/arquivos/pdf/Relatorio15\%20anos\%20Caracas.pdf Acesso em: out. 2008.

Ministério da Saúde. Secretaria de Vigilância em Saúde. Secretaria de Atenção à Saúde. Política nacional de promoção da saúde / Ministério da Saúde, Secretaria de Vigilância em Saúde, Secretaria de Atenção à Saúde. - Brasília : Ministério da Saúde, 2006a. Disponível em: http://portal.saude.gov.br/portal/arquivos/pdf/pactovolume7.pdf Acesso em: ago. 2009. 
. Ministério da Saúde. Secretaria de Atenção à Saúde. Núcleo Técnico da Política Nacional de Humanização. Humaniza SUS: documento base para gestores e trabalhadores do SUS. 3 ed. Brasília: Editora do Ministério da Saúde, 2006b. Disponível em: http://www.pqv.unifesp.br/conceitodeclinicaampliadaadail.pdf Acesso em: jun. 2011.

Ministério da Saúde. Secretaria de Atenção à Saúde. Núcleo Técnico da Política Nacional de Humanização. Clínica ampliada, equipe de referência e projeto terapêutico singular. $2^{\mathrm{a}}$ ed. Brasília: Ministério da Saúde, 2007. Disponível em: http://bvsms.saude.gov.br/bvs/publicacoes/clinica_ampliada_equipe_referencia_2ed_2008. pdf Acesso em: jun. 2009.

- Secretaria de Estado da Saúde de São Paulo. Qualis Mais: Oficina de Programação e Planejamento Estratégico da Atenção Básica. São Paulo, Junho de 2008. Disponível em: http://www.saude.sp.gov.br/resources/gestor/projetos/guia_do_facilitador_da_oficina_dea b_sp_final_05_06.pdf Acesso em: ago. 2009.

- Ministério da Saúde. Secretária de Atenção à Saúde. Departamento de Atenção Básica. Diretrizes do NASF. Cadernos de Atenção Básica n. 27. Brasília-DF, 2009. Disponível

http://bvsms.saude.gov.br/bvs/publicacoes/caderno_atencao_basica_diretrizes_nasf.pdf Acesso em: fev. 2010.

. Ministério da Saúde. Secretaria de Atenção à Saúde. Núcleo Técnico da Política Nacional de Humanização. Humaniza SUS: documento base para gestores e trabalhadores do SUS. 4 ed. Brasília: Editora do Ministério da Saúde, 2010a. Disponível em: http://bvsms.saude.gov.br/bvs/publicacoes/humanizasus_documento_gestores_trabalhador es_sus.pdf Acesso em: jul. 2011.

. Ministério da Saúde. Secretaria de Vigilância em Saúde. Secretaria de Atenção à Saúde. Política Nacional de Promoção da Saúde / Ministério da Saúde, Secretaria de Vigilância em Saúde, Secretaria de Atenção à Saúde. - 3. ed. - Brasília : Ministério da Saúde, 2010b. Disponível em: http://bvsms.saude.gov.br/bvs/publicacoes/politica_nacional_promocao_saude_3ed.pdf Acesso em: out. 2010.

CAMARGO-BORGES, C. Sentidos de saúde/doença produzidos em grupo numa comunidade alvo do Programa de Saúde da Família (PSF). 2002. 161f. Dissertação (Mestrado em Psicologia) - Faculdade de Filosofia Cinências e Letras, Universidade de São Paulo, Ribeirão Preto, 2002.

CAMARGO-BORGES, C.; MISHIMA, S.; MCNAMEE, S. Da Autonomia à Responsabilidade Relacional: Explorando novas inteligibilidades para as práticas de saúde. Gerais: Revista Interinstitucional de Psicologia. v. 1, n. 1, p. 8-19, 2008.

CAMARGO-BORGES, C.; MISHIMA, S. A Responsabilidade Relacional como Ferramenta Útil para a Participação Comunitária na Atenção Básica. Saúde Soc. São Paulo, v.18, n.1, p. 29-41, 2009. 
CAMPOS, G. W. S. A Reforma Sanitária Necessária. In: BERLINGURE, G; TEIXEIRA, S. M. F; CAMPOS, G. W. S. (Orgs.) Reforma Sanitária- Brasil e Itália. São Paulo: Hucitec, 1988. 207p.

CAMPOS, G. W. S., DOMITTI, A. C. Apoio matricial e equipe de referência: uma metodologia para a gestão do trabalho interdisciplinar em saúde. Cad. Saúde Pública, Rio de Janeiro, v. 23, n. 2, p. 399-407, fev., 2007.

COHN, A. A saúde na previdência social e na seguridade social: antigos estigmas e novos desafios. In: COHN, A.; ELIAS, P. E. Saúde no Brasil: políticas e organização de serviços. $3^{\text {a }}$ Ed. São Paulo: Cortez, 1999.

CONSELHO NACIONAL DE SECRETÁRIOS DE SAÚDE (BRASIL). Atenção primária e promoção da saúde. Brasília, DF : CONASS, 2007. 228 p. (Coleção progestores para entender a gestão do SUS, v.8)

DELGADO, P. G. G.; SCHECHTMAN, A.; WEBER, R.; AMSTALDEN, A. F.; BONAVIGO, E.; CORDEIRO, F.; PORTO, K.; HOFFMANN, M. C. C. L.; MARTINS, R.; GRIGOLO, T. (2007). Reforma psiquiátrica e política de saúde mental no Brasil. Conferência Regional de Reforma dos Serviços de Saúde Mental: 15 anos depois de Caracas. In. Mello, M.F., Mello, A.A.F., Kohn R. (Orgs.). Epidemiologia da saúde mental no Brasil. Porto Alegre: Artmed., 2007. p. 39-83.

FIGUEIREDO, M. D., CAMPOS, R. O. Saúde Mental e Atenção Básica à Saúde: a apoio matricial na construção de uma rede multicêntrica. Saúde em Debate, Rio de Janeiro, v. 32, n. 78/79/80, p. 143-149, jan./dez. 2008.

FIORATI, R. C. Acompanhamento Terapêutico: uma estratégia terapêutica em uma unidade de internação psiquiátrica. 2006. 145f. Dissertação (Mestrado). EERP-USP. Ribeirão Preto, 2006.

GERGEN, K. J. The social constructionist movement in modern psychology. American Psychologist, Washington D. C., n. 40, p. 266-275, 1985.

An Invitation to Social Construction. Londres: Sage, 2009.

GONÇALVES, P. L. A unidade de referência e a equipe volante. In: Jatene AD, Lancetti A, Mattos SAF. Saúde loucura: saúde mental e saúde da família. São Paulo: Hucitec; 2000. p. 109-116.

GONDIM, S. M. G. Grupos focais como técnica de investigação qualitativa: desafios metodológicos. Paidéia. Ribeirão Preto, v. 12, n.24, p. 149-161, 2002.

GUANAES, C. A construção da mudança em Terapia de Grupo: um enfoque construcionista social. São Paulo: Vetor, 2006.

GUANAES, C. JAPUR, M. Sentidos de Doença Mental em um Grupo Terapêutico e sua Implicações. Psicologia: Teoria e Pesquisa. Brasília, v.21, n.2, maio/ago, 2005. 
. Contribuições da poética social à pesquisa em psicoterapia de grupo. Estudos

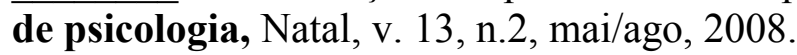

GUI, R. T. Grupo focal em pesquisa qualitativa aplicada: intersubjetividade e construção de sentido. Psicologia, Florianópolis - SC, v. 3, n. 1, p. 135-159, 2003.

IBGE. Instituto Brasileiro de Geografia e Estatística. Disponível em: http://www.ibge.gov.br/home/estatistica/populacao/censo2010/tabelas_pdf/total_populacao _sao_paulo.pdf. Acesso em: 4 Abr. 2011.

KIND, L. Notas para o trabalho com a técnica de grupos focais. Psicologia em Revista, Belo Horizonte, v. 10, n. 15, p. 124-136, jun. 2004.

LANCETTI, A. Saúde mental nas entranhas da metrópole. In: JATENE A. D.; LANCETTI A.; MATTOS S. A. F. Saúde loucura: saúde mental e saúde da família. São Paulo: Hucitec; 2000. p. 11-52.

LLANES, G. D. Los grupos focales. Su utilidad para El médico de família. Rev. Cubana Med. Integr., Habana, v. 21, n. 3-4, may./ago. 2005.

IERVOLINO, SA.; PELICIONI, MCF. A utilização do grupo focal como metodologia qualitativa na promoção da saúde. Rev Esc Enf USP, v. 35, n. 2, p.115-121, jun, 2001.

MARQUi, A. B. T., JAHN, A. C., RESTA, D. G., CAlOMÉ, I. C. S., ROSA, N., ZANON, T. Caracterização das equipes da saúde da família e de seu processo de trabalho.

Rev. Esc. Enferm. USP; v. 44 n. 4, p. 951-61. 2010.

MATTOS, R. A. Os sentidos da integralidade: algumas reflexões acerca de valores que merecem ser definidos. In: PINHEIRO, R.; MATTOS, R. A. Os sentidos da integralidade na atenção e no cuidado à saúde. Rio de Janeiro: ABRASCO, p. 39-64, 2001.

MENDES, E.V. Os grandes dilemas do SUS. Salvador: Casa da Qualidade Editora, 2001.

NUNES, E. D. Sobre a história da Saúde Pública: idéias e autores. Ciência e Saúde Coletiva, v. 5, n. 2, p. 251-264. 2000.

OMS. Relatório Mundial de Saúde. Saúde Mental: nova concepção, nova esperança. Genebra: 2001.

. Programas e projetos: saúde mental. Disponível em: http://www.who.int/mental_health/en/ Acesso em: out. 2008.

PAULIN, L. F.; TURATO, E. R. Antecedentes da Reforma Psiquiátrica no Brasil: as contradições dos anos 1970. História, Ciências, Saúde- Manguinhos, Rio de Janeiro, v.11, n. 2, p. 241-258, 2004.

PAULUS JUNIOR, A.; CORDONI JUNIOR, L. Políticas públicas de saúde no Brasil. Revista Espaço para a Saúde, Londrina, v. 8, n.1, p.13-19, dez. 2006. Disponível em: http//:www.ccs.uel.br/espacoparasaude/v8n1/v8n1_artigo_3.pdf Acesso em: abr. 2010. 
PEREIRA, MAO et al. Saúde mental no Programa de Saúde da Família: conceitos dos agentes comunitários sobre o transtorno mental. Rev Esc Enferm USP. v. 41, n. 4, p. 567 $572,2007$.

PeSsini, L. BARCHIfontAine, C. P. Problemas Atuais de Bioética. São Paulo: Loyola, 2007.

RABELO, I. V. M., TAVARES, R. C. Homens-carrapatos e suas mulheres: relato de experiência em Saúde Mental na Estratégia Saúde da Família. Saúde em Debate, Rio de janeiro, v. 32, n. 78/79/80, p. 133-142, jan./dez. 2008.

RASERA, E. F. Grupo de apoio para pessoas portadoras do HIV/Aids: negociando diferenças. 1999. 130 f. Dissertação (Mestrado). Faculdade de Filosofia, Ciências e Letras de Ribeirão Preto, Universidade de São Paulo, Ribeirão Preto, 1999.

RASERA, E. F., JAPUR, M. Grupo como construção social: aproximações entre construcionismo social e terapia de grupo. São Paulo: Vetor, 2007.

RODRIGUEZ NETO, E. A Reforma Sanitária e o Sistema Único de Saúde. In Brasil: Ministério da Saúde. Projeto Nordeste Informação Educação e Comunicação/ Incentivo a Participação Popular e ao SUS. Brasília, 1994.

SCÓZ, T.M.X.; FENILI, R.M. Como desenvolver projetos de atenção à saúde mental no programa de saúde da família. Revista Eletrônica de Enfermagem, v. 5 n. 2 p. 71 - 77, 2003. Disponível em http:/www.fen.ufg.br/revista. Acesso em: ago. 2009.

SEABRA, D.C. O agente comunitário de saúde na visão da equipe multiprofissional. 2006.133f. Dissertação (Mestrado) - Departamento de Medicina Social da Faculdade de Medicina da Universidade de São Paulo de Ribeirão Preto, Ribeirão Preto, 2006.

SILVA, J. A., DALMASO, A. S. W. O agente comunitário de saúde e suas atribuições: os desafios para os processos de formação de recursos humanos em saúde. InterfaceComunic, Saúde, Educ, v. 6, n. 10, p. 75-96, fev 2002.

SILVEIRA, L. C.; BRAGA, V. A. B. Acerca do conceito de loucura e seus reflexos na assistência de saúde mental. Rev. Latino-Am. Enfermagem. v.13 n.4, Ribeirão Preto, jlu./ago. 2005.

SOUSA, M. F. A cor-agem do PSF. São Paulo: HUCITEC, 127p. 2001.

SOUZA, R. C. Produção de sentidos por profissionais de saúde da família acerca do doente mental e dos cuidados a ele dirigidos. 2004. $192 \mathrm{f}$. Tese (Doutorado) Programa de Pos Graduação em Enfermagem, Escola de Enfermagem de Ribeirão Preto, Universidade de São Paulo, Ribeirão Preto, 2004.

SPINK, M. J.; FREZZA, R. M. Práticas discursivas e produção de sentidos: a perspectiva da psicologia Social. In: SPINK; M. J. (Org). Praticas discursivas e produção de sentidos no cotidiano. Aproximações teóricas e metodológicas. 2 ed. São Paulo: Cortez Editora, p. 17-39. 2000. 
SPINK, M. J.; LIMA, H. Rigor e visibilidade: a explicação dos passos da interpretação. In: SPINK; M. J. (Org). Praticas discursivas e produção de sentidos no cotidiano. Aproximações teóricas e metodológicas. 2 ed. São Paulo: Cortez Editora, p. 93-123. 2000.

SPINK, M. J.; MENEGON, V. M. A pesquisa como prática discursiva: superando os horrores metodológicos. In: SPINK; M. J. (Org). Praticas discursivas e produção de sentidos no cotidiano. Aproximações teóricas e metodológicas. 2 ed. São Paulo: Cortez Editora, p. 63-92. 2000.

TENÓRIO, F. A Reforma psiquiátrica da década de 1980 aos dias atuais: história e conceitos. História, Ciências, Saúde- Manguinhos, Rio de Janeiro, v. 9, n.1, p. 25-59, jan/abr. 2002.

TSU, T. M. J. A., TOFOLO, V. Concepções etiológicas de pacientes psiquiátricas sobre doença mental. Psicol. USP, São Paulo, v.1 n. 2, p.155-166, 1990.

VASCONCELOS, E. M. Educação popular e a atenção à saúde da família. São Paulo: Hucitec, 1999.

WEBER, C. A. T. Programa de Saúde da Família: educação e controle da população. Porto Alegre, RS: AGE, 2006.

ZIMMERMANN, M. H. ; MARTINS, P. L. O. . Grupo Focal Na Pesquisa Qualitativa: Relato De Experiencia.. In: VIII Congresso Nacional de educação - EDUCERE e III Congresso Ibero-Americano sobre violência nas escolas - CIAVE, 2008, Curitiba. VIII Congresso Nacional de educação - EDUCERE e III Congresso Ibero-Americano sobre violência nas escolas - CIAVE. Curitiba : Editora Champagnat, v. 1, p. 116-125. 2008. 


\section{APÊNDICES}

\section{Apêndice 1}

\section{Roteiro de Entrevista}

1) O que vocês entendem por saúde mental?

2) Vocês acham que a saúde mental é uma área para ser tratada pelo Programa de Saúde da Família? Por quê?

3) O que seria necessário para que vocês se sintam preparados para atender casos de saúde mental?

4) Vocês passaram por algum treinamento para lidar com casos que envolvam saúde mental? Se sim, como foi?

5) O que vocês acham de ser discutido nas reuniões da ESF sobre a saúde mental da comunidade atendida?

6) Como vocês procedem quando percebem um paciente ou uma família com questões de saúde mental?

7) Como vocês se sentem ao atender um paciente com demanda para saúde mental? 


\section{Apêndice 2}

\section{Termo de Consentimento Livre e Esclarecido}

(De acordo com a resolução ${ }^{\circ}$ 196/96 sobre pesquisa envolvendo seres humanos do Conselho Nacional de Saúde - Ministério da Saúde - Brasília - DF)

Meu nome é Mariana de Oliveira Pasqualin Ribeiro, sou psicóloga e aluna do programa de Mestrado em Saúde na Comunidade da Faculdade de Medicina de Ribeirão Preto da Universidade de São Paulo. Estou realizando uma pesquisa intitulada "Recursos e Necessidades de profissionais da Estratégia Saúde da Família para lidar com questões relacionadas à Saúde Mental.”, orientado pela Profa. Dra. Maria do Carmo Gullaci CacciaBava. O meu objetivo nesta pesquisa é construir sentidos, através de entrevistas, sobre os recursos e necessidades de profissionais da Estratégia Saúde da Família para lidar com questões de Saúde Mental.

A sua colaboração será participar de uma entrevista de grupo focal através da qual falaremos sobre como a Saúde Mental está inserida no trabalho da equipe de Saúde da Família. A entrevista acontecerá em grupo, em local seguro e privado para preservar a integridade da equipe e ocorrerá após um contato inicial com o pesquisador. Ela será gravada para transcrição posterior. Ao final do estudo os documentos e gravações serão armazenados em lugar seguro e reservado e ficarão sob a minha responsabilidade.

É importante esclarecer que, em hipótese alguma, sua identidade será revelada, uma vez que nos relatos da pesquisa, publicações e arquivamentos, serão tomados os devidos cuidados para que todas as pessoas citadas não sejam identificadas. Após seu relato, disponibilizarei a você o material caso deseje modificar algo ou desistir da pesquisa.

Para que eu possa realizar esta pesquisa, preciso que você assine este documento mostrando sua livre e espontânea decisão em participar, sendo que você tem o direito de desistir da entrevista ou não responder a algumas perguntas sem explicitar seus motivos para a desistência. Este termo será assinado por mim e por você sendo que cada uma de nós ficará com uma via. Caso tenha qualquer dúvida sobre o estudo, estarei disponível pelo telefone: (16) 9171-9045.

\section{Declaração de Consentimento}

$\mathrm{Eu}$,

R.G. $\mathrm{n}^{\circ}$, declaro estar devidamente informado sobre a minha participação na pesquisa intitulada "Recursos e Necessidades de profissionais da Estratégia Saúde da Família para lidar com questões relacionadas à Saúde Mental.”Após minhas dúvidas terem sido devidamente esclarecidas pelo pesquisador, declaro que estou de acordo em participar desta pesquisa sobre a responsabilidade da psicóloga Mariana de Oliveira Pasqualin Ribeiro. Minha participação é livre e espontânea conforme foi exposto no termo de consentimento. Poderei interromper a pesquisa a qualquer momento, desistindo de participar. Eu permito a divulgação dos resultados estando ciente que a minha identidade será mantida em sigilo.

Serra Azul, de 2010.

Assinatura do entrevistado: Assinatura do pesquisador: 
ANEXOS

ANEXO A

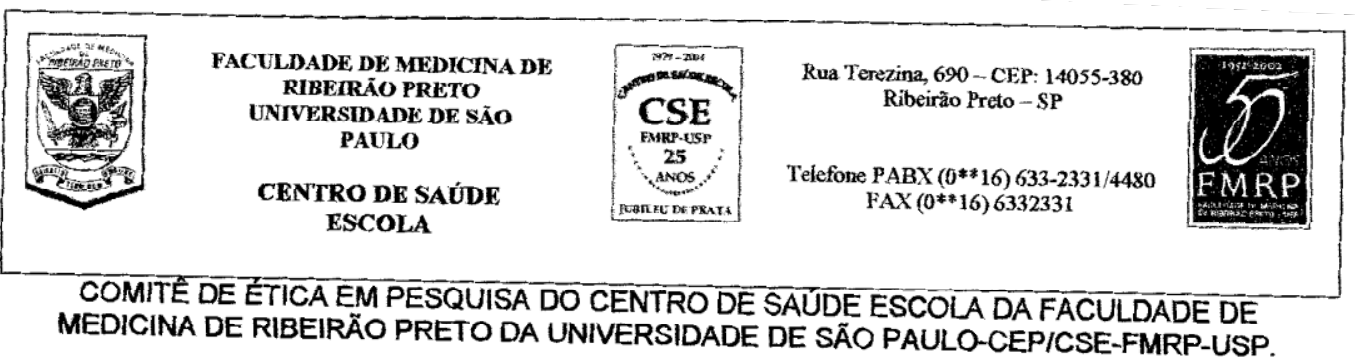

Ribeirão Preto, 14 de outubro de 2009.

Of. № 215/09/COORD.CEP/CSE-FMRP- USP.

Senhora Professora,

Temos a grata satisfação de comunicar que o senhor coordenador do Comitê de Ética em Pesquisa do Centro de Saúde Escola da Faculdade de Medicina de Ribeirão Preto da Universidade de São Paulo, em reunião, realizada no dia 13 de outubro de 2009, analisou e apreciou o parecer, referente ao projeto de pesquisa: "Percepção sobre saúde mental pela equipe de Saúde da Família de Serra Azul/SP.", protocolo $n^{\circ} .330 / C E P-C S E-F M R P-U S P$,

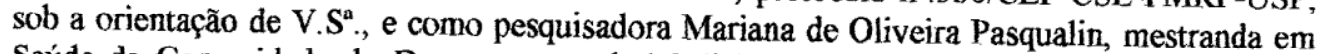
Saúde da Comunidade do Departamento de Medicina Social da Faculdade de Medicina de Ribeirão Preto-USP, foi aprovado ad-referendum.

Em atendimento à Resolução 196/96, deverá ser encaminhado a este CEP, o relatório final da pesquisa e a publicação de seus resultados.

No ensejo, renovamos os votos de estima e consideração, despedimo-nos. Atenciosamente,

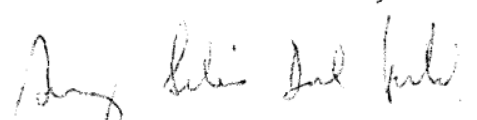

Prof. Dr. Amaury Lélis Dal Fabbro

Vice-Coordenador do CEP/CSE-FMRP-USP

Ilma. Sra.

Prof'. Dr ${ }^{a}$. Maria do Carmo G.G. Caccia-Bava

Departamento de Medicina Social da

Faculdade de Medicina de Ribeirão Preto-USP. 


\section{ANEXO B}

\section{ENTREVISTA EQUIPE AMARELA}

Pesquisadora: O que é saúde mental para vocês?

(silêncio)

Joana: Eu vou deixar vocês falarem.

(o grupo se olha, alguns risos)

Ana: Eu tenho vergonha (risos).

Zulmira: Fala Dr...

João: Primeiro tem que saber o que é o conceito de saúde né, tentar passar isso para área mental. O que é saúde ? É o bem estar físico, social... dentre outras coisas. E a saúde mental seria isso, a pessoa que está em plena capacidade, cognitiva, de não ter transtorno nenhum e várias coisas influenciam nisso. Desde a situação social... O pessoal a gente vê muito aqui em Serra Azul...Até outros fatores, a gente vê muito aqui o problema de droga, muito problema de etilismo e isso tudo interfere, problemas externos na saúde mental. As agentes comunitárias vêem isso todo dia, nas visitas...

Joana: E assim, na minha opinião, saúde mental além do que o Dr falou, a gente tem que ta equilibrada né, saúde mental pra mim é o que? É ter lazer, é ter a parte social, é ter esporte...É...Esporte inclui lazer já né...hum...Alimentação...Envolve tudo entendeu, o que eu penso é isso aí, você tem que estar toda equilibrada. A saúde tem que estar bem.

Vanessa: Moradia...

Joana: Moradia, tem que ter lazer...Tem que ter educação, então tudo correndo bem o individuo está bem mentalmente. É isso que eu penso. (silencio)

Vanessa: Hoje a maioria das pessoas que a gente vê que desenvolve um transtorno mental, geralmente você vai colher a história, lógico que tem fatores hereditários, mas muitas vezes é por problema social realmente, por falta de moradia, por desemprego, por ...é...que entra a depressão né, hoje muitas pessoas tem a depressão por conta disso, eu acho que busca algo ou quer algo e não consegue e se frustra e vem a depressão que é um transtorno e pode desenvolver outras coisas, outras doenças. Eu vejo aí...

(silencio maior)

Pesquisadora: O que é importante é a opinião de vocês...

Joana: Não existe certo e errado.

Ana: Eu vejo que parece que ta tendo muita é...na atualidade agora ta tendo muita doença relacionada a saúde mental né, stress, depressão e eu acho que é um problema também do capitalismo, porque é o consumismo, a gente quer ter, as outras pessoas vivem bem e a gente assiste muita televisão, a gente quer ter o que vê na televisão e isso vai martelando na cabeça até o momento que a pessoa não consegue mais...devido ao emprego, não tem o emprego que queria ter e ta ficando muito difícil.

Lia: Aqui na cidade eu acho que ta tendo muito problema mental principalmente por causa do alcoolismo que é muito grande na nossa cidade. Por que? Não tem o que fazer na cidade, o que eles vão fazer? Vai pra bar, bebe bebe bebe e vai pra casa. Aí briga...Então eu acho que o que falta mesmo é um trabalho junto com o pessoal que ta ai desempregado, precisa de trazer mais coisa pra cidade pra tirar esse pessoal da rua né e tem muito adolescente bebendo muito também, por que? Não tem um esporte pra praticar, não tem um incentivo pra nada na cidade.

Ana: Cultura...

Vanessa: Não tem um lazer, a festa deles é churrasco... 
Lia: Churrasco e bebida. Então eles não tem nada, isso acarreta tudo no que, la na frente, que vai trazer problema psicótico, um monte de coisa...

Zulmira: Não é só a bebida, é a droga.

Joana: As vezes inicia pelo álcool e depois vai pra droga.

Zulmira: As vezes a pessoa usa a droga e não usa o álcool. Eu conheço varias pessoas aí, num bairro próximo que fumam droga, cheram tudo mas não usam o álcool não.

Tatiana: O pior que é a maioria dos jovens né.

Zulmira: A maioria, a grande maioria. $\mathrm{O}$ crescimento foi muito grande de uns 2 anos pra cá. Não tem uma pessoa na rua, que as vezes você olha e fala aquela pessoa não e de repente acaba descobrindo que ta usando droga também, aí tem também uma série de outras coisas, usa droga e ai sai por ai só pensa em fazer desavença, não só aqui em Serra Azul, é geral né. Pode ver aí as notícias tudo.

Pesquisadora: Então vocês estão relacionando o uso de álcool e drogas com a saúde mental, vocês acham que tem uma relação aí.

Lia: Tem.

Zulmira: A pessoa desequilibrada né, procura álcool, procura droga, procura só... Eles não tem assim onde recorrer pra se livrar, é difícil, chega pra nós lá, é difícil também, a gente não tem um lugar específico pra ta mandando, é complicado essa parte.

Vanessa: Eu acho...

Zulmira: Aqui tem que ter mais grupos, convidar mais os jovens pra participar de palestras, pra mostrar o que é errado, o que é certo, embora eles sabendo o que é certo e o que é errado. Hoje eles procuram fazer mais o que é errado do que é certo. Eu acho que falta um pouco de união, né? E chamar mais os jovens pra participar de palestras que eu acho que é importante. Tanto na escola, fazer um grupo, nos bairros também, você, talvez o Dr. Junto ali. Tenta mostrar pra eles, puxa eles. Eu acho importante isso.

Tatiana: $\mathrm{Eu}$ acho que tudo isso, resumindo, é falta né...Falta de coisas materiais, principalmente eu acho, pra mim, que é a estrutura familiar, ocasiona tudo isso entendeu? Já vem da família, já vem. Em relação aos jovens, cresce naquilo, pai, mãe, então eu acho que é isso que ocasiona tudo. Pra mim é.

João: Independente de ser a causa, o que a gente vê muito é que nunca tem um caso só numa família né. A gente tem família aí que mãe ta deprimida, pai ta deprimido... pai tem transtorno de ansiedade ou alguma coisa, o filho já está insatisfeito.

Joana: É.

João: Então vira uma coisa...a tal da síndrome do stress do cuidador. É a mesma coisa de cuidar de alguém acamado. Então não fica uma pessoa só doente. Aquele transtorno fica...pega a família inteira e não é difícil a gente ver isso lá, a gente ainda comenta e brinca, porque quando vem, "ah meu marido ta com problema" "minha esposa ta com depressão" "meu filho... ta em casa..." Aí é isso que eu tava falando, vai crescendo, não sei se é... mas vai crescendo nesse ambiente, e, o transtorno vai fazendo parte daquilo lá e você lida como uma coisa natural...

Tatiana: E hoje em dia tudo assim...é muita falta de amor, de carinho né, é muita...

João: E uma coisa que eu sinto muito, a gente sempre ta falando e não consegue passar pro pessoal é assim: "ai eu quero um remédio pra melhorar". Não existe isso, senão não era remédio era milagre né. Aí a gente conseguia cuidar de todo mundo. Então a pessoa quer melhorar mas assim, como eu vou explicar...Quer melhorar mas não quer que ela faça alguma coisa, quer que alguém faça isso pra ela.

Vanessa: Não colabora né.

João: Talvez isso seja até um mecanismo de desespero, de achar, "olha eu não tenho mais capacidade". E a gente vê isso em famílias inteiras, e não só... Pelo menos lá na nossa área, aí entra a bebida, entra a droga. 
Vanessa: E junto com isso, o álcool, a droga, já é um transtorno né...

João: O álcool é muito fácil de achar né...

Vanessa: Já se torna um transtorno mental porque uma pessoa dependente não ta mentalmente bem...

Pesquisadora: Então, dentro disso eu queria saber de vocês acham que a Saúde Mental é uma área pra ser tratada pelo Programa de Saúde da Família.

Joana: Com certeza.

Lia: Com certeza... Assim... não os casos surtados...

(risos)

João: Mas o começo acaba caindo lá. O começo acaba caindo lá.

Lia: É desde o princípio. A gente faz as visitas, você vê lá que tá precisando você vai agendar uma consulta né, pra ele. Ele passa com o Dr, o Dr. vai mandar ele lá pro grupo, pra alguma coisa tal, só que a partir do momento que a pessoa ta surtada eu acho que deveria ta vindo pra cá ( Unidade de Saúde).

Ana: É mas o PSF já cuida desses casos, porque o primeiro atendimento é lá.

Joana: É lá.

Ana: Então a gente marca a consulta, o paciente vai lá, o Dr. passa a medicação, que ele vê que o paciente precisa naquela hora, mas ele encaminha o paciente, então no caso, o que teria que ter em Serra Azul seria a Saúde Mental, pra ta todo mundo trabalhando junto com esses pacientes.

João: Mas eu acho assim, talvez esse trabalho do PSF a gente foge um pouco disso por causa da estrutura toda... tem que ter todo um trabalho de prevenção, lá atrás. A gente tenta prevenir pra não chegar a esse ponto.

Zulmira: Mas não tem como, ali virou um pronto atendimento. $\mathrm{O}$ pessoal chega e não aceita, não quer que agenda.

Vanessa: Por conta da Unidade aqui (UMS), eles aqui não tem uma base, aí a gente fica meio assim, a prevenção fica meio, passa um pouco por cima, por conta disso.

Joana: O que a gente observa também é que a gente propõe ajuda pra eles mas é que eles não aceitam entendeu? Que nem agora a Mariana ta atendendo lá com a gente, a gente marca e vai encima e a gente vê que eles não aparecem então eu acho que eles querem que caia uma coisa direta pra eles melhorarem. Eles não querem se ajudar. É que nem o Dr falou, eles não querem eles melhorarem, querem que a gente...Tem que partir deles também, não cabe só ao profissional. Que a gente fala "olha tem que fazer isso isso e isso" mas na hora do vamos ver eles acabam não fazendo. E acaba não indo procurar também né. João: Tem muitos que você fala "Olha então vamos começar com a Psicóloga e depois você volta..." Acabou aí.

Zulmira: Tem pessoas que as vezes o Dr encaminha pra psiquiatria e dali mesmo, saindo já fala "O médico ta achando que eu sou louco, eu não sou louco não" (risos). Eles não aceitam as vezes, não aceitam passar pelo psiquiatra. Já sai xingando ali mesmo. Desinteressado em se ajudar.

Joana: E tem outra coisa também, os sintomas a gente vê que é um problema mental, que é um doente mental, só que eles não acabam aceitando. Então eles começam a desenvolver vários sintomas e aí começam "Não é por causa disso, disso" Eles não aceitam, eles acham que ele tem algum problema físico mesmo entendeu.

Vanessa: Igual um da minha área né, uma pessoa lá, um jovem da minha área lá, que é transtorno mental, ele tem depressão, não sei, foi encaminhado, mas ele não aceita...

Joana: A família não aceita também.

Vanessa: Fala que a falta de apetite dele é porque ele tem alguma coisa no estômago. Chegou até ter que pedir endoscopia e não deu nada, não tem nada, os exames físicos dele normais. Realmente é a mente mesmo. 
Zulmira: Ali é a família toda.

João: Então é aquilo lá...

Zulmira: Acho que é hereditário... Não é hereditário, é social na realidade, porque já vem... familiar...

Joana: Tem um exemplo lá no PSF da... a Mariana até conhece, da Helena e do Otacílio, quando ta... que o problema social ta influenciando, porque lá é o problema social influencia $100 \%$, que ela não tem o dinheiro, aí ela vai lá, ela surta, ela dá o maior problema. Quando ela ta com dinheiro, que ela ta bem, que tem coisa pra comer, é tranqüilo.

João: Só briga quando ela ta com dinheiro e ele não ta, aí quem surta é ele. (muitos risos)

Ana: É o problema do capitalismo (risos).

Joana: É o capitalismo influenciando (risos). É o bendito dinheiro.

Pesquisadora: Vocês estão falando que a saúde mental é uma área para ser tratada pelo PSF, vocês acham que vocês estão preparados para isso?

Ana: Ah...Não

Joana: Eu acho que precisa ser capacitado.

Zulmira: Também acho.

Lia: De jeito nenhum.

Zulmira: Ontem mesmo eu fui na saúde mental, eu tava até comentando com a Joana hoje, que eu hoje to mal pra caramba sabe (risos).

Joana: É cansativo.

Zulmira: É cansativo, você acaba se cansando mentalmente. Sabe, assim, porque a gente ta acostumada a lidar aqui, de repente muda o quadro de vida, sabe, eu sou assim meio chorona, sou meia sentimental (risos). E eu fui lá ontem e nossa, voltei mal pra caramba. Aconteceu várias coisas ali que nossa eu pensei "Eu vou surtar" (risos). Eu acho que eu ainda não to preparada, acho que eu não to. Sinceramente.

Ana: Eu acho que eu sou meio hipocondríaca. Aconteceu alguma coisa eu penso, eu tenho medo de acontecer comigo sabe. A paciente minha teve câncer lá, eu fico "aí será que eu vou ter" Aí eu fico pensando essas coisas, ai quando eu vejo o paciente doente mental, eu morro de medo de ter doença mental, de ficar louca (risos).

Tatiana: Eu já não

Ana: Eu tenho medo de ficar, como é que eu vou fazer.

Tatiana: Eu já tenho vontade de ajudar. De poder fazer alguma coisa. Porque eu já passei por situação assim, de ajudar, meu irmão ficou com depressão muito forte, e eu ajudei muito ele assim, até ele ficar bom mesmo. Então eu acho assim, não sei, eu sinto vontade de ver aquela pessoa bem sabe, de poder ajudar, fazer alguma coisa. Eu já não tenho medo igual a Ana fala assim.

Ana: $\mathrm{Eu}$ tenho medo de ser futuramente, porque eu tenho parente que tem. Na minha família tem caso.

(risos)

Aí minha mãe fala que eu tenho um pezinho lá. Então, futuramente eu falo "Ai meu Deus se eu ficar doida". Essa é a preocupação.

Joana: Então, lá no PSF a gente atende esses casos, mas quando aparece muito, o que eu percebo é que chega no final do dia a gente ta esgotado.

João: Todo mundo

Joana: Estressado, então eu acho que é uma parte muito difícil pra ser trabalhado, e é o que a gente ta mais tendo, só que eu acho muito cansativo.

Lia: tem que estar preparado pra isso.

Joana: Sempre a pessoa volta, você vai lá no outro dia ela ta de volta, entendeu, é sempre a mesma coisa, e aí quem acaba adoecendo é os profissionais mesmo. 
Vanessa: Acaba que perece que não acha uma solução pra eles.

Joana: Eles mesmos não se ajudam.

Vanessa: É eles não se ajudam e a gente fica assim, sempre batendo na mesma tecla, falando a mesma coisa e eles não entendem e ai aonde a gente acaba se cansando, se estressando, porque não são só eles, tem outros problemas e aí fica difícil realmente.

Zulmira: Tem certos pacientes que a gente agenda a consulta, um dia antes, a hora que eu vou pegar as pastas eu já vejo que tem tal e tal paciente tudo junto, eu já fico cansada, a hora que eu vou pegar a pasta...(risos) Eu falo assim "não acredito, nossa, que vai tá tudo aqui, todos juntos" (risos)

(todos rindo)

Joana: É muito cansativo, estressante mas eles precisam de ajuda, mas é complicado pra gente.

Pesquisadora: E o que vocês acham que seria necessário para que vocês então se sentissem preparados?

Lia: Precisa de um curso, uma capacitação, alguma coisa.

Zulmira: Uma capacitação, é. Uma preparação, pra entender.

Joana: Acho que mensal, ou sei lá, tinha que ter algum grupo com a gente, com os profissionais... pra ta...né, fazer o tratamento em nós também, extravasar...Porque precisa...

Ana: Mas nós também vamos tratar como esses pacientes, no grupo a gente vai só conversar, mas na cidade tinha que ter o esporte, a cultura, a arte, pra eles poderem desenvolver sabe... E não fica só na conversa.

Joana: Não adianta só falar né.

Vanessa: Uma ocupação.

Lia: Eles precisam de ter um grupo pra ta participando...

Tatiana: Uma ocupação né.

Lia: E que gere renda pra eles.. na, mas deixa eu te contar uma experiência, a Vanessa conhece esse paciente mas ela não tava nesse dia. Tava eu e a Jack, nós fomos levar o Otacílio, a Helena, que é irmã do Otacílio e a D. Leila na saúde mental. Os três estavam surtados... Lá, era para internar D. Leila e eles não internam, tinha que sair daqui a regulação. E ela tava tão surtada que ela ficava assim "Lia, lia, lia... Pedro, Pedro, Pedro...Jack, Jack, Jack....” Ela brigou com todo mundo na Saúde Mental, a mulher queria colocar nós para fora, no final das contas a Dra que tava aqui regulou ela daqui, isso era 4 horas da tarde quando eles passaram pra pegar a gente lá. Nós saímos daqui 7 horas da manhã. Eu sei que no final das contas eu que fui pro Pronto Socorro, porque me deu uma crise de bronquite que eu quase morri lá...é complicado porque você pega a carga pra você deles. Deus me livre.

Joana: Por esse exemplo que a Lia deu, a Saúde Mental também sendo saúde mental, colocar eles pra fora, eles também não tão preparados.

Lia: Preparados...

Joana: O serviço não ta preparado.

Lia: O serviço social, lá de dentro, a mulher falou pra nós "Olha, se ninguém resolver eu vou colocar vocês pra fora" "Falei meu deus do céu, Jack do céu". Ai nós começamos a ligar sem parar aqui (na Unidade de Saúde). Aí a Dra Débora, você lembra Joana, que regulou a $\mathrm{D}$. Leila daqui e eles levaram o encaminhamento pra gente, pegou ela e internou ela na UE, então sabe é complicado porque na verdade eles não tinham com quem ir, e... A Helena brigando com a D. Leila, mas foi um "furdun"... já começou dentro da ambulância, a brigar, eu falei "Hoje vai ser feroz". Então, sabe...

Zulmira: Eu acho que o serviço social deixa a desejar, eles não se preocupam muito, pra resolver um problema demora muito também...Sabe, e a pessoa tem que humilhar muito também, a pessoa já tem um problema, ai chega lá tem que se humilhar, as vezes a pessoa 
fica pior ainda. Eu acho que o serviço social tem que ser um pouco mais unido. Até com a gente também, né, acho que tudo tem ser um conjunto. Eu to fazendo serviço social, eu tô tentando aposentar o Otacílio, nem tenho obrigação mas to fazendo por caridade, sabe, de ver a situação deles, tudo... Porque com um dinheirinho lá vai ficar tudo bem...não vai dar trabalho pra nós...

Ana: É até melhor pra gente.

Zulmira: Porque a Helena tendo dinheiro, o Otacílio tendo dinheiro eles ficam bem...Quando entra um dinheirinho pra eles, eles ficam bem... Talvez eu vou ficar pior (risos)...não sei...to tentando tipo assim... ajudar, vamos vê.

(silêncio)

Pesquisadora: E vocês já tiveram algum curso ou algum treinamento na área de saúde mental?

Lia: Não.

Joana: Eu a base foi na faculdade só.

Lia: Eu tive alguma coisa de saúde mental, alguma aula foi quando eu fiz o curso técnico. O que a gente aprendeu foi no dia a dia também.

Joana: É no dia a dia.

Lia: Nas visitas...

Vanessa: Mas como lidar com o problema não...

Pesquisadora: Então vocês acham que pela experiência, do dia a dia, vocês aprenderam um pouco, é isso?

Joana: Uhum...

Lia: Um pouco viu...

Joana: Acho que até bastante viu...

Zulmira: Mariana, você quer juntar a saúde mental com o PSF...Como você pretende implantar isso no PSF?

Pesquisadora: Então eu to querendo saber o que vocês acham disso primeiro. Eu to aqui pra ver o que vocês entendem pela saúde mental no trabalho de vocês.

Joana: Eu acho que aqui em Serra Azul tinha quer ter um ambulatório de saúde mental. Eu acho que nem o Dr falou, a gente do PSF tem que trabalhar antes pra que eles não venham a ficar doente

Ana: Com a prevenção né...

Joana: Com a prevenção né e ai a partir do momento que ele já ta com o problema mental, já ta doente mental, aí ele seria encaminhado pra esse ambulatório. Porque nossa é muito difícil.

Vanessa: Porque eu acho assim...

Joana: Porque aí vai ter a equipe toda preparada né...

Vanessa: Porque o PSF, nós, não tem como você tratar, implantar ali a saúde mental ali, mas assim, como o Dr falou, a prevenção sim, pra que eles não cheguem a doença, a surtar, mas não quando eles já estão, já é diagnosticado, teria que ter realmente esse ambulatório pra eles serem tratados lá e assim, a gente com parceria com eles, na fiscalização, nós agentes vendo se eles estão tomando a medicação, colaborando, mas não atuando diretamente, porque não tem como, nós não temos só saúde mental, nós temos outros grupos de prevenção, hipertensão, diabetes, gestante, criança... Então não tem como focar só nisso, por isso que tem que ter só o saúde mental e a gente com prevenção e ajuda. E isso a gente já faz no Círculo do Amor, o grupo que a gente tem com a fisioterapeuta que trata um pouco isso né... Depressão, o físico...e a mente, com Yoga né...

Ana: Massagens, relaxamento...

Vanessa: A pessoa aprendendo a se conhecer, até pra gente mesmo...

Ana: A lidar com as emoções no momento certo. Ela ta focalizando isso com a gente. 
Vanessa: As emoções...e amor né...

Joana: E além do mais eu acredito assim, que não depende só da gente entendeu, como já foi falado, eu acho que o município tem que estar se estruturando, porque não depende só de a gente vai lá e fala "É isso e isso e isso" Mas e aí, o que eles vão fazer... Tem problema social, não tem um esporte, não tem um lazer pra eles estarem indo.

Lia: Não tem um curso, não tem nada.

Joana: Então é complicado isso. O município tinha que ta estruturando também, alguma parte, esportiva... Pra eles estarem participando...( silencio) Não tem emprego... porque a gente vê que os que estão mais sofrendo mesmo é a falta de dinheiro mesmo...que tá levando eles a adoecerem.

João: Serra Azul tem outra característica, que o pessoal, é meio sazonal. Vem o pessoal que vai trabalhar no corte de cana, vem o pessoal que vai trabalhar no presídio. Aí traz a família, ai fica um tempo... então quer dizer, praticamente toda semana tem gente nova lá...

Lia: Tem.

João: "Ai porque eu vim do Piauí pra trabalhar no corte de cana" "Eu vim de Guarulhos porque meu marido trabalhava no presídio lá e foi transferido pra cá" "Ai eu vim porque minha família veio e agora eu vim pra cá".

Ana: "Eu vim porque meu marido ta preso"

João: Aí ficam com a gente um tempo e também vão embora. Do jeito que vem eles vão embora. E fica aquela coisa que nunca dá continuidade. $O$ pessoal da cidade, que são naturais daqui a gente já conhece, eu que to aqui há dois anos, conheço grande parte da nossa área, de vez em quando eu confundo né (risos)...alguns nomes, mas aí vira e mexe tem gente nova. Aí a gente vai perguntar "também não conheço, veio pra safra"... E traz os problemas de fora também...

Ana: Teve um que veio de São Paulo, surtou aqui, deu um trabalhão pra todo mundo, até pra achar ele, aí agora quando chegou o dia da consulta dele lá em Santa Rita ele foi embora de novo...Então... não deu pra tratar esse...

João: Isso é uma outra coisa que acontece aqui bastante...

Pesquisadora: Talvez isso dificulte o trabalho de vocês, de estabelecer um vinculo...

João: Mas isso também não é a maioria...Isso é uma parte, a maioria a gente faz tempo que ta aqui...mas é um fator...

Pesquisadora: E o que vocês acham de na reunião de vocês, do PSF, for discutido sobre Saúde mental, o que vocês acham disso?

Joana: Na nossa reunião a gente até discute, mas tem pontos que não cabe só a gente, que a gente precisa do tal do gestor e com o gestor...é...o problema é o contato...então...nunca senta com a gente pra ta falando...

Zulmira: Apoio também, que nunca dá...

Joana: Apoio... esse é o grande problema, porque assim...nós tamo fazendo o que a gente tá conseguindo, o que dá, mas apoio e contato com ele a gente não consegue, pra sentar e falar "vamos discutir hoje sobre isso isso e isso" Isso desde o começo que eles entraram nós não tivemos, não conseguimos...E já pedimos várias vezes reuniões...

Ana: O que eu vejo é que quem ajuda muito é a Joana, quando ela liga muito em Santa Rita, ela faz a regulação sabe...E as vezes lá embaixo, que teria que sair de lá não consegue, pede pra ela fazer...

Joana: É a gente sofre muito com isso mesmo, porque os pacientes chegam surtados aqui na Unidade e aí eles já pergunta de que área que é, a pessoa fala "Ai sou la do PSF 1" Aí taca lá pra gente, o paciente chega lá surtado, e o ambiente é pequeno,

Tatiana: Sem estrutura nenhuma... 
Joana: Sem estrutura e aí cabe a gente fazer a regulação pra não deixar o paciente ali... Ainda bem que agora a gente ta tendo Santa Rita né. Porque melhorou muito muito com essa pactuação, porque antigamente não tinha.

Zulmira: Tem psiquiatra agora aqui também né.

João: É tem psiquiatra.

Joana: Tem psiquiatra só que agora a lista de espera tá...

João: Aí a gente entra no quadro social, da carência né... Quando tinha oftalmologista todo mundo tinha problema oftalmológico, quando tem cardiologista todo mundo tem algum problema cardiológico. Quando tem psiquiatra vai todo mundo... E a gente também procura o que ta mais fácil pra nós...

Joana: $\mathrm{Eu}$ acho pouco sabe, pela situação que a gente tem. O município tem muitos problemas mentais e vim um psiquiatra uma vez por mês. Ta tapando buraco e não ta resolvendo nada.

Lia: Porque casos novos ta lá pra setembro.

Joana: Outubro.

Vanessa: E isso é uma área que não tem como esperar tanto tempo assim, tem que já começar a ser tratado.

Zulmira: O problema ta o seguinte, que um caso depende do outro. E fica tudo assim de mãos atadas, a gente não tem o que fazer. Eles também não faz nada, não tem ambulatório, não tem nada, fica assim ó. Fica um jogando pra cá, um jogando pra lá...

Joana: Aí aparece um caso a gente liga aqui (UMS), "Ai eu preciso agendar um caso, rápido com o psiquiatra" "Ai eu só tenho vaga pra outubro" "Ai mas não tem como encaixar" "Não, não tem". Aí é onde a gente socorre em Santa Rita, implora lá em Santa Rita e aí é onde eles estão ajudando...

Vanessa: Aí tem o problema de transporte...

Joana: É a estrutura do município...

Zulmira: Aí tem que ficar brigando com os motoristas também por causa do transporte.

Pesquisadora: E como vocês procedem quando percebem, ou na visita, ou no posto, um caso de saúde mental?

Marina: Ah dá pra perceber né, na hora você já percebe.

Zulmira: Na pré consulta mesmo, que eles já vão falando, já dá pra perceber.

João: Depende do estágio que ta isso aí.

Zulmira: E outra, as vezes parece que a Joana que é a psicóloga lá. O pessoal chega lá e fala "Preciso falar com você" Aí ela fala "Pode falar aqui" "Ah não vamos ali dentro" Ali... chora e chora..."To passando por isso e to passando por aquilo..." Ai a Joana conversa, conversa e pessoa sai bem. No outro dia parece que é o retorno "Ai Joana eu to bem, vim conversar com você de novo".

Joana: Ai isso vai cansando e a gente que não vai agüentando mais. E já não tem um ambiente adequado, né, não tem sala pra enfermeira lá.

Zulmira: Na pré-consulta o pessoal ta ali encima. Não tem nem como conversar direito também.

Lia: Mas nós na visita, geralmente a pessoa chega pra gente e pede pra falar com a gente, pra contar o problema dela entendeu, que ela ta passando ali dentro da casa dela, então fica mais fácil, a partir do momento que você já conhece a pessoa eles tem a liberdade de chegar pra você e contar o problema deles, eles acham assim, eu vou contar e ela vai tentar resolver meu problema, então fica bem mais fácil quando você tem um vínculo. Ai agora, aqueles casos que são mais complicados, como na nossa área lá, a família procurou, já tinha me falado várias vezes, eu falei "Do jeito que ele ta não é nós que vamos resolver, você vai ter que ir lá na Unidade, e levar ele, que o médico vai regular ele" Aí até que ela chegou lá né Joana, pediu, implorou, pelo amor de Deus. A Joana fez tudo que tinha que 
fazer, ligou lá, era pra ter levado o paciente, só que tinha que passar na Unidade pra pegar a cartinha porque o Dr não tava. O médico que tava de plantão olhou e falou que o paciente não tinha necessidade de ser internado... Aí fez uma medicação nele e mandou ele embora, aí ele ta até hoje aí. Só que ela já me procurou... Outro dia ela chegou lá "Cadê a Lia, cadê a Lia, tem que internar o Fulano" "ÊE Ê, eu não" Porque eu tenho medo entendeu, pelo que ele já fez...

Joana: As atitudes né.

Lia: É, as atitudes dele entendeu...Então...quem sou eu pra chegar lá na casa dela e pedir pro Homem internar...

Ana: A gente já até correu risco também com esse tipo de problema. Esquizofrênico né Joana? A gente chegou numa casa que a paciente também é esquizofrênica, na área da Marta. A Marta levava remédio pra ela todo dia, porque ela morava num cômodo, no fundo, e a família inteira saia pra trabalhar, a irmã dava remédio pra ela só que ela jogava fora, ai ela foi surtando, ficando mal, acho que no último estágio de loucura. Aí precisou de fazer um acompanhamento, ai eu e a Marta ia lá na casa dela todo dia, misturava o remédio ou no leite, ou na água né Marta? Amassetava o comprimido, que era muito duro e ela tomava...e ficava olhando ela tomar. Levava pão, café, pra ela poder tomar essa medicação. Aí um dia chegamos na casa dela pra fazer isso e o irmão dela também é esquizofrênicos, estava surtado, tava lá com ela, com uma barra de ferro dizendo que ia matar ela e quebrando a casa inteira. Aí a gente não sabia se chamava a polícia ou se entrava pra salvar ela...

Marta: Aí a gente entrou pra salvar ela...

Ana: Aí nós entramos lá correndo, pegamos ela, e saímos pra fora, chamamos a polícia e ele lá quebrando tudo, querendo bater em todo mundo...

Marta: Destruiu tudo a casinha dela...Mas a gente conseguiu uma grande coisa lá... Porque hoje a família dá remédio, leva ela na Saúde Mental...antes não levava...

Ana: É...

Marta: Reformou lá... Eles não davam remédio direito, não levava na Saúde Mental, aí eu comecei, levei um bom tempo lá na Saúde Mental... Hoje a família leva, a família dá remédio certinho...

João: Vocês quase apanharam...

(risos)

Ana: Foi o dia da Liga da Justiça

Marta: Mas você vê, os pacientes tem uma confiança muito grande. Nesse dias teve o casa do seu Jair, que ligou chamando a gente pra passar o caso...

Joana: Eles procuram...

João: Mas o primeiro contato são vocês...

Pesquisadora: Como que foi essa história do paciente que ligou?

Joana: Conta aí Marta.

Marta: Ele ta com problema o seu Jair, ele começa a ver vultos, escuta vozes, fala que o genro matou a filha...e...ele veio de São Paulo, tava internado, e a família não agüentava mais mandou pra cá né...

João: Ele é etilista né...pesado, bebia de mais...

Marta: É... bebia...e aqui passou pelo psiquiatra, ela passou medicação, mas... Ai com a medicação tava piorando, a família não tava agüentando mais... A filha me ligou né, falando que queria falar comigo, pedindo ajuda pra encaminhar.... Aí eu fui lá, ela passou o caso e eu passei pra Joana. Aí conseguiu levar ele em Santa Rita e hoje ele já está melhor.

Joana: Aí quando eu liguei pra Santa Rita ele pediram pra passar com um Neuro, e isso foi na sexta feira, aí no domingo a gente já conseguiu passar ele com o neuro, e na segunda ele foi pra Santa Rita também...Então foi uma ajuda muito grande pra eles... 
Zulmira: Ele não dormia, só falava...

Marta: Agora ele tem retorno lá em Santa Rita...Ele ta fazendo tomografia, pra trabalhar junto com o neuro.

Joana: Então eu acredito que o papel do PSF é muito importante nessas áreas, porque eles pedem nós estamos lá, parece o salva vida deles... Então a gente vai, corre, ajuda. Na Unidade Mista a gente vê que já é diferente, eles estão la pra resolver aquele problema momentâneo, e que as vezes acaba não resolvendo, porque quando tem PSF taca tudo pra gente. Então com a vinda do PSF melhorou muito, porque a gente cria o vínculo e muito com a população... porque tudo eles já sabem onde socorrer né...

Lia: Eles já sabem onde correr.

Marta: Onde pedir...

Zulmira: Por isso que era bom ter uma Saúde Mental, um Ambulatório aqui...Pra resolver, aí sim, não precisava ir pra Santa Rita.. Não precisava passar pelo motorista, pra poder levar...Já tava aqui...

Joana: Só nos casos de internação mesmo.

Vanessa: Porque como a gente conhece as famílias, todos né, nosso PSF já faz 11 anos que existe, então a gente já conhece... Já faz 8 anos que a equipe foi formada, que ta com a mesma equipe. A gente conhece eles, e sabe assim... quando agente vai visitar, pela história, a gente até comenta. A gente passa pra Joana, fala que acha que a pessoa ta entrando em depressão. Quem da o diagnostico é o Dr, mas a gente acaba tendo essa visão, pela experiência, é onde a gente encaminha, marca uma consulta com o Dr. Porque a gente já vai percebendo que a pessoa ta depressiva. Tem uma na minha área mesmo que ta com problema de saúde, teve câncer na mama, e eu já to percebendo que por esse história, fez a reconstrução da mama, não deu certo, e a auto-estima dela ta lá embaixo, a gente tem percebido conversando que ela ta entrando em depressão mesmo, então já precisa de ajuda, a gente já vai atrás pra ver se precisa de tomar uma medicação, pra ajudar, porque ela não toma. Pra ela superar isso e não ter problema mais sério. Então a gente acaba conhecendo e ajudando nessa parte o PSF.

Pesquisadora: Então, você está falando de identificar um problema de saúde mental, que você ta começando a perceber.

Vanessa: É. A gente acaba, pela experiência, por conhecer a pessoa, a gente... tem casos né, que a pessoa começa a demonstrar que ta ficando... não tá normal, não é o que era...que há alguma mudança e que pode ser algum problema como depressão ou não, as vezes só um problema momentâneo, familiar.

Ana: E quando a gente percebe a gente comenta, fala pra eles passarem com uma psicóloga, manda eles passarem com você, pergunta se não quer que a gente marque a consulta, que lá no PSF ta tendo agora né... E também pede pra eles entrarem no nosso grupo, no Círculo do Amor, que é onde trata isso também.

Vanessa: Mas é só pra mulher né...aí a gente convida...

(silencio)

Pesquisadora: E quais são os sentimentos que surgem quando vocês atendem, lidam com uma pessoa com um problema de saúde mental?

Lia: na verdade eu acho assim, quando você consegue fazer alguma coisa você sente um alivio que você conseguiu fazer alguma coisa, conseguiu resolver, mas quando você não consegue nada fica a frustração...

Tatiana: Não tem o que fazer...

Lia: É que assim, você não tem o que fazer e você fica assim...frustrada né...

Vanessa: Sabe que tem que ajudar mas...

Lia: Não tem como... 
Tatiana: Porque eles procuram muito a gente principalmente porque a gente dá atenção, a gente escuta né e eles acham que a gente vai poder ajudar, resolver tudo e a gente não tem estrutura, não tem como resolver e a vezes passa pra gente mesmo o problema...

Joana: E também tem aquela outra situação, que a gente faz, faz, eles tomam a medicação aí melhora para com a medicação...sem ter ordem médica pra estar parando... aí passa 1 mês, 2 meses eles voltam tudo com o mesmo problema. Aí você vai investigar eles falam "Ai eu tava bem parei com a medicação"...ai dá raiva, dá aquele sentimento

Lia: Dá raiva...

João: As vezes é paciente psiquiátrico, da saúde mental... é um paciente que acaba enchendo o saco da gente...É repetitivo, por isso que as vezes não dá certo, manda pro Caps eles vão no primeiro atendimento e não dão seqüência.. então é um paciente que demanda muito cuidado, muita atenção e as vezes você esta sobrecarregado, com 10, 15 pra você atender e ainda tem o pessoal que ta com problema que sabe que é alguma coisa mental, não tem quem te ajuda pra fazer tudo isso, ajuda seria organizar tudo isso. E aí ele volta, volta volta...e aí a gente tenta trabalhar do jeito que a gente consegue...

Ana: Parece que é uma coisa que não tem fim, não tem cura né...

João: Porque é crônico né, é uma coisa que vai ficar, você vai ter que dá atenção sempre sempre...mais dia menos dia vai voltar, pelo menos pra conversar...fazer alguma coisa e aí o pessoal abandona. Uma coisa muito é...um exemplo muito bom é aquele paciente que toma Fluoxetina, alguma coisa e no começo do uso a gente tem que fazer o uso de um benzodiazepínico pelo menos pra fazer dormir, ai fala "Ah, mas dormir é tão bom" Ele larga a medicação pra depressão mas ele quer usa o seu Diazepam. E o que tem de paciente aqui que a gente esqueceu de falar que faz uso abusivo de medicação, principalmente benzodiasepínico na cidade é absurdo. Isso aí já é um erro da minha classe. Isso é coisa de médico que prescreve as coisas pra... É aquela coisa emergencialista, "Toma e vai dormir". Então dormir é muito bom né, quem não gosta de dormir...E não é só o remédio, é o que a gente falou, se juntarem as duas coisas não vai melhorar... Então o pessoal tem uso abusivo de medicação, isso que eu tava lembrando agora.

Vanessa: E ai teve que caso até que houve a morte por conta disso...

João: E tem gente que chega pedindo Lorax, Rivotril, Diazepan..E é assim e toma... Porque é assim, vai num médico ele receita o Diazepan, vai em outro que receita outro... Porque é assim, não tem contato, quando a gente tem... A Zulmira briga comigo direto, "Ai Dr mas não vai dar?" Não vi dar, o cara toma, por que toma? Tomava a 4 ou 5 anos atrás e quer tomar de novo, não passou por uma avaliação, ai já entra o problema da estrutura toda e ai vira um monstro...

Tatiana: E tem paciente que gosta tanto dessas medicações que ele já receita pra outro né...Pro marido...

João: Tem uns que tomam, que precisariam de uma terapia, com psicólogo e falam "Ai não, não preciso não, o remédio funciona, eu sei que funciona"

Ana: Nós fomos fazer visita né, um paciente da Marta, é tudo da área da Marta, a senhora ela é viciada no Diazepam, toma todo dia, briga com a gente quando o Diazepam dela acaba e ela quer mais receita né, e ai ela falou assim que na casa dela ela tomava Diazepam só que ela colocava no suco, dava pro marido, pros filhos, pros netos para eles dormirem e da sossego pra ela durante o dia.

Marta: É a estrutura da família sabe, o filho usa droga, tem problema mental...

Ana: Ela fala que quer descansar deles...

Zulmira: E ela é crente, ora a Deus e ta tudo bem...

(risos)

Joana: A saúde mental dela é o Diazepam.

(risos) 
João: E aí entra a mesma história da prevenção lá atrás, se a gente tivesse como conversar, explicar o que acontece....se evitar 4 ou 5 já ajuda bastante...

Lia: $O$ duro é aquele que já ta lá com o vício...

João: mas aí vocês falam do Círculo do Amor... Umas pacientes eu tenho certeza que já... acho que 2 ou 3, que pararam de usar a medicação com o auxílio de outra forma...

Ana: A gente tem que fazer um gráfico e colocar tudo isso no papel...

Zulmira: Oh, tem uma paciente que ela tinha uma dor terrível no joelho, terrível, ia la direto, fez ressonância e nada... Ai começou a fazer o Círculo do Amor, parou a dor no joelho dela... Aí parou de ir no Círculo do Amor, aí ontem ela foi la marcar consulta porque voltou a dor no joelho dela...

João: Então você já escreve lá que eu vou falar pra ela voltar...

Vanessa: Eu passei lá na casa dela ontem, perguntei porque ela não foi no Círculo do Amor, ela disse que foi la marcar uma consulta e eu falei que tinha que ter ido lá no Círculo...

Ana: E a maioria dessas mulheres que estão participando do Círculo, elas saem mais dispostas, toda vez que termina a aula elas saem mais alegre, sabe...

Zulmira: Então, se tivesse um ambulatório aqui, se tivesse assim um contato todo dia, psiquiatra, psicólogo, PSF, médicos e gestor, eu acho que tudo funcionava...

Vanessa: Porque a gente ta por dentro dos casos, né...

Zulmira: Ta por dentro...se precisasse de alguma coisa a assistente social tava ali, se precisasse encaminhar pra algum psiquiatra o médico já estava ali...Então é esse conjunto que eu acho que tá faltando... e um lugar pra ter um ambulatório aqui, não exatamente no PSF, mas em outro lugar...

(risos)

Mas que tudo tivesse interligado um ao outro...

Vanessa: Que fizesse uma reunião pelo menos quinzenal...

Zulmira: Trabalhar todo mundo em conjunto...nao vim ao 1 vez no mês, aí não dá, tinha que ter já aqui né, acho que é isso que ta faltando, a gente faz a nossa parte, mas não tem quem faz a outra parte...Mas também o gestor né...as vezes a gente quer conversar, passar alguma coisa, nem lá ele vai...

Pesquisadora: Vocês não tem uma conversa com o pessoal da Unidade Mista?

Zulmira: Não, ali ninguém tem dialogo com ninguém...por isso que as coisas não funcionam...

Joana: O único contato que a gente tem é quando dá algum problema que a Enfermeira de lá liga, ou quando eu preciso eu ligo pra ela, é o único contato que a gente tem, quando a coisa já ta assim, estourando...Que precisa resolver momentaneamente..ou então é com o Gerente da Unidade, que a gente passa o que precisa, mas com o Gestor mesmo não...

(silêncio)

Pesquisadora: Vocês gostariam de falar mais alguma coisa, que vocês pensaram, que surgiu agora...

(silêncio)

Pesquisadora: O que vocês acharam dessa nossa conversa?

Zulmira: Acho que a gente pensa tudo igual...

(risos)

Joana: Foi mais um desabafo...

Lia: É foi um desabafo...

Tatiana: O ponto principal é esse, a falta de estrutura, desde a família até no município, tudo ta faltando..tudo...

João: Acho que é a prevenção.. estatisticamente falando, depressão acho que vai ser a doença mais... 
Lia: Já está sendo

João: Mas dizem que num futuro próximo vai ser a doença crônica mais prevalente na população, se a gente não tratar antes de chegar nisso só remédio não vai dar certo...

Lia: Não vai dar...

Vanessa: É porque se já ta na estatística isso, né, que a gente já vê, já percebe realmente, acho que todos tem que se unir, não só o nosso município, mas desde lá, um projeto, alguma coisa, uma prevenção, capacitando os funcionários da saúde em geral, do país pra que venham atuar nessa área...de transtornos mentais, saúde mental....pra que trabalhe a mente...

Zulmira: Acho que teria que ter igual a Célia fazia, uma terapia ocupacional, convidar essas pessoas que tem depressão, que tem alguma coisa pra ta ali, sabe, no dia a dia, fazendo alguma coisa pra esquecer os problemas também...Só que ela tinha com quem contar, precisava comprar alguma coisa, ela tinha, hoje é uma burocracia tremenda, pra entrar aqui dentro, tivemos até que pedir licença pra recepcionista, pra poder entrar...não tem mais aquela ligação.. lá pra comprar um café, um botijão de gás, nossa é uma coisa...nossa senhora...

Lia: Eu acho que teria que ta tudo interligado, cultua, social, esporte, tudo...a saúde, tudo interligado pra poder desenvolver algum projeto, pra eles terem uma ocupação...

Vanessa: Ficou de formar o grupo da hidroginástica né, e nada, ta parado... Projetos existem, só que esses projetos não são realizados, não tem o desenvolvimento deles na prática...

Lia: Se tivesse muitas pessoas já estariam bem melhores..

Vanessa: Muitas barreiras...

(silêncio)

Joana: Também antigamente o social eles colaboravam mais, tinha curso de fazer rede, de pintura, então o pessoal participava, mas agora não tem esse contato, liga quando precisa resolver a situação momentânea...

Vanessa: Hoje até tem os cursos, mas acho que tinha que ta passando pra nós, né.. pra gente ta informada pra avisar as pessoas, porque são sempre as mesmas que vão fazer os cursos..porque as vagas são limitadas, então não tem espaço pra outras pessoas, são sempre os mesmos, termina um e começa o outro, porque só eles sabem...Eles tão até desenvolvendo aula de pintura, mas sempre são as mesmas pessoas que estão ali...

Lia: As inscrições não são divulgadas, não tem um espaço ligado aqui com gente, pra gente ta divulgando, estimulando, orientando pessoas que realmente precisam...

Ana: Mas eu tenho prestado atenção, tem pessoas que precisam na minha área, tem uma mesmo que precisa, a gente conversa, fala, mas parece que não quer se ajudar, num faz um esforço, uma pessoa prostrada, ta vendo que ta precisando, vamos fazer alguma coisa, ai fala que queria mas sabe quando parece que não tem coragem de sair da própria casa pra fazer alguma coisa pro bem estar...várias pessoas parecem que são desse jeito aqui em Será Azul...

Vanessa: São acomodados...

Ana: Pra tudo...

João: Isso é geral...

Ana: não sei o que pode fazer, e elas querem remédio, quer dormir...e não quer se ajudar... (silêncio)

Joana: Acho que é isso né...

Lia: Acho que sim... Espero que a gente tenha ajudado.

Pesquisadora: Gostaria de agradecer, acho que a discussão foi muito rica...Muito obrigada.

Joana: Acho que esse tipo de reunião a gente tinha que ter quinzenal... 